
$\eta 7 A$

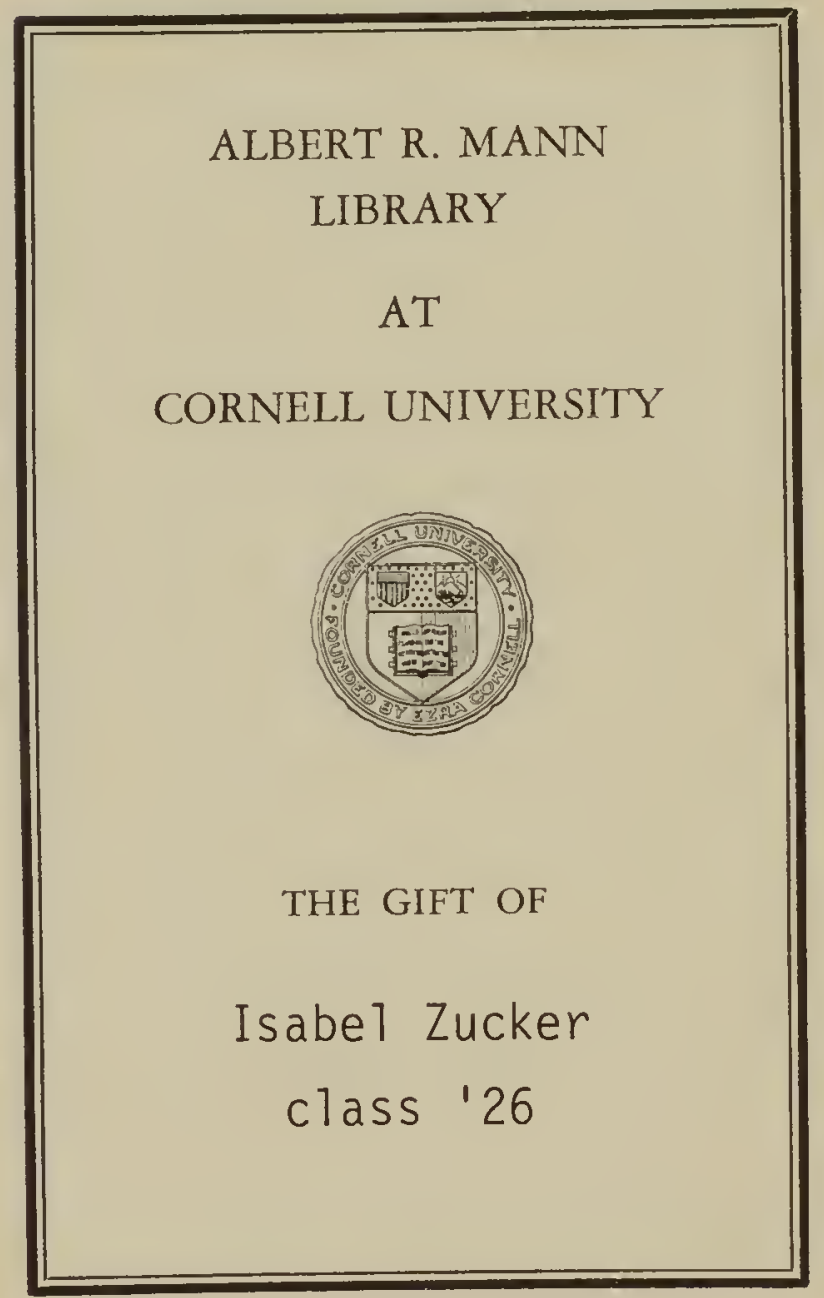



FLORAL EMBLENS. 
LONDON:
Pristine, Savor Stream, strand. 


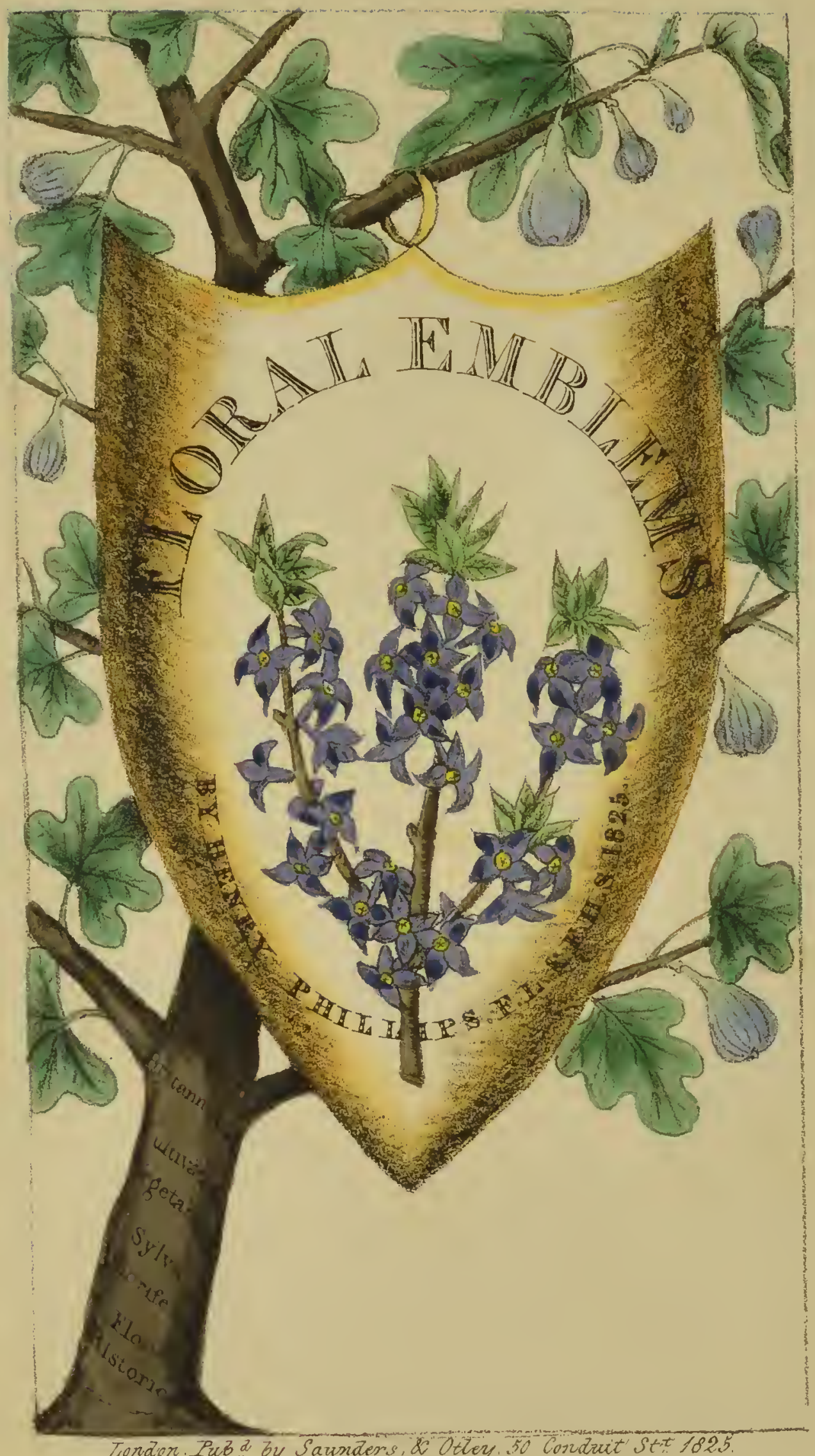




\title{
FLORAL EMBLEMS
}

or

\author{
A GUIDE
}

TO THE

\section{LANGUAGE OF FLOWERS}

NEW EDITION

BY HENRY PHILLIPS, F. L. \& F. H. S. AUTHOR OF POMARIUM BRITANNICUM, \&c. \&c.

\section{LONDON}

SAUNDERS AND OTLEY, CONDUIT STREET 1831 


$$
\begin{gathered}
\text { VAULT } \\
\text { GR } \\
780 \\
P 56 \\
F 6 \\
1831
\end{gathered}
$$

$$
7716 \cdot m^{98}
$$




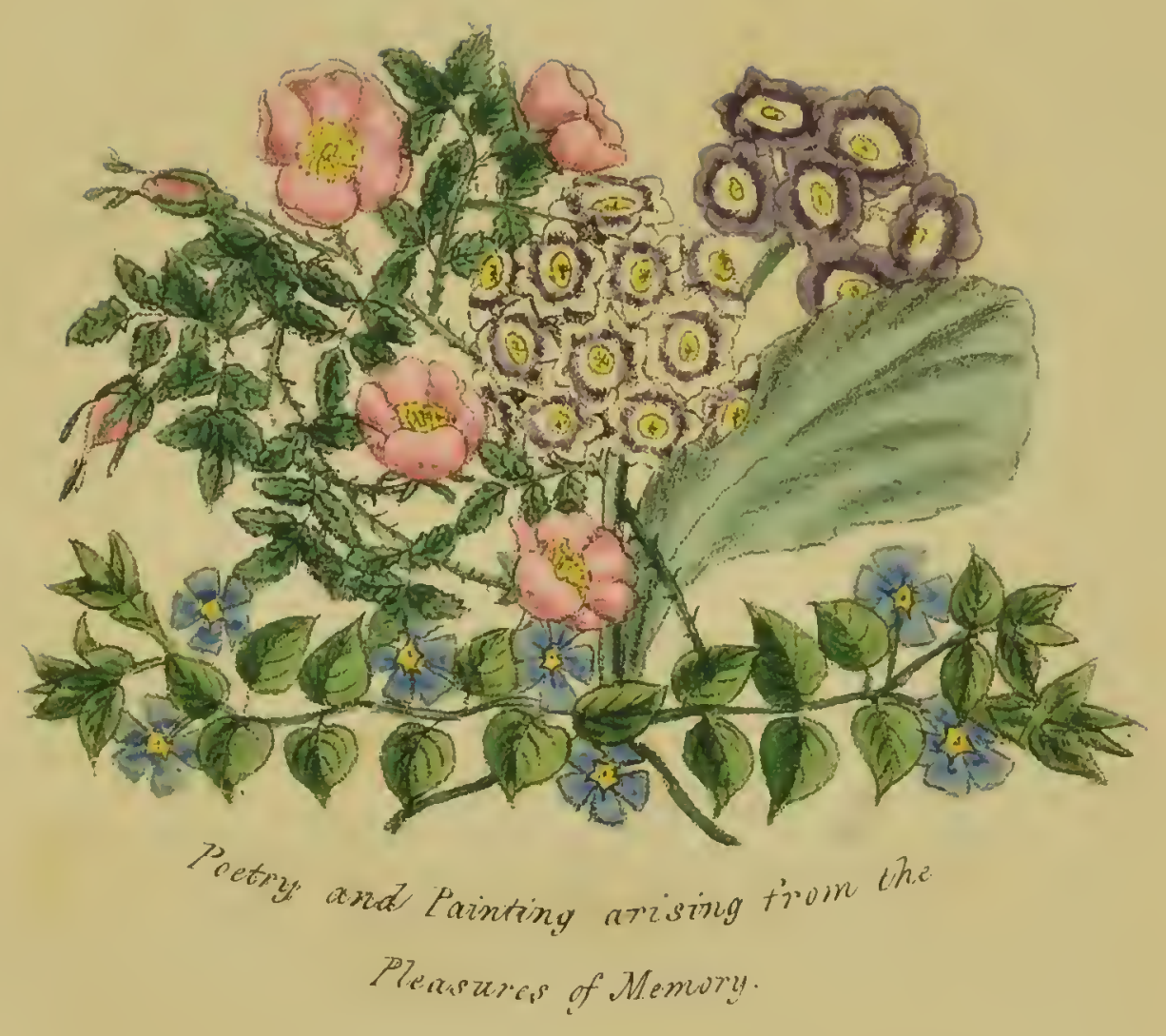

TO THE POETS AND PAIN'TERS

. $\mathrm{OF}$

\section{Great Litain,}

Whose Works have so eminently contributed to raise the fame of these kingdoms above the level of that of any other nation in modern times, the author most respectfully presumes to dedicate this collection of "Floral Emblems," as an humble acknowledgment of the great delight their performances have afforded him from the earliest period of his memory, to the time he has the honour of subscribing himself,

Their most devoted admirer,

And humble Servant,

HENRY PHILLIPS.

Brighton, May 28, 1825. 



\section{PREFACE.}

IN forming this collection of Floral Emblems, the first care was to avoid perplexity, by creating new symbols, with such flowers as have been previously used in the hieroglyphics of the ancients or described in the verses of the poets.

Therefore, when the compiler found the same plant made to represent more than one design, he selected the emblem of the greatest antiquity, or the one most established by custom, and in some instances he has noticed their various interpretations. 
Amongst the numerous species of plants which Europe has received from China, America, and New Holland, but few have hitherto found their way into the language of flowers, and some of these he has ventured to present, as emblematical of such characters or passions, as appeared most appropriate.

The numerical emblems, as well as those for the days of the week, and the months of the year, were devised by him in order to render the work more complete, so as to enable the emblematists to record dates by floral symbols.

As the invention of symbolical language appears to have originated in eastern nations, the author's endeavours have been to collect the emblems of those countries, through the aid of their poets, and the assistance of various travellers.

The most ancient works on heraldry have 
been consulted as well as the sculpture of classical nations and the paintings of modern ages. . The assistance of the poets will be seen in every page, and it would be unjust not to mention the author's obligation to Madame la Comptesse de Genlis, to Madame de Latour and also to the author of "Parterre de Flore." In this symbolical assemblage the author has carefully avoided all indelicate allusions or double-entendre that could be offensive to modesty, his object has been to establish a settled collection of floral emblems, and to render them as amusing as the decorative dress of the poet, and the sparkling garb of the wit would allow. And although he presents a flower to fit every cap, none are personally intended, but the whole are offered for the selection of the wearer, and should weeds be discovered where flowers are expected, he flatters himself they will be few, and that those few will be found inoffensive, for although the work may be considered more adapted for amusement than for utility, he would not willingly offer en- 
tertainment through the assistance of immorality.

The author trusts that his work will not be condemned because it allows a communication of sentiment.

"By all those token flowers, that tell What words can never speak so well."

Byron.

It is observed by Lady Mary Wortley Montagu, that in Turkey, you may through the assistance of these emblems, either quarrel, reproach, or send letters of passion, friendship, or civility, or even news, without ever inking your fingers, for she says, there is no colour, no weed, no flower, no fruit, herb, nor feather, that has not a verse belonging to it.

When a Turkish lady sends a congratulatory message, or a ceremonious invitation, it is generally accompanied with some emble- 
matical flowers carefully wrapt up in an embroidered handkerchief. The freshness of these flowers show the speed of the messenger, whilst the selection speaks in silent language the sentiments of the party from whom they are sent, and whose rank is also distinguished by the costliness or beauty of the embroidered envelop. These are merely the remains of the ancient customs of the eastern nations, where all was symbol, emblem, and allegory, and it must not be supposed that emblems were invented for the purposes of intrigue, since we find the scriptures full of the most beautiful parables, moral symbols, instructive allegories, and poetical emblems, that have ever been composed or collected.

It is presumed that the introduction of a few continental garlands in their native garb, will be found both agreeable to the taste of our readers, and in harmony with the subject of the work. With this expectation we present the following French wreaths of floral verse. 


\section{LA BOUQUETIERE.}

J'ai des bouquets pour tous les goûts ;

Venez choisir dans ma corbeille;

De plusieurs les parfums sont doux;

De tous, la vertu sans pareille.

J'ai des soucis, pour les jaloux ;

La rose, pour l'amant fidèle;

De l'ellébore, pour les fous;

Et pour l'amitié, l'immortelle.

J'offre la pensée aux auteurs;

(Les leurs, bien souvent sont si fades.)

Des tournesols, aux vils flatteurs; ;

A tous nos braves, des grenades.

Pour les argus, j'ai des pavots,

Et pour les enfans, des clochettes;

J'offre des œillets d'inde aux sots;

De la fleur d'orange, aux coquettes.

Pour l'homme timide et discret

J'ai la modeste violette;

J'ai le narcisse et le muguet,

Pour le fat et pour la coquette 
J'offre le myrte aux vrais amans;

Aux maris jaloux, des jonquilles;

Des mignardises, aux mamans;

Et du thym frais, aux vieilles filles.

Je réserve pour la pudeur

La délicate sensitive;

L'oreille d'ours à la laideur;

Des simples, à l'agnès naïve;

A la veuve dans les regrets

Mes scabieuses doivent plaire;

$J$ 'ai des couronnes de bluets

Pour la jeune et fraiche bergère.

J'offre aux filles à marier

L'iris, emblème d'espérance ;

A tous nos héros, le laurier;

Les boutons d'or, à l'opulence;

Les tulipes, à la fierté;

Aux malheureux, la patience;

La fleur d'hortense, à la beauté

Et tous nos lis, à l'innocence. 


\section{LE LANGAGE DES FLEURS.}

Fiore n'est point embarrassée,

Quand la beauté lui fait la cour;

Adèle choisitla pensée,

Pour exprimer son tendre anıur ;

De Malvina, modeste et sage,

L'humble violette est la fleur';

Et Zulima, triste et sauvage,

Du souci porte la couleur.

L'inconstante et folle Rosine

Prend les nuances de l'Iris ;

La sensible et douce Delphine

Prefère le bel Adonis ;

Auprès d'une tige de Lierre,

On voit la fidèle Nina;

Et sur un tapis de Fougère

Repose la tendre Zulima.

Ainsi dans cette galerie,

Chaque belle offrant un bouquet, Maint savant peut passer sa vie

A méditer chaque sujet. 
PREFACL.

Heurenx l'aimable botaniste

Qui sait jouir de ces douceurs!

Pour un galant naturaliste

Toutes les femmes sont des fleurs.

A. I) reville. 


\section{LA CORBEILLE DE FLEURS.}

Par un mystérieux langage

Ces fleurs t'apprennent mon amour;

Eglé, je t'en offre l'image

Dans ce lis, pur comme un beau jour.

Cette violette naissante

T'exprime ma timide ardeur,

Et la grenade eblouissante,

Les feux qui consument mon cœur.

L'immortelle peint ma coustance;

La jonquille, tous mes ennuis;

Le myrte, ma douce espérance;

Et le souci, tous mes soucis.

Reine des fleurs, suave rose,

Heureux symbole du plaisir,

Parle pour moi : ma bouche n'ose

Exprimer le moindre désir.

Rose, sur le sein de ma belle

Brille à mon regard enchanté,

Et sois le présage fidèle

De ma douce félicité. 


\section{LES FLEURS.}

Suis-je dans un joli jardin,

J'en parcours tonjours le parterre,

Et dans les fleurs je crois, soudain,

Distinguer chaque caractère ;

Dans la violette, je vois

La séduisante modestie;

L'immortelle m'offre, à-la-fois,

Et les vertus, et le génie.

Dans le Muguet, je vois un fat,

Dans le Serpolet, la franchise ;

La Tulipe, avec son éclat,

M'offre l'orgueil et la sottise ;

Le Lis presente la grandeur;

L'Amaranthe, l'indifférence ;

Rose blanche, dans sa fraîcheur,

Est l'image de l'innocence.

Le Pavot nous peint le pouvoir

Que, sur nos sens, a maint ouvrage;

Dans le Narcisse, je crois voir

Un sot épris de son visage; 
Dans le Souci, je reconnais

L'époux d'une femme infidc̀le;

Dans une Rose, les attraits.

Qu'on admire dans une belle.

Te Myrte, chéri des amours,

Nous représente leur prissance;

Et le Lierre, amoureux toujours,

Donne des leçons de constance.

si je m'arrête au fond d'un bois,

Avec [ris sur la follgère,

La Fougère m'offre à-la-fois

Mon lit, ma bouteille et mon verre.

Puis-je rencontrer des Lauriers, Sans m'arrêter et reconnaître

Ces jeunes et vaillans guerriers

Que l'heureuse France a vu naitre!

$\mathrm{Si}$ je rois l'Olivier fleurir,

Sur-tout après un long orage,

Je dis: la paix va revenir,

La paix est le prix du comrage.

P. Ledomx. 

Endblemancall Ewer of Britain, with the Symbal of Mris . Majesty's Birth-Day

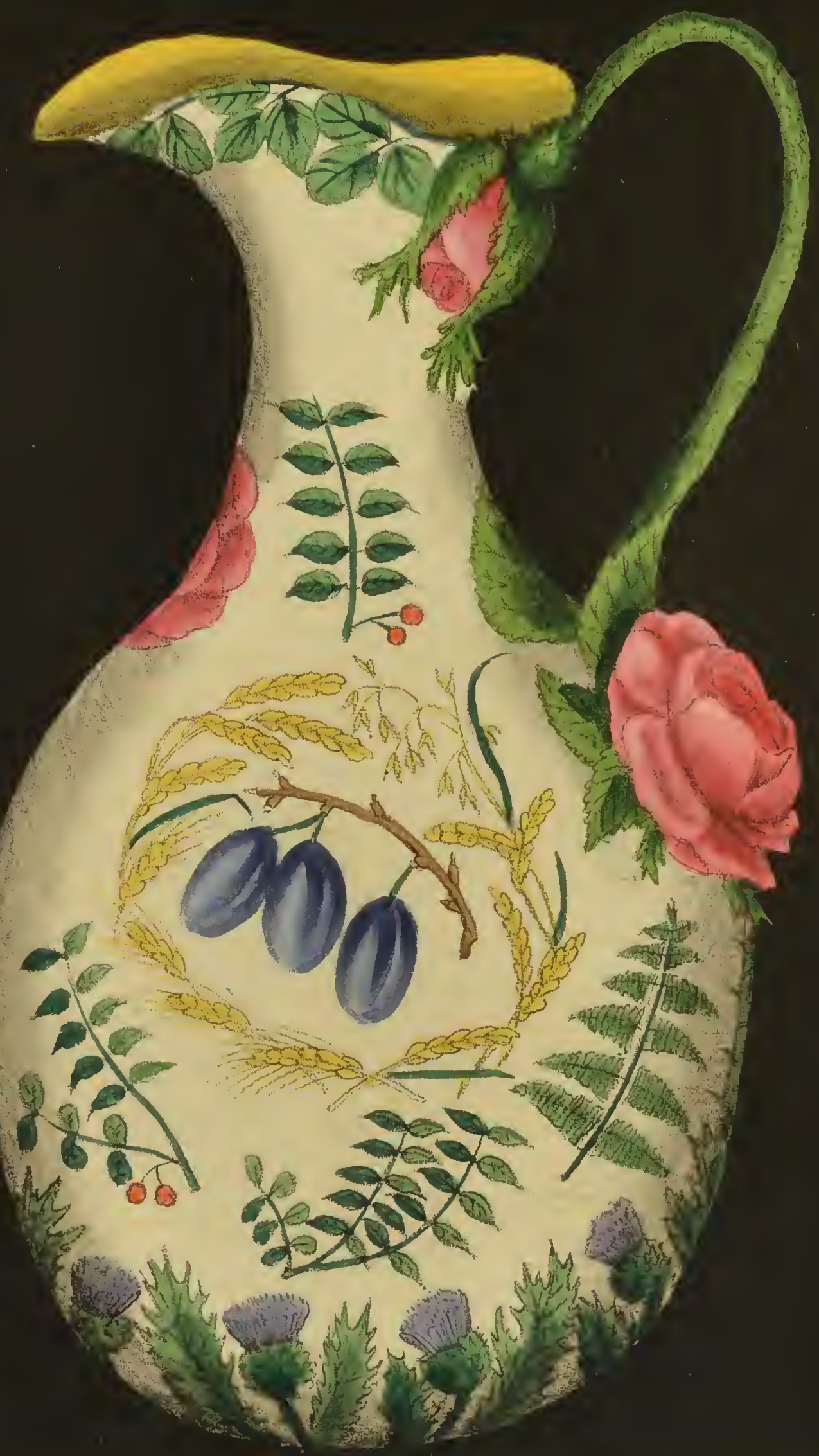




\section{INTRODUCTION.}

"With emblematick skill and mystick order,

Thou shew'dst where tow'rs on battlements should rise, Where gates should open, or where walls should compass."

Prior.

Tнат hieroglyphics formed the earliest kind of written language cannot be disputed, since reason pronounces pictorial emblems the most natural mode by which a communication of ideas could be effected previous to the invention of a more regular system.

The monuments of the greatest antiquity confirm this opinion, and the most ancient rocks of Egypt make known the early conquests of these people which are expressed 
by the representation of vegetables that are foreign to their climate.

Brown says in his Pseudodoxia Epidemica, " that of all men that suffered from the confusion of Babel, the Egyptians found the best evasion; for, though words were confounded, they invented a language of things, and spake unto each other by common notions in nature, whereby they discoursed in silence, and were intuitively understood from the theory of their expressions : for they assumed the shapes of animals common unto all eyes, and by their conjunctions and compositions were able to communicate their conceptions unto any that comprehended the syntaxis of their natures."

The labours of M. Champollion in deciphering the ancient Egyptian Papyri at the Royal Museum at Turin, have proved this emblematical writing to have existed prior to the days of the Pharaohs. 
These records are all written in hieroglyphics, and ornamented with paintings, and are in the most beautiful style of caligraphy. Several of these papyri are more than three thousand years old.

The hieratic writings of the Egyptians related to sacred or ecclesiastical affairs, and are principally found in the funeral rituals of the Mummeys.

The invention of emblematical writing evidently took its rise from nature and necessity, more than from choice or artifice, as is proved by its being practised not only by the Egyptians of the south, the Scythians of the north, the Chinese of the east, the Indians, Phœnicians and Ethiopians, of the intermediate countries, but also by the Mexicans of the west. For when Mexico was discovered, the inhabitants were found to have made no farther progress in the art of writing their laws and history, than what could be de- 
scribed by pictures. Robertson relates that in an interview which Cortes had with the Mexican chiefs, the latter were attended by painters, who employed themselves diligently in delineating upon white cotton cloths, figures of the ships, the horses, the artillery, the soldiers, and whatever else attracted their eyes, as singular, in order to convey to the mind of Montezuma, their sovereign, a more lively idea of the strange and wonderful objects now presented to their view, than any words could communicate.

Even at the present day, when written language is so copious, we should be unable to describe a rose to those who had never seen such a flower, without the assistance of drawing something similar. When the camellia japonica was first brought to flower in this country, we felt it impossible to give a just idea of the flower without drawing a picture in language, by representing it like a rose formed by wax and placed on a branch of the 
Portugal laurel; had the rose and the laurel been unknown, nothing short of a drawing could have described this beautiful plant. In all works of natural history drawings are essential to convey an adequate opinion of the thing wished to be described. And volumes cannot convey to our mind so just an idea of a country, a city, or a single building, as is learnt by one glance of a pictorial representation. To impress a just conception of the persons, habits, and manners, of a strange country without the aid of picture, we might as well try to give the true relish and taste of the pine-apple by words.

To shew how appropriately the ancients chose their emblems, we have only to mention that rotundity was the figure by which they expressed eternity, because it has neither beginning nor end. And this symbol was frequently represented by a serpent bent into the form of a circle, with its tail placed in its mouth. The cock was the emblem of vigilance, the lion of strength, the horse of liberty, 
the bullock of agriculture, the bee of industry. The spider was symbolical of the art of weaving, the sphinx became the emblem of subtility, a crocodile represented the land of Egypt, and a merchant was described by a man holding a purse.

The hierogrammatists, or holy registers who had the care of the sacred hieroglyphics in Egypt, made use of symbols only known to themselves. They were always near the person of the king, and they bore a kind of sceptre in the form of a ploughshare. But after Egypt became a Roman province, these offices sunk into neglect, and the phœnix, their hieroglyphic of the sun, set to rise no more in their symbolical writings. In the height of Egyptian prosperity, moral reflections as well as public events were represented by pictures, as is shewn by the celebrated inscription on the temple of Minerva at Sais, where an infant, an old man, a hawk, a fish, and a riverhorse, are made to express this sentence: 
"All you who come into the world and go out of it know this, that the gods hate impudence."

"Between the statues obelisks were plac'd, And the learned walls with hieroylyphics grac'd."

In the hieroglyphics of Harapollo two armies in battle array are represented by two hands, one holding a shield, and the other a bow.

Trismegistus, the celebrated Egyptian priest and philosopher, is said to have been the first who taught his countrymen the art of recording memorable events by this kind of symbolical writing; perhaps he only improved upon it by substituting signs which connected pictures and characters, and formed regular grammatical sentences, as the Egyptians seem to have been the first who made this advance in the science.

The Chinese appear to have thrown out 
the images altogether, and to have kept only the contracted marks which serve for words; yet we are told that they retain an alphabet composed entirely of plants and roots.

The gods of the early heathen nations originated from emblematical representations of illustrious personages who had benefited mankind either by their abilities in the arts, by defending their country, obtaining conquests, or establishing equitable laws. Thus Mars is represented by his armour, Hercules by his club and the lion's skin, Neptune by his trident, Ceres by a handful of corn, Bacchus by clusters of grapes, Pomona by apples, Flora by flowers, \&c. Even the barbarous Scandinavians adorned their goddess Frea, with emblems of fertility and abundance as the deity of marriage.

The language of flowers is said to be as old as the world, and the antiquity of floral emblems as great as that of love itself, and by 
whom it is supposed to have been invented, since it is a kind of parable which speaks to the eye, and through that medium is transmitted to the heart.

That love reigned in the breast before the hand had practised the art of forming hieroglyphics cannot be doubted, and that man should select the most beautiful objects in nature to represent his most ardent passion is equally probable. We may conclude that the bower of myrtle and roses was the earliest temple dedicated to love and beauty, and that to this happy spot the youth invited his spouse by means of floral emblems.

Milton thus pictures the first parents of mankind :

"Hand in hand alone they pass'd

On to their blissful bow'r : it was a place

Chos'n by the sovereign planter, when he fram'd

All things to man's delightful use; the roof

Of thickest covert was inwoven shade,

Laurel and myrtle, and what higher grew 
Of firm and fragrant leaf; on either side Acanthus, and each odorous bushy shrub,

Fenc'd up the verdant wall ; each beauteous flower, Iris all hues, roses and jessamine,

Rear'd high their flourished heads between, and wrought

Mosaick; underfoot the violet,

Crocus, and hyacinth, with rich inlay,

Broider'd the ground, more colour'd than with stone

Of costliest emblem."

The ancient and silent language of flowers lends its aid to gratitude, friendship, filial love, and maternal fondness. Even affliction may be soothed by the emblematical communication of sentiment. Roucher, when imprisoned by the tyrants of the revolutionary tribunal of France, amused himself by the study of floral language, his daughter being allowed to send him flowers to the prison. Thence a few days before he met his fate on the scaffold, he sent back to this favourite child, two dried lilies, to express both the purity of his heart, and the fate which awaited him. 
Sadi the Persian poet, when a slave, presented a rose to his lord with this pathetic accompaniment: "do good to thy servant whilst thou hast the power, for the season of power is often as transient as the duration of this beautiful flower." The heart could not resist what was so forcibly communicated by the ear and the eye, and Sadi consequently obtained his freedom.

The Eastern nations not only used emblems in writing, but they also expressed themselves by figurative language in conversation. Thus we find in Scripture that the "harvest" or " the reaping of the earth," was symbolical of the gathering in of the Jewish people, and the "vintage" the symbol of judgment.

Heraldry is nothing more than a pictorial style of writing the achievements of men, which was better adapted to the age in which it originated than a more mysterious style, since even the most illiterate could conceive 
the meaning of such a display, for painting is an universal language that all countries equally understand. “Painters," says Browne, "are the visible representers of things, and such as by the learned sense of the eye endeavour to inform the understanding."

When the Israelites were divided into twelve tribes, their great lawgiver affixed to each a certain emblem or device as a peculiar mark, by which they were to be distinguished, and these were arranged according to the prophetic blessing of the patriarch Jacob.

The shields of the Greek heroes, described by Homer, Eschylus, and Virgil, were nothing more than symbolical emblems allusive to past exploits or predicted achievements, as were also the reverses of their medals and coins.

In the early days of our own history we find the rudest symbols were sufficient to 
answer the purpose of distinguishing one man, or band of men, from another. The Scottish clans were generally particularised by the pattern or colours of their tartan plaid.

But this was found insufficient without the aid of floral emblems, and they therefore adopted the plan of ornamenting their bonnets or helmets with a sprig or branch of a plant as a symbolical badge of their various bodies. This ancient custom was again revived when his majesty visited his northern capital in he year 1822. His loyal Scottish subjects on that joyful event, paid their respects to their sovereign, at the palace of Holyrood House, each wearing the heraldic emblem of his clan. And as it may be interesting to their southern friends to know these symbols of the Scotch families, we have added a list of such as appeared at the royal court at Edinburgh on this occasion, to which we add the Gaulic and Scottish names of the plants, as well as that of the English and generic definitions. 
Highland clans. Gaulis. Scottish. English. Classical.

\begin{tabular}{|c|c|c|c|c|}
\hline Buchanan & Am beatha & Birk & Birch & Betula \\
\hline Cameron & An darach & & Oak & Quercus \\
\hline Campbell & Roid & Gaul & Myrtle & Myrica \\
\hline Chisholm & Am fearna & Eller & Alder & Alnus \\
\hline Colquhoun & An Calltain & $\longrightarrow$ & Hazel & Corylus \\
\hline Cumming & Seileach & Sough & Sallow & Sulix caprea \\
\hline Drummond & An cuil-fhionn & & Holly & Ilex aquifolina \\
\hline Farquharson & Meuran-fith & - & $\begin{array}{l}\text { Purple fox- } \\
\text { glove }\end{array}$ & Digitalis \\
\hline Ferguson & - & & Poplar & Populus alba \\
\hline Forbes & Bealaidh & & Broom & $\begin{array}{l}\text { Spartium sco- } \\
\text { pariam }\end{array}$ \\
\hline Frazer & An $t$ iudhar & & Yew & Taxus \\
\hline Gordon & $\begin{array}{l}\text { Eidhionn-na- } \\
\text { craige }\end{array}$ & & Ivy & Hederu \\
\hline Graham & 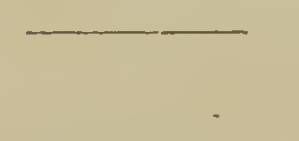 & & $\begin{array}{l}\text { Spurge lau- } \\
\text { rel }\end{array}$ & $\begin{array}{l}\text { Daphne laur- } \\
\text { eola }\end{array}$ \\
\hline Grant & Mùileag & & $\begin{array}{l}\text { Cranberry- } \\
\text { heath }\end{array}$ & $\begin{array}{l}\text { Vaccinium ox } \\
\text { yeorlos }\end{array}$ \\
\hline Gunn & Lus-nan-laogh & 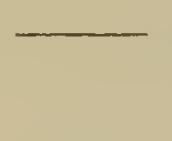 & Rosewort & $\begin{array}{c}\text { Rhodiola } \\
\text { rosea }\end{array}$ \\
\hline Lamont & $\begin{array}{l}\text { Abhal-fiad- } \\
\text { haich }\end{array}$ & & $\begin{array}{l}\text { Crab-apple } \\
\text { tree }\end{array}$ & Pyrus malus \\
\hline M'Allister & Fraoch & Hather & $\begin{array}{l}\text { Five leaved } \\
\text { heath }\end{array}$ & Erica cinerea \\
\hline M`Donald & $\begin{array}{l}\text { Curachd-na- } \\
\text { cu'aig }\end{array}$ & $\longrightarrow$ & Heath bell & $\begin{array}{c}\text { Campanula ro- } \\
\text { tundifolia }\end{array}$ \\
\hline
\end{tabular}


Highland clans. Gaulis. Scottish. English. Classical.

M`Donnell

Mountain Erica vulgaris heath

M'Dougall

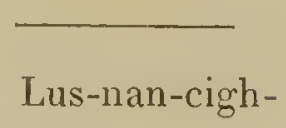

Cypress

Cypressus

M'Farlane reag

Cloud BerryRubus chamoheath morus

$M^{\prime}$ Gregor

An Giuthas

Scotch fir Pynus sylves-

tris

M`Intosh

M·Kay

Boxwood Buxus

Bulrush Scirpus lacus-

$$
\text { tris }
$$

M'Kenzie Cip-chaan-du’ Anstra- Deer grass Scirpus caspi-

libus

tosus

M‘Kinnon

Achlasan-

St. John's Hypericum per-

Challum chille wort

foratum

M`Lachlan

Craobh-chao- Roan

Mountain Sorbusaucuparain ash ric

M'Lean
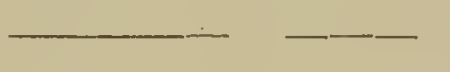

Black berry heath

M`Leod

Lus-nambraoileag

$\mathrm{M}{ }^{`} \mathrm{Nab}$

M`Neill

Feamainn

SeaWare Bladder fu- Fucus vesiculos cus

M'Pherson

Variegated Buxus box

$M^{`}$ Q uarrie

Black thorn Prunus spinosa 
Highland clans. Gunlis. Scottish. English. Classical.

M·Rae

Munroe

Menzies

Murray

Ogilvie

Oliphant

Roberts
Rose
Ross
Sinclair

Stewart

Sutherland
Garbhag-an-tfleibh

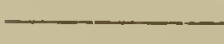

Ninsionn

An-t'arteal

An sgitheach

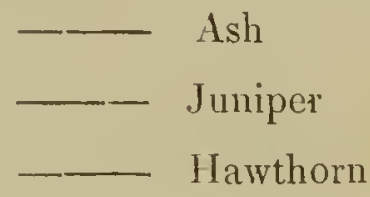

Fraxinus

Juniperus

Cratcegus oxyacantha

Lycopodium selago

Eagles feathers cer pseudotree platanus Brachens Fern Pteris aquilina An fhearrBriar rose Rosa canina dhris

BraoileagaBear berries Arbutus uva ursi nan-con

Seamar

Clover

Trifolium repens

Cluas-anThistle

Curdus fheìdh
Cats-tail grass
Phleum nodosum

In addition to these emblems the chief of each respective clan wore two eagles' feathers attached to the badge in his bonnet.*

* Blackwood's Magazine. 
Poetical fiction makes the use of heraldic ensigns of greater antiquity than the globe itself.

"He from the glittering staff unfurl'd

Th' imperial ensign, streaming to the wind,

With gems and golden lustre rich emblaz'd, Seraphick arms and trophies."

Paradise Lost.

That the use of heraldic emblems greatly increased throughout Europe during the crusades is generally known, and where, as a flattering badge, every private soldier wore a cross of red stuff sewed to his surcoat, from which circumstance these romantic wars were called crusades, from croisades. Achievements were also painted on the outer tunic or coat, and from this custom originated the term " coat of arms." But the rudeness of the delineation of the artists of those days frequently caused the representation to be misconceived, even the fleur-de-lys has often been taken for trefoil, and sometimes drawn as a spear's head. The 
lions painted on the banner of Richard the First were taken for leopards.

"Tu vedi ben quella bandiera grande

Ch' insieme pou le fiordiligi e i pardi."

Orland. Fur. Cant. x. st. 76.

"Yon ensign view, where waving in the wind

Appear the fleur-de-lys and leopards join'd."

This verse alluded to the shield of Richard the First, which was suspended in the hall of the Knights Templars at Paris. Again it is thus mentioned in the romance of Richard "Cour" de Lyon."

"Upon his shoulders a scheld of stele

With the lybbardes painted wele."

Heraldic emblems were used in this country as long back as the year 1189, they were generally painted on a small shield and worn fastened to the belt. During feasts, and other pacific solemnities, the shield of each knight was suspended behind him.

"The scheldys hanginge on the hookes."

Lydgate. 
The stars and orders which modern sovereigns bestow on their princes and nobility, are merely emblematical ornaments of their monarchs favour.

His holiness the pope carries a representation of St. Peter's key as an emblem of great trust. And most of the European cities and towns derive their arms from some symbolical allusion to the history of their particular spot or neighbourhood, as the various incorporated companies have some device in their arms emblematical of their profession or trade. Thus King Edward the 'Third granted the Company of Grocers, a cheveron, gules, between nine cloves, sable. Henry the Seventh gave the Company of Merchant Taylors, a tent-royal between two parliamentary robes.

The Company of Apothecaries are represented by glorious Apollo mounted on the serpent Python, with a bow in one hand, and 
an arrow in the other; emblematical as we may suppose of their powers to assist death.

Emblems in general are ingenious pictures, representing one thing to the eye and another to the understanding. The rebus, or representations of names by familiar images was invented in Picardy, and imported to us by the English residing at Calais. This symbolical mode of describing proper names was in great use with the monks of those days, who sometimes made the analogy so remote as to require interpretation. When any name ended in " ton," the tun or vessel was usually substituted, of which numerous instances are found in stained glass. Thomas Compton, abbot of Cirencester in 1480, in a windorv of stained glass which he contributed to our lady's chapel at St. Peter's in Gloucester, has his rebus (a comb and a tun) very frequently repeated. John Naileheart, abbot of St. Augustines, near Bristol, in 1510, bore 
upon the escutcheon in his seal a human heart proper, pierced with five nails, in allusion both to the "quinque vulnera" and his own surname.

We have been too much amused by Peacham's account of the rebuses that were invented during the reign of Charles the First, to withhold them from our readers. This author says "Excellent have beene the conceipt of some citizens, who wanting armes, have coined themselves certaine devices as neere as may be alluding to their names, which we call rebus. Master Jugge the printer, (as you may see in many of his bookes,) tooke, to expresse his name, a nightingale sitting in a bush with a scrowle in her mouth, wherein was written Jugge, Jugge, Jugge."

"One Foxc-crafte caused to be painted in his hall and parlour a foxe, counterfeiting himselfe dead upon the ice, among a company of ducks and goslings." 
" One Master Gutteridge drew for himselfe a giant standing in a gutter, and looking over the ridge of a house, which could not chuse but make Gutteridge."

The same author says "A churchwarden of Saint Martins in the Fields, I remember when I was in that parish, to expresse Saint Martins in the Fields, caused to be engraven a martin (a bird like a swallow) sitting upon a molehill betweene two trees, which was Saint Martins in the Fields. It is there yet to be seene upon the communion cup."

The celebrated Le Notre, who planted the gardens of Versailles, Saint Cloud, the Tuilleries, the Champs Elysées, and several other royal pleasure grounds, was rewarded by a patent of nobility, by Louis the Fourteenth, on which occasion he chose for his arms a cabbage, with a spade and a rake for supporters; alleging that he owed so many obligations to gardening, that he would not 
have his descendants lose the remembrance of them.

In the gallant days of knight-errantry, respectful and faithful love often had rècourse to the symbolical language of flowers, and the bashful swains of our rural scenes still frequently explain their first passion by the assistance of these emblems. Although unpractised in the rules of the floral grammar, they are instructed by nature to seek the earliest or the fairest flower of the season, scarce knowing why they wait at the stile, or wherefore they enter the wicket to present it. Their wish is to please, the flower proves it, and a smile rewards them.

Cottage friendship is frequently commenced through the aid of flowers, for where the tongue is disposed, but reluctant to say to its neighbour, come let us live in friendship and kindness, a nosegay will explain the wish, and the offer of a few flowering plants 
expresses more powerfully a desire for good neighbourhood, than all the words of village dialect.

But to express ourselves more readily by floral emblems, it is necessary that we should lay down grammatical rules for the government of this silent language before we proceed to the dictionary of emblems.

The first principle is to observe that the pronoun $I$, or me, is expressed by inclining the flower to the left, and the pronoun thou, or thee, by sloping it to the right, but when represented by drawings on paper, these positions should be reversed, as the flower should lean to the heart of the person whom it is to signify.

The articles $a$, an, and the, may be expressed by a tendril, the first by a single line, thus ere, the second by a double tendril $\sim e$, and the third by one with three branches $25 \Omega$. 
The second rule is, that if a flower presented upright expresses a particular sentiment, when reversed it has a contrary meaning. Thus, for example, a rose bud upright with its thorns and its leaves means, "I fear, but I hope ;" if the same bud is returned held downwards, it signifies, "you must neither hope nor fear ;" but if the thorns be stripped off, it expresses, "there is every thing to hope;" deprived of its leaves, it signifies, "there is every thing to fear." Thus the expression may be varied of almost all the flowers by changing their position. The flower of the marigold, for example, placed on the head, signifies " trouble of spirits ;" on the heart, " trouble of love ;" on the bosom, "weariness."

'The pansy held upright denotes " hearts' ease "' reversed it speaks the contrary; when presented upright it is understood to say, " think of me;" but when offered pendant, it means " forget me." And thus the amaryllis, which is the emblem of pride, may be made to express " niy pride is humbled," or 
"your pride is checked," by holding it downwards either to the left or the right, as the sense requires.

In the same manner the wallflower, which is made the emblem of fidelity in misfortune, if presented with the stalk upwards, would insinuate that the person was considered no friend to the unfortunate. Thus various sentiments may be expressed by all the flowers noticed in these emblems, but which are principally intended as floral mottos. 

Flonal fimblems
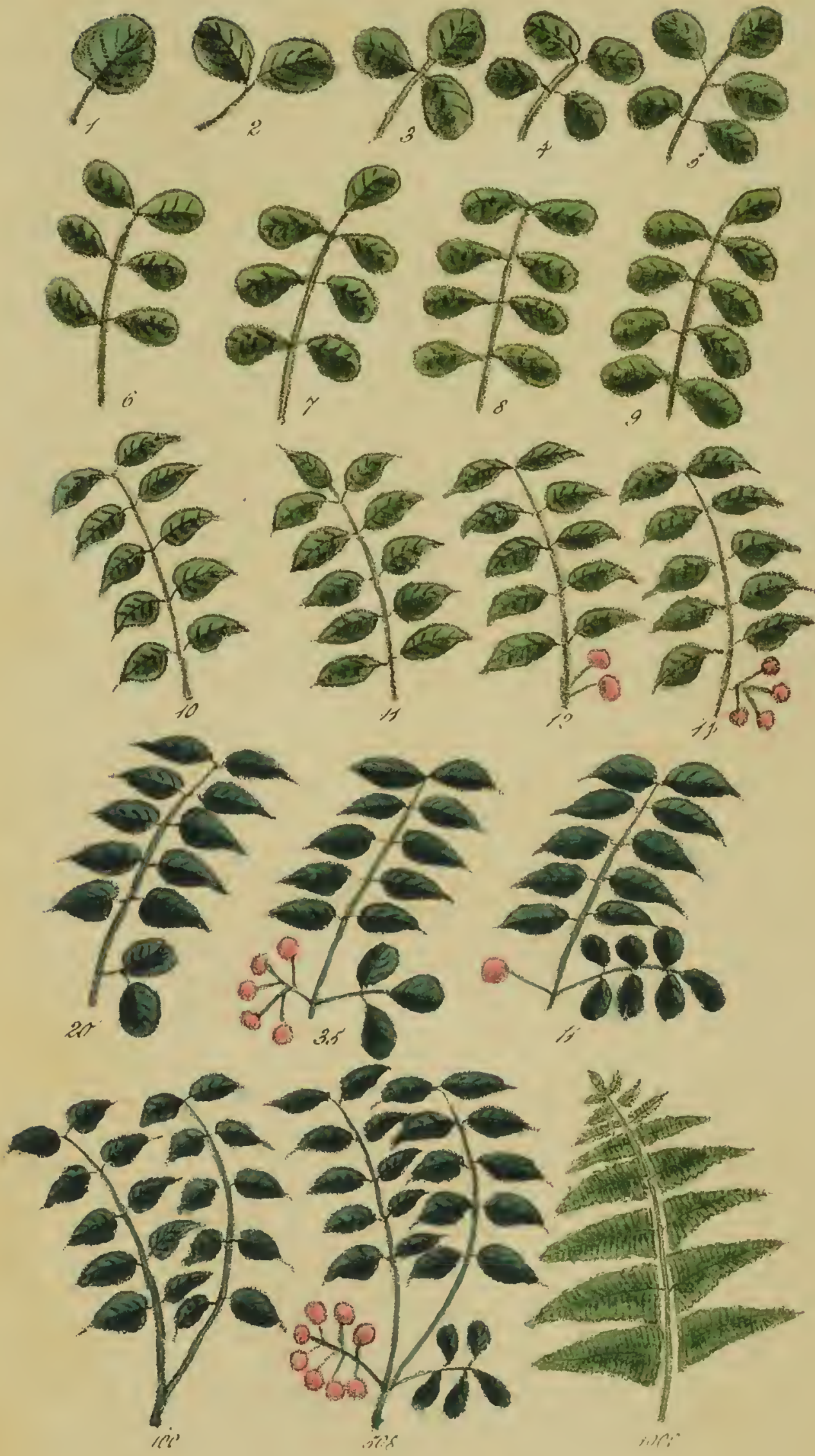


\section{LEAFLET NUMBERS.}

The numerical emblems are simply distinguished by leaflets as far as eleven. From eleven to twenty they are denoted by berries added to the tenth leaf. Twenty to a hundred is represented by joining a compound leaf to the tenth, which expresses two tens, and any odd number is formed by the addition of berries; thus three tens and five berries denote the number 35 .

A hundred is represented on the same principle by ten tens, and which may be increased by a third leaflet and a branch of berries as far as 999. A thousand is distinguished by a frond of fern or brake, to which a leaflet may be added to increase the number of thousands, in the same manner as 
the hundreds. Thus any given number may be explained, and plate may be embossed or engraved, and china painted or enamelled, so as to commemorate any event by ornamental emblems.

In representing sums of money, the pounds are to be expressed by round leaflets, the shillings by oval, and the pence by long pointed leaves. 

Floral fimbleas

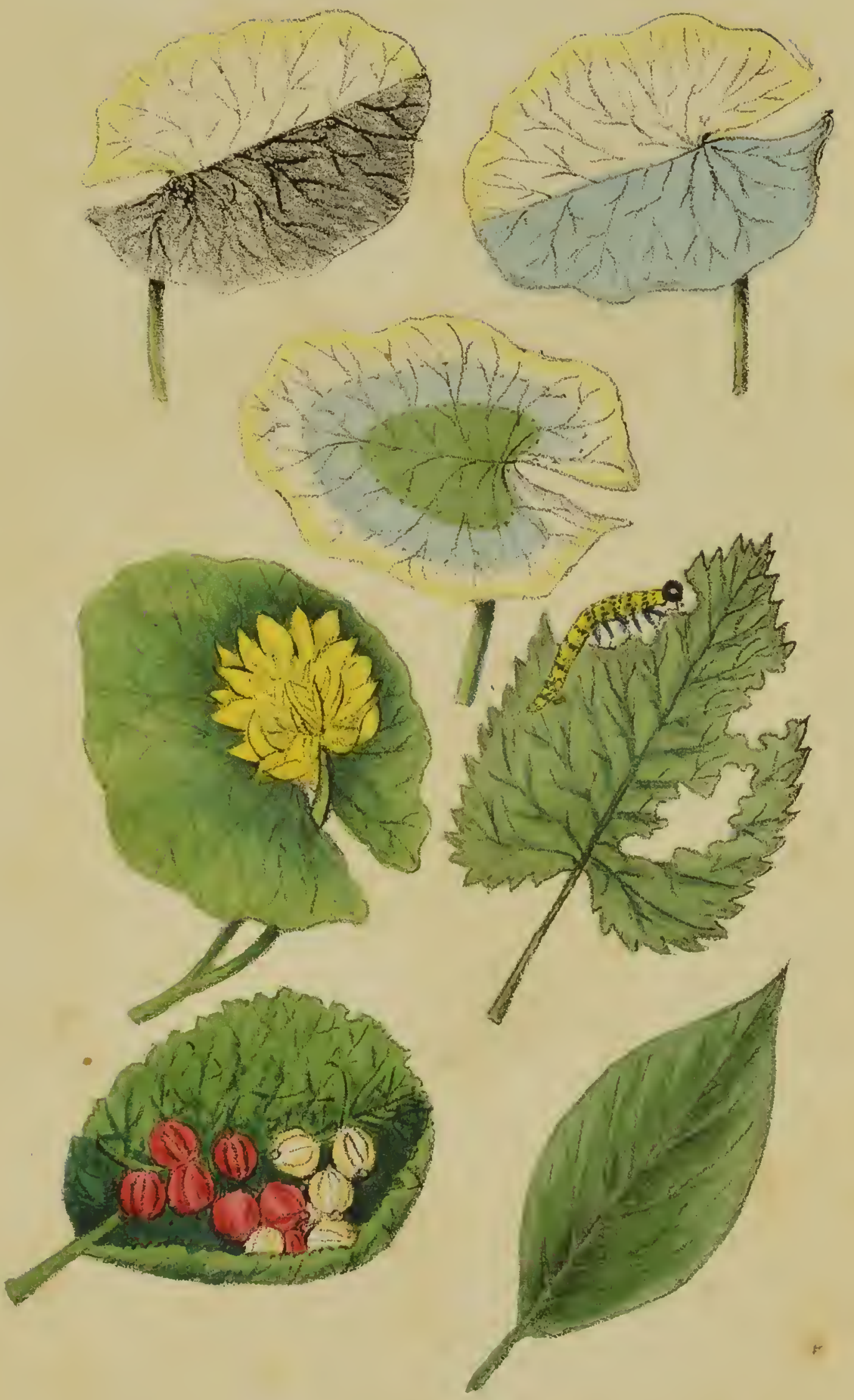




\section{EMBLEMATICAL LEAVES FOR EACH DAY OF THE WEEK.}

The emblems of days are portrayed on a single leaf, that they may be more readily distinguished from the numerical leaflets, and the monthly symbolical garlands.

The idea of representing the days, is from the creation, as described by Moses, who instructs us

"In the begimning how the heaven and earth Rose out of Chaos."

Milton.

\section{MONDAY.}

The emblematical leaf of this day, is that of the lotus or water lily, Nymphaca, equally divided by light and darkness. The lotus leaf 
has been selected because the eastern nations consider it the

"Emblem and cradle of creative night."

It was anciently revered in Egypt, as it is at present in Hindostan, Tibet, and Nepal, where they believe that it was in the consecrated bosom of this plant, that Brahma was born; and on which Osiris delighted to float.

This day derives its name from moon and day, it being anciently set aside for the worship of the changing luminary of the night.

" Queen of the silver bow !-by thy pale beam Alone and pensive, I delight to stray,

And watch thy shadow trembling in the stream,

Or mark the floating clouds that cross thy way. And while I gaze, thy mild and placid light

Sheds a soft calm upon my troubled breast:

And oft I think-fair planet of the night,

That in thy orb the wretched may have rest:

The sufferers of the earth perhaps may go,

Releas'd by death-to thy benignant sphere ;

And the sad children of despair and woe

Forget, in thee, the cup of sorrow here."

Charlotte Smith. 


\section{TUESDAY.}

The symbolical leaf of Tuesday is divided into the waters and the heavens, which are distinguished by one half being light, and the other blue or sea green.

This day is called Tuesday after the Saxon name which signifies the day of Mars, "the dreadful god of war," and from hence the French call it Mardi.

\section{WEDNESDAY.}

The emblematical leaf for this day is divided into three colours, light for the heavens, blue for the waters, and green for the earth.

"Th' imprison'd sea, that restless ebbs and flows, The fluctuating fields of liquid air, And the wide regions of the land, proclaim The power divine, that rais'd the mighty frame."

Blackimore. 
Wednesday takes its derivation from the Goths, who named it after their god Woden, or Odin. Scandinavian Mythology informs us, that Odin put off his mortality in Sweden, declaring, that he was going into Scythia to join the deities at the immortal banquet, where he would receive those who died with arms in their hands. The Swedes call this day Odensday, it being most probably the day on which that great warrior died.

" I was rock'd in giants' cradle,

Giants' lore my wisdom gave;

I have known both good and evil,

Now I lie in lowly grave."

Herbert's Helga.

\section{THURSDAY.}

This day is represented by a green lotus leaf, in which is placed the flower as figurative of the luminary then created.

"Nature's high birth her heavenly beauties show;

By every feature we the parent know. 
'Th' expanded spheres amazing to the sight, Magnificent with stars and globes of light."

Blackstone.

Thursday may be drawn or represented by any leaf on which are placed daisies or other star flowers.

This day was dedicated to Thor, the son of Odin; we appear to have corrupted the name from the Danish, Thorsgday.

\section{FRIDAY.}

"Let the earth bring forth the living creature."

The emblem of this day is an insect feeding on a leaf.

The etymology of Friday, Frea's-day, is derived from Freya, Frea, or Frigga, a Saxon deity, who was wife to Odin. She was wor- 
shipped by most of the German tribes, and her principal temple was at Upsal.

\section{SATURDAY}

"I have given you every herb bearing seed, and every tree, in which is the fruit."

The hieroglyphic leaf for Saturday is therefore filled with fruit.

"The toil-worn cotter frae his labour goes,

This night his weekly moil is at an end;

Collects his spades, his mattocks, and his hoes,

Hoping the morn in ease and rest to spend."

Burns.

Etymologists disagree respecting the derivation of the word Saturday. Some suppose it to have been so called after the Grecian deity Saturn, but as the other days of the week owe their names to the Scandinavians, it is most reasonable to surmise that this day was named after the Saxon idol ræe p. 


\section{SUNDAY.}

The Sabbath day is distinguished by a simple olive leaf.

This day was anciently dedicated to the bright luminary of day, and from hence was called Sun-day, after the Gothic sunno, or the Saxon word sunna.

Sabbath is derived from an Hebrew word, signifying rest.

"Here ev'ry day was Sabbath : only free From hours of pray'r for hours of charity;

Such as the Jews, from servile toil releast,

Where works of mercy were a part of rest ;

Such as blest angels exercise above,

Vary'd with sacred hymns and acts of love!"

Dryden.

Graham pictures the blessings of the Christian Sabbath in the following beautiful lines:

"Hail, Sabbath! thee I hail!-the poor man's day, On other days the man of toil is doom'd 
To eat his joyless bread lonely-the ground, Both seat and board, screen'd from the winter's cold And summer's heat by neighbouring hedge or tree; But, on this day, embosom'd in his home, He shares the frugal meals with those he loves.With those he loves, he shares the heartfelt joy Of giving thanks to God-not thanks of form, A word and a grimace; but reverently, With cover'd face and upward earnest eye!

Hail, Sabbath, thee I hail ! - the poor man's day; The pale mechanic now has leave to breathe The morning air, pure from the city's smoke. While wandering slowly up the river side, He meditates on Him whose power he marks In each green tree, that proudly spreads the bough As in the tiny dew-bent flowers that bloom Around its roots-and while he thus surveys With elevated joy each rural charm, He hopes, yet fears presumption in his hope, That Heav'n may be one Sabbath without end!" 

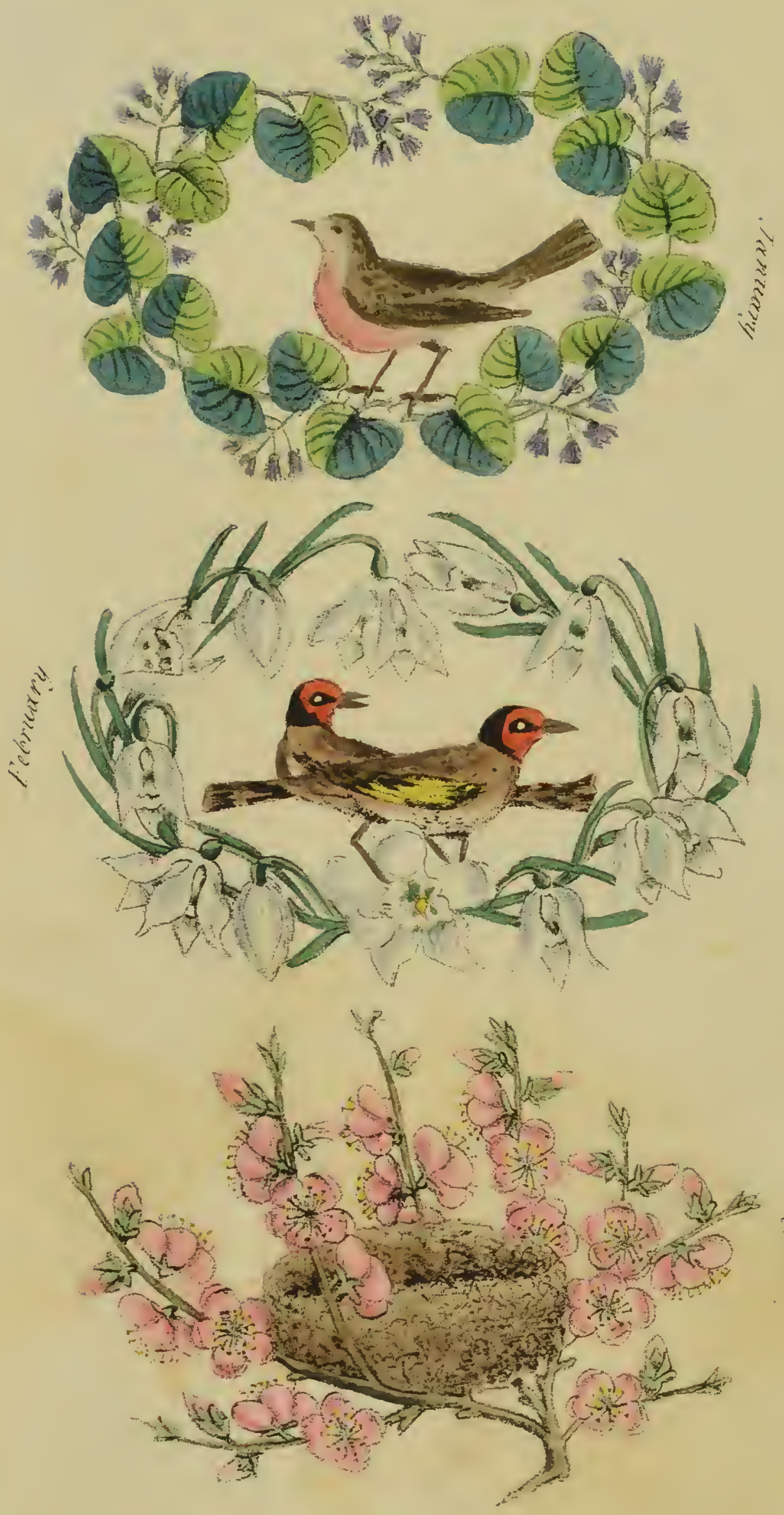

ํ. 


\section{EMBLEMS FOR THE CALENDAR MONTHS.}

\section{JANUARY.}

"Come, melancholy moralizer-come!

Gather with me the dark and wintry wreath;

With me engarlan'd now."

Le jour de l'an."

'This month is represented by a robin encircled in a garland of sweet-scented tussilage, Tussilago fragrans. Since the one cheers our dwellings at this season by its cherup, whilst the other regales the early month by its fragrance.

"Hail! then-hail to thee, January, all hail!

Cold and wintry as thou art."

"—_ Hark! even now the merry bells ring round With clamorous joy to welcome in the day,

This consecrated day,

To Mirth and Indolence." 
"The Red-breast

Half afraid, he first

Against the window beats : then, brisk, alights

On the warm hearth; then, hopping on the floor, Еуеs all the smiling family askance, And pecks, and starts, and wonders where he is; 'Till more familiar grown, the table crumbs Attract his slender feet."

Peacham says, "January should be clad all in white, like the colour of the earth at this season, blowing his nails; in his left arm a billet, the sign Aquarius standing by his side."

This month and the next were added to the year by Numa Pompilius, and had the name from Janus, a Roman god, painted with two faces, (signifying providence or wisdom, ) judging by things past of things to come. 


\section{FEBRUARY.}

"You have such a February face, So full of frost, of storm, and cloudiness."

Shakspeare.

As an emblem for this month, is presented a wreath of Snow-drops, Galanthus nivalis, surrounding a pair of Goldfinches, as birds usually couple about the middle of February, when the good Bishop St. Valentine's day is celebrated ; for,

"All the air is his diocese, And all the chirping choristers And other birds, are his parishioners.

He marries every year

The lyrique lark, and the grave whispering dove;

The sparrow, that neglects his life to love;

The household bird with red stomacher;

He makes the blackbird speed as soon

As doth the goldfinch or the halicon."

"February" says Peacham, "shall be clothed in a dark sky colour, carrying in 
his right hand, with a fair grace, the sign Pisces.

Numa Pompilius gave February its name a Febrlbus, from Agues, to which this season is much subject; or from Februa, which were sacrifices offered for the purgation of the souls of the dead; for Februs was an old verb, and signified to purge.

\section{MARCH.}

"Be patient, swains; these cruel seeming winds Blow not in vain."

\section{Thompson.}

An old distich says,

"March winds and April showers, Bring forth May flowers."

The hieroglyphics by which we would distinguish this month are a bird's nest encircled in a garland of amygdalus, the almond,

"That blooms on a leafless bough." 


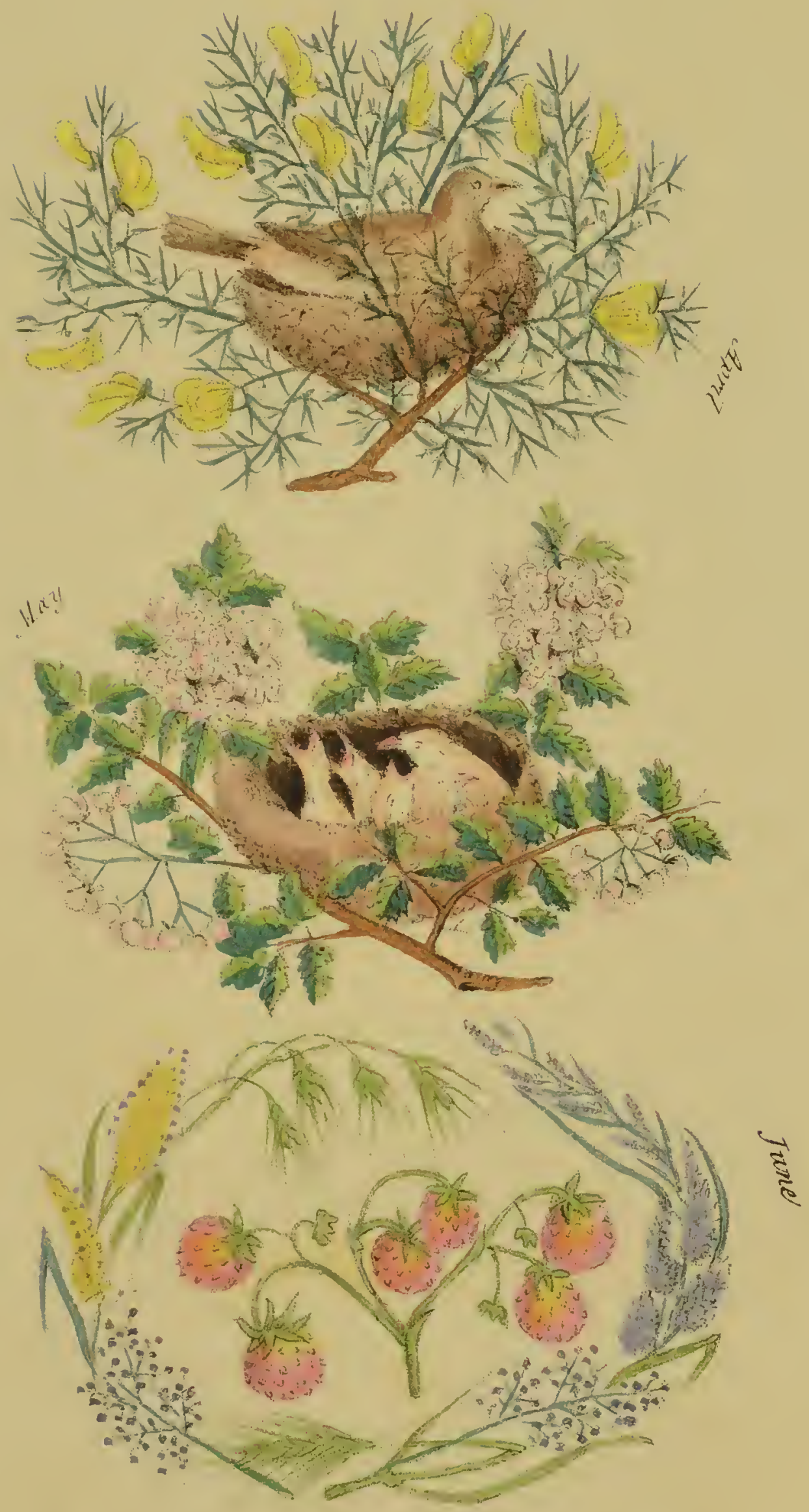

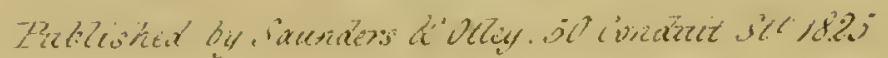


Peacham pictures March in a "tawny dress, with a fierce aspect, a helmet upon his head, to show this month was dedicated to Mars his father; the sign Aries in his right hand, leaning upon a spade, in his left hand almond blossoms and sciens; upon his arm a basket of garden seeds."

\section{APRIL.}

"Men are April when they woo; December when they wed."

Shakspeare.

As emblematical of the month when "The clouds consign their treasures to the fields ;" we have pictured a linnet in her nest, surrounded by a branch of

"The vernal furze

With golden baskets hung! Approach it not, For ev'ry blossom has a troop of swords

Drawn to defend it."

Hhordis. 
Peacham draws "April as a young man in green, with a garland of myrtle and hawthorn buds; in one hand primroses and violets, in the other the sign of Taurus. This month hath the name $a b$ aperiendo," says Varro, "because now the earth begins to lay forth her treasures to the world."

" Fair handed spring unbosoms every grace."

\section{MAY.}

"Love, whose month is ever May."

“ Maids are May, when they are maids, But the sky changes when they are wives." As You Like It.

"Hail! bounteous May, that dostinspire Mirth and youth, and warm desire; Woods and groves are of thy dressing, Hill and dale doth boast thy blessing."

Milton. 
A branch of hawthorn in full flower, supporting a nest of young birds " demanding food with constant clamour," is presented as the emblem of May.

"May," says Peacham, " must be drawn with a sweet and amiable countenance, clad in a robe of white and green, embroidered with daffodilles, hawthorn, and blewbottles; upon his head a garland of white, damask, and red roses; in one hand a lute, upon the forefinger of the other a nightingale, with the sign gemini : it was called Maius à majoribus ; for Romulus having divided the people of Rome into two parts, majores and minores, whereof the younger were appointed to defend their country by strength, the elder by counsel.

May, so called in the honour of one, and June of the other,"

"Hinc sua majores tribuêre vocabula Mĩa, .Junis à invemum nomine diclus adest."

Ovid. 


\section{JUNE.}

"Child of the sun, refulgent summer comes, In pride of youth."

Thompson.

\section{"Now the air}

Is rich in fragrance! fragrance exquisite As new mown hay!"

Mis. Robinson.

A wreath of various grasses in flower, encompassing a branch of strawberries, is presented as our emblem of the month of June. Peacham dressed June in a mantle of dark grass green; upon his head a garland of bents, king-cups, and maiden's hair ; in his left hand an angle with a box of cantharides, in his right the sign of cancer, upon his arm a basket of the fruits of the season; it hath the name either à Junvenibus, as observed in May, or of Junius Brutus. 

Floral Emblems.

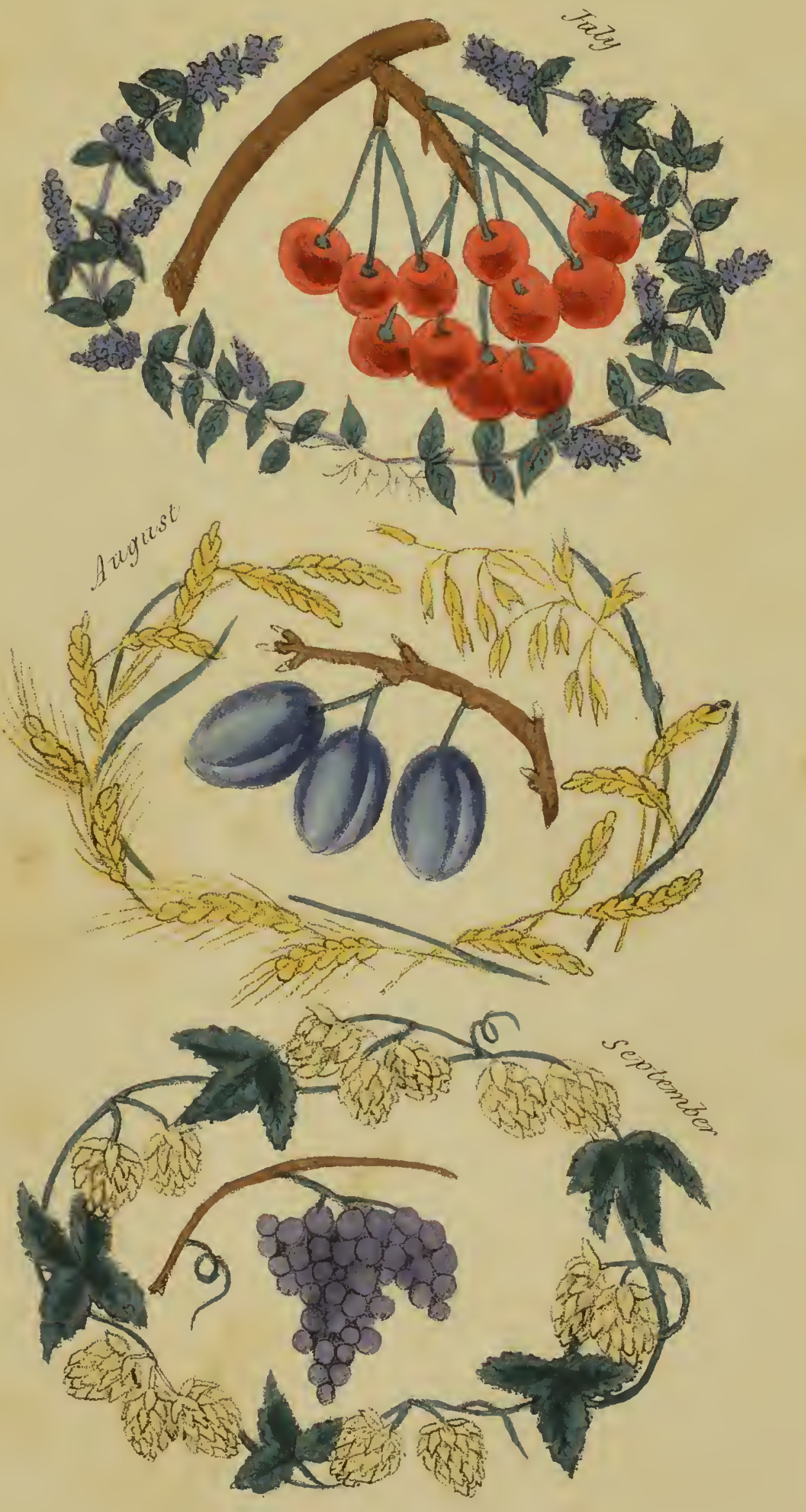




\section{JULY.}

"When now no more th' alternate iwins are fir'd, And cancer reddens with the solar blaze; Short is the doubtful empire of the night."

Thompson.

This cherry-cheeked month we picture in our emblems by a garland of purple thyme, enclosing a bunch of red cherries.

"July I would have drawn," says Peacham, " in a jacket of light yellow, eating cherries, with his face and bosom sun-burnt, on his head a wreath of centaurie and wild thyme, a sithe on his shoulder, and a bottle at his girdle carrying the sign Leo. This month was called July in honour of Julius Cresar, the dictator, being before called Quintilis, or the fifth month ; for the Romans began with March." 


\section{AUGUST.}

"Before the ripen'd field the reapers stand, In fair array."

Thompson.

This month, which was anciently called Sextilis, from being the sixth from March, was named August by the senate of Rome, in honour of Augustus Cæsar, who in this month was created consul, and triumphed thrice in Rome. It was in this month also that he subjugated Egypt to the Roman empire, and terminated the civil wars which had so much convulsed these warlike people.

As a symbol of this month we weave a wreath of wheat, barley, and oats, encircling a branch of purple plums.

August is portrayed by Peacham in "form 
of a young man of a fierce and choleric aspect, in a flame coloured garment; upon his head a garland of wheat and rye, upon his arm a basket of ripe fruits, as pears, plums, apples, gooseberries : at his belt, a sickle bearing the sign Virgo."

\section{SEPTEMBER.}

— By the potent sun elated high,

The vineyard swells refulgent on the day."

Thompson.

The etymology of the name of this morth is derived from its being the seventh from March.

September may be considered the festival month of jolly Bacchus.

"For clust'ring grapes are his peculiar care."

We have therefore given as our emblem of 
this month, a cluster of purple grapes, surrounded by a wreath of hops.

The author of the Complete Gentleman describes "September with a merry and cheerful countenance, in a purple robe, and a wreath of white and purple grapes upon his head: in his left hand a handful of millet oats, and panicle, carrying a cornucopia of ripe peaches, pears, pomegranates, and other fruits of his season, in his right hand the sign Libra." "His purple robe sheweth how he reigneth like a king above other months, abounding with plenty of things necessary for man's life."

\section{OCTOBER.}

"Ye swains, now hasten to the hazel bank."

$$
\text { * * * * } \quad * \quad * \quad * \quad *
$$

Fit for the thickets and the tangling shrub, Ye virgins come. * * * * * * 
Floral Fmblems

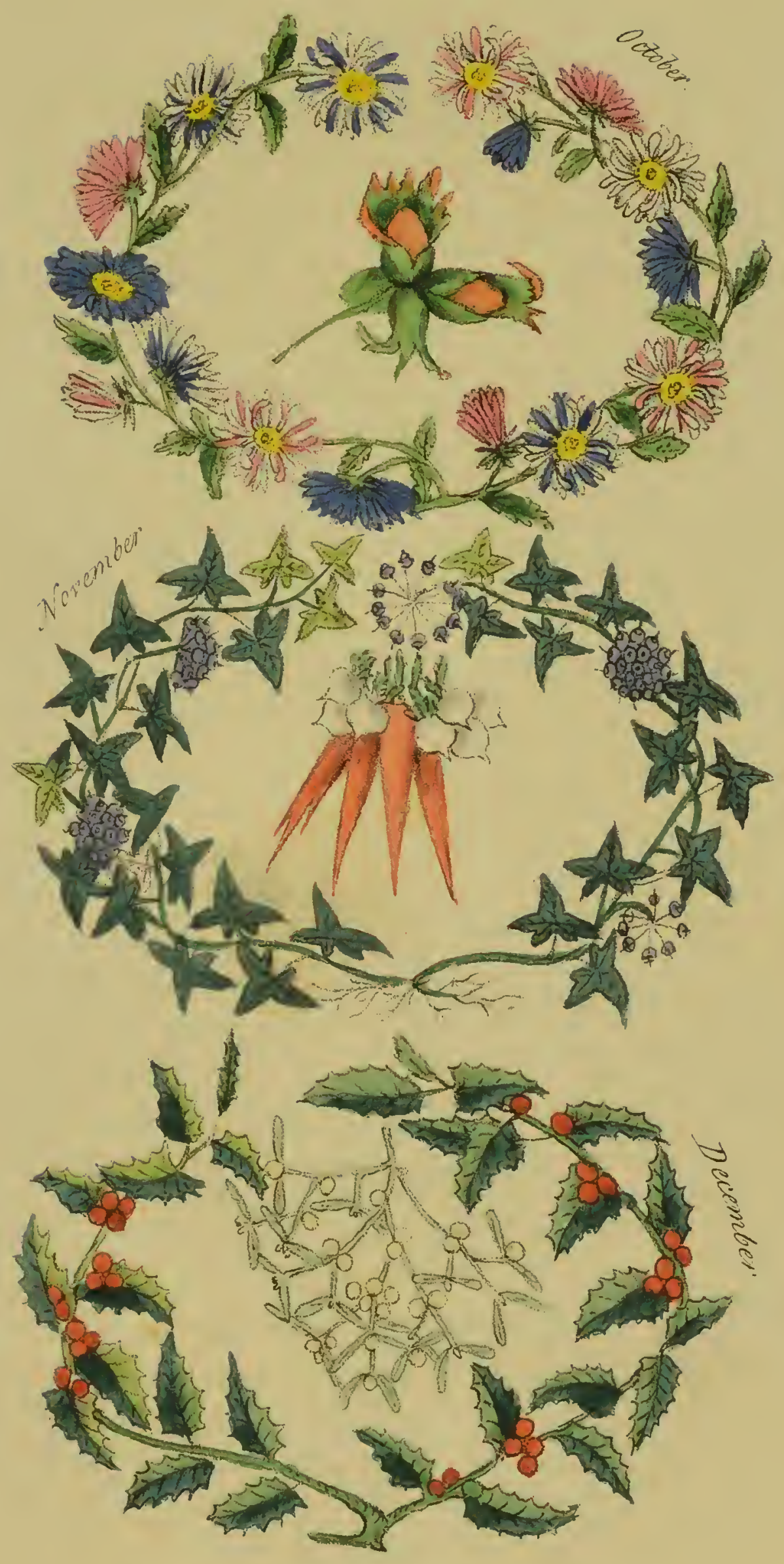



* * * * the clustering nuts for you

The lover finds amid the secret shade;

And where they burnish on the topmost bough, With active vigour crushes down the tree;

Or shakes them ripe, from the resigning husk, A glossy shower."

Hieroglyphically we emblazon this month by a wreath of purple, crimson and white china asters, surrounding clusters of ripe hazel nuts.

In the reign of Charles the First, October was represented, "In a garment of yellow and carnation, upon his head a garland of oak leaves and acorns, in his right hand the sign Scorpio, in his left a basket of servises, medlars, and chestnuts, and other fruits that ripen late in the year; his robe the colour of the leaves and flowers decaying."-Peacham.

Domitian, the last of the twelve Cæsars, commanded that this month should be called after himself, Domitianus; but he was no 
sooner assassinated than the senate, in order to obliterate the name of so detestable a tyrant, decreed that it should be called October.

\title{
NOVEMBER.
}

" November chill blaws loud wi' angry sugh ;"

\begin{abstract}
" the sun
Scarce spreads thro' æther the dejected day.

Faint are his gleams, and ineffectual shoot

His straggling rays, in horizontal lines,

Thro' the thick air ; as cloth'd in cloudy storm,

Weak, wan, and broad, he skirts the southern sky;

And, soon-descending, to the long dark night,

Wide-shading all, the prostrate world resigns."
\end{abstract}

Thompson.

"An ivy-wreath, fair learning's prize, Raises Mæcenas to the skies."

Horace.

We would enliven this month of damp clouds and dull spirits by a garland of ivy in 
flower, since of old it was employed to adorn both the brow and the bowl of Bacchus. And we know not a prescription better calculated to disperse the ennui of November than an interesting author and a flowing bowl. From the centre of the garland we suspend a bunch of turnips and carrots.

Peacharn draws "November in a garment of changeable green and black, with a garland of olives on his head, a bunch of parsnips and turnips in his left hand, and the sign Sagitarius in his right.

\section{DECEMBER.}

"Tho' now no more the musing ear

Delights to listen to the breeze, That lingers o'er the green wood shade

I love thee, Winter, well."

\section{Southey}

$\mathrm{F}: 2$ 
As emblematical of hospitality's festive month.

"The cluster'd berries claim the eye O'er the bright holly's gay green leaves :"

We therefore weave our garland with this glossy foliage intermixed with its vermilion berries, from the centre of which we suspend a branch of mirth-inspiring misletoe.

Peacham says "December must be expressed with a horrid and fearful aspect, clad in Irish rugge, or coarse freeze girt upon him, instead of a garland upon his head, three or four night-caps, with a Turkish turban over them. His nose red, his mouth and beard clogged with icicles, at his back a bundle of holly, ivy, or misletoe, holding in furred mittens the sign of Capricornus.

We shall conclude our emblems of the months by Peacham's instructions to the painters of the seventeenth century. 
“Moreover you must be sure to give every moneth his proper and naturall landtskip, not making (as a painter of my acquaintance did in severall tables of the moneths for a nobleman of this land) blossomes upon the trees in December, and schoole-boyes, playing at nine pinnes upon the yce in July."

We derive the names of the months from classical languages, and those of the days from the Gothic tongue. 



\section{FLORAL EMBLEMS.}

\section{DIC'ITONARY OF EMBLEMS.}

\section{ABSENCE.}

Wormwood.-Artemisia Absinthium.

"She was wean'd; I had then laid Wormwood to my breast."

Romeo and Juliet.

WE read in Watts's Logic, that "Bitter is an equivocal word; there is bitter wormwood, there are bitter words, there are bitter enemies, and a bitter cold morning." And we 
will ask, who has not felt the bitterness of absence ?

"In spring the fields, in autumn hills I love;

At morn the plains, at noon the shady grove;

But Delia always : absent from her sight,

Nor plains at morn, nor groves at noon delight."

Pope's Past.

\section{ACCOMMIODATING DISPOSITION.}

Valerian.-Valeriana Rubra.

"Gay loosetrife there and pale Valerian spring."

Scott.

This plant propagates itself with equal facility in the rich borders of the parterre, or in the dry crevices of old walls, hence the emblem. It was formerly called Setewale. Chaucer says,

"Ther springen herbes grete and smale, The Licoris and the Setewale." 


\section{ACTIVITY.}

\section{Thyмe.-Thymus.}

" O'er fringed heaths, wide lawns, and mountain steeps, With silent step the artful Thyma creeps, Unfolds with fragrant bloom her purple flow'rs, And leads with frolic hand the circling hours."

Rowden.

The active qualities of this plant are duly appreciated by epicures, since it excites and rouses their appetites, by rendering every dish savoury in which it is used. We are told, that the highest flavoured venison is always found where this penetrating herb abounds. Bees seek it with great activity: the honey of Athens was esteemed the best in the world, on account of the thyme which grew on the hills which surrounded that city.

"With shepherds on the thyming downs, I love to pass the summer's day."

Williams. 


\section{ACUTE SORROW, OR AFFLICTION.}

$$
\text { Aloz.-Aloe. }
$$

"The woful teris that thei letin fal As bittir werin, out of teris kinde, For paine, as is ligne aloes, or gal."

Chancer.

The aloe is made the emblem of acute sorrow, on account of its painful bitterness. The bitter of the aloe affects the body, that of affliction reaches the soul.

"Sorrow that locks up the struggling heart."

Akenside.

"If you do sorrow at my grief in love, By giving love your sorrow and my grief Were both extermin'd."

Shakspeare.

"Besides, you know,

Prosperity's the very bond of love;

Whose fresh complexion, and whose heart together, Affliction alters."

Winter's Tale. 


\section{ADROITNESS.}

Spider Ophrys.-Ophrys aranifera.

"The spider's touch, how exquisitely fine!

Feels at each thread, and lives along the line."

Pope.

This flower is made emblematical of adroitness or skilfulness, in allusion to the insect it resembles.

\section{AFTERTHOUGHT.}

Catesby's StaR-wort.-Aster grandiflorus.

This North American plant has been made to represent afterthought, because it sends forth its flowers in the month of November, when most others have disappeared. 
Afterthoughts are good when properly used, but bad when " Afterthought, and idle care, And doubts of motley hue, and dark despair; Suspicions, and fantastical surmise; And jealousy, suffus'd with jaundice in her eyes, Discolouring all she view'd

Dryden's Fables.

\section{AGITATION.}

Moving Plant.-Hedysarum gyrans.

“Where dwells this sov'reign arbitrary soul, Which does the human animal controul, Inform each part, and agitate the whole?"

Blackmore.

There is not a greater phenomenon in the history of plants than is exhibited in this native of the banks of the Ganges.

It is difficult to account for the voluntary motion of the leaves of this plant, which does 
not seem to depend upon any external cause, and is not occasioned by any touch, irritation, or movement in the air; or is affected by the sun's rays, for the plant is fond of shade, and the leaves revolve well on rainy days, and during the night; - but when exposed to too much wind or sun, it is quiet. One leaflet is frequently revolved, whilst the others on the same petiole are quiescent; sometimes about half the leaflets are in motion at the same time, and at others the whole plant is agitated as if it had a soul ill at rest. 


\section{AMIABLENESS。}

White Jasmine.-Jasminum Officinale.

"The jessamine, with which the queen of flowers To charm her god, adorns his favourite bowers; Which brides by the plain hand of neatness drest, Unenvied rival! wear upon their breast; Sweet as the incense of the morn, and chaste As the pure zone which circles Dian's waist."

Churchill.

The beauty of this unassuming flower is even surpassed by its delightful odour; may we thus always find loveliness accompanied by amiability,

"And brides, as delicate and fair As the white jasmine flowers they wear."

T. Moore. 


\section{ARCHITECTURE.}

$$
\text { Candy-TuFt.-Iberis. }
$$

" Our father's next, in architecture skill'd Cities for use, and forts for safety build :

Then palaces and lofty domes arose ; These for devotion, and for pleasure those."

Blackmore.

This little plant has been made the emblem of architecture, because its flowers are disposed in stories from the bottom of the stalk to the top, producing a resemblance to the open columns of one of the most delicate orders of architecture. 


\section{ARDOUR.}

CuCKOW-PINT.-Arum maculatum.

“Voyez, ô prodige étonnant!

L'Arum, qu' admire l'Italie,

Si le næud de l'hymen la lie,

Lancer, de son spadix brulant,

Un feu bien plus etincelant

$\mathrm{Qu}$ 'à toute autre heure de sa vie."

The phenomenon which this plant displays at the period of impregnation, determined the poets to make it the emblem of ardour.

\section{ARGUMENT.}

FIG.-Ficus.

"Beneath his ample leaf, the luscious fig."

Thompson.

This emblem is derived from the circumstance of Cato's taking a fig in his hand, when he stimulated the Roman senators to declare 
war against Carthage. "It is not yet three days," said this orator, "since this fig was gathered at Carthage; and by it see how near to the walls of our city we have a mortal enemy." With this argument he prevailed upon them to begin the third Punic war, in which Carthage, that had so long been a rival to Rome, was utterly destroyed.

Argument is frequently used as a battering: ram by those who wish to force their opinions on others.

\section{ART. \\ BEAR'S-BREECH.-Acanthus.}

"Two bowls by the same skilful hand I've turn'd, The handles round, and with green leaves adorn'd, Of soft acanthus."

Lauderdale's Virgil.

The acanthus being also the plant from which Callimachus modelled the Corinthian 
chapiter, it has been very properly made emblematical of art.

"The art of our necessities is strange, That can make vile things precious."

Shakspeare.

\section{ARTIFICE.}

VrRGIN's-BOWER.-Clematis flammula.

"Clematis, wreath afresh thy garden bower."

"And virgin's bower, trailing airily."

Keats.

When artifice is innocently resorted to for the purpose of giving pleasure, it may be compared to the agreeable fragrance of the sweet clematis. But when it is used to entangle the unwary, it becomes the agent of him whom Milton thus describes;

"He, soon aware,

Each perturbation smooth'd with outward calm, Artificer of fraud! and was the first

That practis'd falsehood under saintly show." 


\section{ASSIDUITY.}

\section{Lavenner.-Lavendula Spica.}

"And lavender, whose spikes of azure bloom

Shall be erewhile in arid bundles bound,

To lurk amidst her labours of the loom,

And crown her kerchiefs clean with mickle rare perfume."

Shenstone.

In the floral emblems of the Turks this agreeable plant represents assiduity; but the continental emblematists make it symbolical of mistrust and disunion, because it is frequently used to cover disagreeable odours.

Mistrust can only belong justly to such as are accustomed to cheat and deceive, and those need no greater curse for their misdeeds. 


\section{ASSIGNATION.}

Pinpenner.-Anagallis.

"Clos'd is the pink-ey'd pimpernel.

消

* * *

'Twill surely rain, I see, with sorrow;

Our jaunt must be put off to-morrow."

Dr. Jenner.

This sensitive little flower is made the symbol of assignation, because the closing of its petals foretels wet; but when fully expanded it proclaims fair and dry weather. It is consequently called the peasant's barometer, and the shepherd's weather-glass.

The peasant loiters at the appointed stile, and the

\section{"Shepherd tells his tale}

Under the hawthorn in the dale."

Milton. 


\title{
ASYLUM, OR SUCCOUR.
}

\author{
JUNIPER.-I Iniperus.
}

"From lowest juniper to cedar tall."

"They shall be your refuge from the avenger of blood."

Joshua.

This shrub of the mountains, which sheltered Elijah from the persecutions of King. Ahab, has hence been selected as the type for an asylum.

Britannia may with just pride add this emblem to her national escutcheon, since in modern times, persons of all countries may say with the psalmist,

"Thou hast been a sheller for me, and a strong tower from the enemy." 


\section{ATTACHMENT.}

Scarlet-flowered Ipomga._-Ipomoa coceinea.

This beautiful plant is made the emblem of attachment from its entwining nature; which, like the bind weed of our fields, fixes itself to the first prop within its reach;

\section{" __ recompensing well}

The strength they borrow with the grace they lend."

Cowper.

\section{AUSTERITY.}

Fuller's Teasel.-Dipsacus fullonum.

"Let not austerity breed servile fear."

Rosrommon.

This plant is made the emblem of austerity from the extreme roughness of its conical receptacle, which is used to raise the nap upon woollen cloths, and hence its English name.

Austerity in courtship is generally followed by brutality in wedlock. 


\section{AVERSION.}

Cuina or Indan Pink.-Dianthus Chimensis.

"Hast thy uncertain bosom ever strove, With the first tumults of a real love?

Hast thou now dreaded, and now bless'd his swaty, By turns averse and joyful to obey?"

\section{Prior.}

We presume the China pink has been placed in floral hieroglyphics to represent aversion, in allusion to the custom of the Chinese, who wish to avoid all intercourse with other nations.

The great Verulam says,

"A natural and secret hatred and aversation towards society, in any man, hath somewhat of the savage beast." 


\section{BASHFUL MODESTY.}

Sensiture Plant.-Mimosa sensitiva.

"Whence does it happen that the plant, which well We name sensitive, should move and feel?

When know her leaves to answer her command, And with quick horror fly the neighbouring hand ?"

Prior's Solomon.

"This little plant-low cautiously it meets Th' approaching hand! advance, and it retreats! See how it flies from the suppos'd disgrace, And shrinks from contact of the rude embrace!

So wisdom folly should for ever shun; So virtue from the touch of vice should run; So female beauty should from flatt'ry fly, And spurn the incense of the gilded lie."

Modesty becomes the brave as well as the fair. Young says,

"Of boasting more than of a tomb afraid; A soldier should be modest as a maid." 


\title{
BASHFUL SHAME.
}

\author{
Paeny.---Peony. \\ "There might ye see the piony spread wide." \\ Cowper.
}

The blushing petals of this flower are made symbolical of the countenance that is rouged with conscious shame.

Impudence frequently takes delight in painting the cheeks of females, by talking in a way that modesty cannot answer. These should be treated as the nettles of society. 


\section{BEAUTY.}

$$
\text { FULl-BLOWN Rose.---Rosa. }
$$

"Emblem of beauty! for to thee it is That passion likens woman's loveliness."

Fitzjohn.

"Rose! thou art the sweetest flower" That ever drank the amber shower;

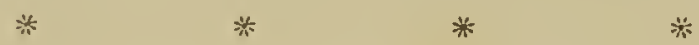

Even the gods, who walk the sky, Are amorous of thy scented sigh."

Moore's Anacreon.

This queen of flowers is considered the pride of Flora, and the emblem of beauty in every part of the globe.

Locke says, "Beauty consists of a certain composition of colour and figure, causing delight in the beholder." And trouble in the breast say the Damons of every age.

"Your beauty was the cause of that effect, Your beauty, that did haunt me in my sleep." 
The rose is also symbolical of England, but for which we would select the variegated or carnation rose, commonly called the York and Lancaster rose.

" Emblem of England, hail! thou fairest flower, That paints the garden and perfumes the gale."

Fitzjolun.

\section{BEAUTY ALWAYS NEW.}

China Rose.---Rosa Semperforens.

$$
\text { "Rose, }
$$

Unbent by winds, unchill'd by snows,

Far from the winters of the west,

By every breeze and season blest,

Returns the sweets by nature given

In softest incense back to heaven;

And grateful yields that smiling sky,

Her fairest hue, and fragrant sigh."

Lord Byron.

Moderate beauty when combined with innocent playfulness is constantly delighting by 
the fresh charms it displays. Like the China rose, which although it is neither the most fragrant or beautiful, is perhaps the most valuable, since its duration is prolonged by a succession of beauties.

\section{BEAUTY IS YOUR ONLY ATTRACTION.}

Japan Rose.-Camellia Japonica.

"Of colours, changing from the splendid rose, To the pale violets dejected hue."

Alienside.

This beautiful flower, the pride of the Japanese grove, although it attracts all eyes by its beauty, fails for want of fragrance to attach us like the rose, whose essence renders it more precious than even its unequalled beauty.

" Amoret, my lovely foe, Teil me where thy strength doth lie : Where the power that charms us so, In thy soul, or in thy eye?"

Waller. 


\section{BENEFICENCE.}

Potatoe.-Solanum tuberosum.

This root, which forms alike the poor man's bread and the rich man's luxury, is properly made the representative of beneficence. It is the palladium against famine, forming flour without a mill, and bread without an oven. It was first procured when

"Raleigh, with hopes of new discov'ries fir'd, And all the depth of human wit inspir'd, Mov'd o'er the western world in search of fame, Adding fresh glory to Eliza's name."

D. King. 


\section{BIRTH.}

Dittany.-Origumum Dictamus.

"A branch of healing dittany she brought, Which in the Cretan fields with care she sought."

Virgil.

This plant, so celebrated for having been selected by Venus for the cure of Aneas, is presented as the symbol of nativity or birth; perhaps from the phenomenon in its natural history. These flowers exude a viscid juice, which towards the evening exhales in vapour or gas, and which is so ignitible, that the smallest flame will set it in a blaze, which runs over the whole plant without causing the least injury.

"Contemplez cette fraxinelle, Lors qu'Apollon fuit sous les eaux, A còté de sa tige frêle Agiter d' imprudens flambeaux ;

A l' instant sa robe légère S' embrâse, étincell de feux, Et le jour, inquiet, douteux, Croit encor régner sur la terre." 


\section{BLACKNESS.}

Eвony.-Diospyros Ebenum.

"Oft by the winds extinct the signal lies,

Ere night has half roll'd round her ebon throne."

Gay.

"Black as ebony!

She abated me of half my train;

Look'd black upon me."

King Lear.

\section{BLUNTNESS OR ROUGHNESS OF MANNERS.}

$$
\text { Borage.-Borago. }
$$

"Ego borago gaudia semper ago."

This stimulating plant, has its stalks and leaves covered with a rough hairy substance, and is therefore chosen for this emblem. Pope says,

"'Tis not enough your counsel still be true:

Blunt truths more mischief than nice falsehoods do." 


\section{BLUSHES.}

Marjoran.-Origanum.

"Bind your brows with the flowers of sweet smeling marjoram."

Catullus.

The scaly leaves of some species of marjoram are delicately tinged with red, as when the blood is suddenly sent into the cheeks of youth.

$$
\text { "I have mark'd }
$$

A thousand blushing apparitions

To start into her face ; a thousand innocent shames."

Shakspeare. 


\section{BOASTER.}

Hydrangea.-Hydrangea Hortensis.

"No more delays, vain boaster! but begin;

I prophesy beforehand I shall win :

I'll teach you how to brag another time."

Dryden.

This Chinese Guelder rose is presented as the emblem of a boaster, because its magnificent flowers are never succeeded by fruit, thus resembling the vaunting words of a braggadocio, which are not followed by suitable results.

"Who knows himself a braggart,

Let him fear this; for it will come to pass, That every braggart shall be found an ass."

Shakspeare. 


\section{BOLDNESS.}

PINL.

"Yon verdant pines, that midst the winter smile, Offspring of Scotia or Virginia's soil."

Delille.

These hardy offsprings of bleak and snowy mountains are made symbolical of boldness from the resistance they make to the rigour of the storms.

True boldness (according to Locke) is the power to speak or do what we intend, before others, without fear or disorder. 

Floral Emblems

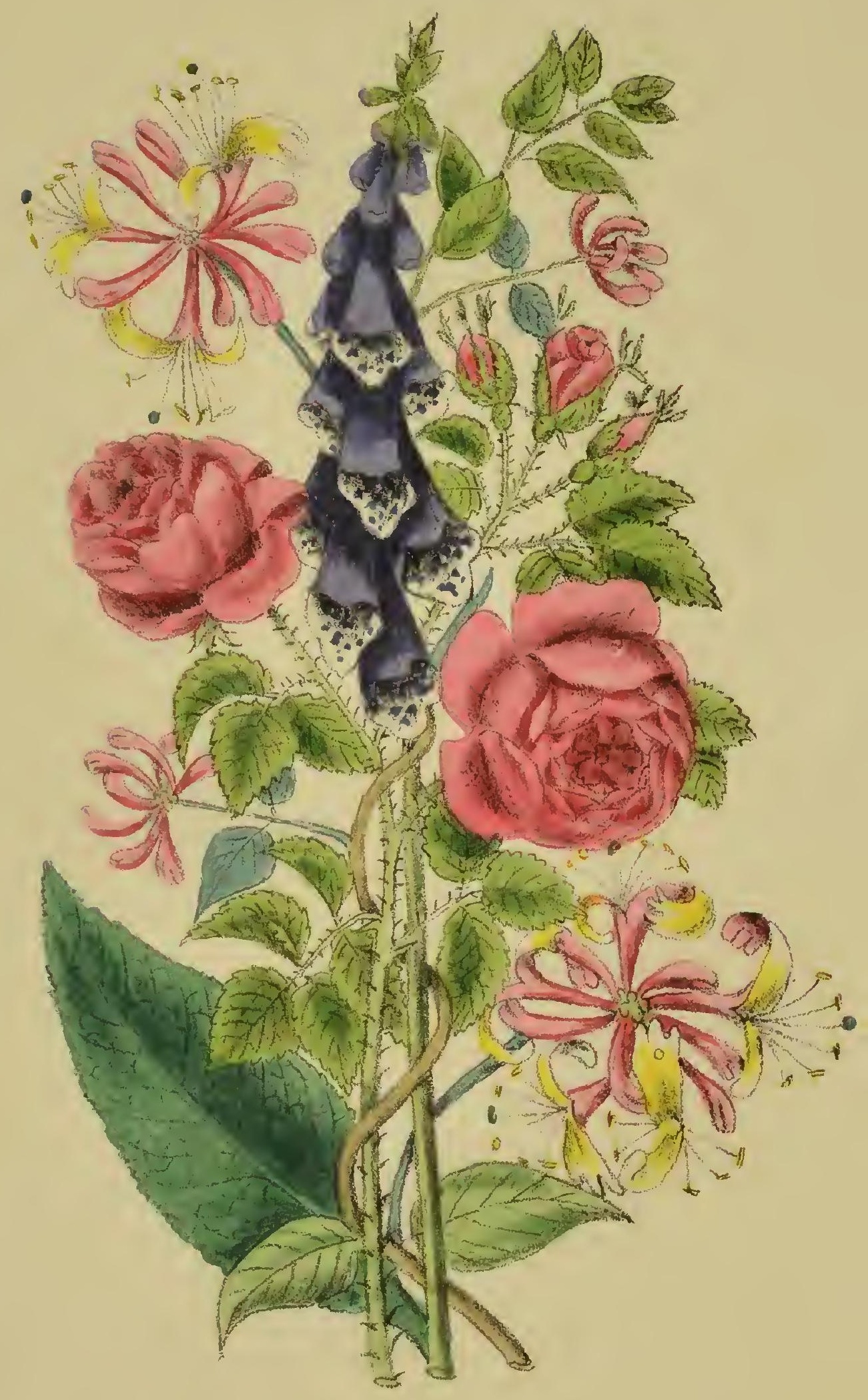

Youth and.Beauty wonted by the Bonds of Love 


\section{BOND OF LOVE}

HONEYSUCKLE OR WOODHINE.-Lonicera.

"So doth the woodbine, the sweet honeysuckle Gently entwine."

This happy emblem reminds us that sweetness of disposition is a firmer tie than dazzling beauty.

"Copious of flowers, the woodbine, pale and wan, But well compensating her sickly looks With never cloying odours, early and late."

Cowper.

\section{BULKINESS.}

Water Meton.-Melo Citrullus.

This fruit, which flourishes and swells to a great size in the sands of Egypt, is made symbolical of bulkiness.

The murmuring Israelites exclaimed, "We remember the fish which we did eat in Egypt freely; the cucumbers and the melons." 


\section{CALM REPOSE.}

BuCKBean.-Menyanthes.

" Every pilot

Can steer the ship in calms; but he performs The skilful part, can manage it in storms."

Denham.

This aquatic plant, avoiding the rapid streams, seeks recesses where the unruffled waters will allow its flowers to float in calm repose.

$$
\text { "Th' hour }
$$

Of night, and of all things now retir'd to rest, Mind us of like repose."

Millon.

\section{CALUMNY.}

MADDER.-Rubia tinctorum.

"Be thou as chaste as ice, as pure as snow, Thou shalt not escape calumny."

Shakspeare.

This plant, that is so essential to dyers and calico-printers, is made the emblem of ca- 
lumny, since it leaves so permanent a stain on the purest cloth.

L'Estrange says, "He that would live clear of the envy and hatred of potent calumniators, must lay his finger upon his mouth, and keep his hand out of the ink-pot."

\section{CANDOUR AND INNOĊENCE.}

Sweet White Violet.- Viola odorata.

"The daughters of the flood have search'd the mead For violets pale."

\section{Virgil.}

This flower, that delights us so much by its innocent perfume and spotless purity, is also made to represent a third virtue. A sonnet of the sixteenth century says,

"Violet is for faithfulnesse,

Which in me shall abide;

Hoping likewise that from your heart

You will not let it slide."

"The bond that knits together and supports all compacts, is truth and faithfulness."-I.owth. 


\section{CAPRICIOUS BEAUTY.}

Musi Rose.-Rosa moschata.

"Their passions move in lower spheres, Where'er caprice or folly steers."

Swift.

This Barbary rose seems to have thrown off its vegetable fragrance in favour of animal perfume;

"And each inconstant breeze that blows, Steals essence from the musky rose."

\section{CELIBACY.}

Rosebay Willow Herib, or French Willow. Epilobium Angustifolium.

The French call this plant Laurier Saint Antoine, after St. Antony, the first founder of monastic institutions; and we have therefore made his favourite flower the emblem of celibacy. 
Reason seems to tell us, that the most devout and strict celibacy cannot be so acceptable to the Almighty as the faithful observance of the duties of husband and wife, parent, child, and neighbour.

\section{CHARITY.}

TURNIP.-RKayu.

"Tumips hide their swelling heads below."

Gialy.

Peacham pictures the month of November with bunches of parsnips and turnips in his right hand; and Guillim says, turnips were used in armorial bearings to represent a person of good disposition, who relieved the poor. Hence we have made it the emblem of charity:

"Oh, charity! our helpless nature's pride,

Thou friend to him who knows no friend beside: 
Thine are the ample views, that unconfin'd Stretch to the utmost walks of human kind; Thine is the spirit that with widest plan Brother to brother binds, and man to man!"

Bowles。

\section{CHASTE LOVE.}

Acacia.-Robinia Pseudacacia.

" Light-leaved acacias, and the shady plain, And spreading cedar, grace the woodland reign."

The beautiful blossoms of this North American tree are made the emblem of chaste love, because the young Americans declare their first passion by presenting a branch of these papilionacious flowers to those whom Cupid directs their choice.

"Ev'n here, where frozen chastity retires, Love finds an altar for forbidden fires."

Pope. 


\section{CHASTITY.}

Orange Flowers.-Citrus Aurantium.

"The punic granate op'd its rose-like flow'rs, The orange breath'd its aromatic pow'rs."

Swift.

These fragrant blossoms are made the emblem of chastity from the purity of their white petals. One of the principal beauties of the orange tree consists in its bearing fruit and flowers at the same time, as is beautifully noticed by Pope :

"Here orange trees with blossoms and pendants shine, And vernal honours to their autumn join ; Exceed their promise in the ripen'd store, Yet in the rising blossom promise more."

Chastity is also represented by a branch of the shrub called. Chaste tree. Vitcx, or Agrnus Castus.

" Diana, goddess of chastity, And, for because that she a maiden is, 
Into hire hand the branch she bereth this, That agmus castus men call properly, And all the ladies in hire company."

Chancer.

\section{CHEERFULNESS IN OLD AGE.}

Michaeluas Daisy.-Aster Trudescanti.

We present these flowers as the happy emblem of cheerfulness in old age, since, like that blessing, it lengthens the summer of our days, and contributes towards the enlivening of all who compose its circle.

"At sight of thee my gloomy soul cheers up;

My hopes revive, and gladness dawns within me." A. Philips.

By the assistance of the plants of China and Florida, the reign of Flora is considerably lengthened in this climate; and the later months are clad with great beauty, whereas formerly,

"All green was banish'd, save of pine and yew, That still display'd their melancholy hue;

Save the green holly, with its berries red, And the green moss, that o'er the gravel spread." 


\section{CHEERFULNESS UNDER ADVERSITY.}

\section{Chinese Chrysanthemum.}

Chrysanthenum Indicum.

"A merry heart doth good like a medicine; but a broken spirit drieth the bones." Proverbs xvii. 22.

Cheerfulness is the best shield that can be found to lighten the strokes of adversity.

This flower, that gives so much cheerfulness to the parterre, when nearly all the other children of Flora have withdrawn their smiles, is presented as the emblem of this enviable disposition. 


\section{CHILDISHNESS.}

Butrer-cues.-Ranunculus bulbosus.

"And daisy there, and cowslip too, And butter-cups of golden hue, The children meet as soon as sought, And gain their wish as soon as thought ; Who oft, I ween, the children's way, Will leap the threshold's bounds to play."

Village Minstrel.

This flower, which so gaily bedecks our meadows with its golden petals, and enters so frequently into the sports of infancy, is presented as a meet emblem of childishness.

Locke says, "The actions of childishness, and unfashionable carriage, time and age will of itself be sure to reform." Let us not therefore shorten the happy days of butter-cups, or exclaim in the words of Gay,

" Let weeds, instead of butterflow'rs appear; And meads, instead of daisies, hemlock bear.". 


\section{COLD-HEARTED.}

LetTuce.-Lactuca.

"Fat colworts, and comforting purseline, Cold lettuce, and refreshing rosemarine."

Spencer.

It is fabled, that after the death of Adonis, Venus laid upon a bed of lettuce.

"And now let lettuce, with its healthful sleep, Make haste, which of a tedious long disease The painful loathings cures."

Columella. 


\section{COMPLAISANCE.}

Common ReEd.-Arundo phragmites.

"Mincius, with wreaths of reeds his forehead cover'd o'er."

Eneis.

This grass of the rivers, which bends so readily with the current, is made the type of a pliant disposition :

"Pliant and warm may still her heart remain, Soft to the print, but ne'er turn hard again."

A dried reed is symbolical of a shrill scolding voice.

"I'll speak between the change of man and boy With a reed voice."

Shakspeare. 


\section{CONCEALED MERIT.}

CORAANDER.-Coriundrum.

"Isracl called the name thereof manna; and it was, like coriander seed, white."

Exodus xiii. 31.

The seeds of the coriander were formerly esteemed one of the best carminative medicines; and they were generally given to women and children under the concealed form of comfits; hence the emblem.

None enrich their country more than those who bring concealed merit into notice. 


\section{CONFIDENCE.}

Hepatica, or Noble Liver Wort.-Anemone Hepatica.

" Here blushing Flora paints th' enamell'd ground, Where frosts have whiten'd all the naked groves."

Pope.

This beautiful little flower is made the emblem of confidence, because it dares the rigours of the season.

"Say, lovely gem, why dost thou come

So early in the year?

When no flowers beside thee bloom, And through the clouds and winter's gloom, The sun-beams scarce appear."

\section{CONJUGAL FIDELITY.}

Lime, or Linden Tree.-Tiliu.

"And the lime at eve

Diffusing odours."

Cowper.

It is not easy to surmise why the linden tree is made the representative of this blessing. 
Some suppose it to be on account of its formerly being so frequently planted in the front of houses to shade happy couples from the noon-tide sun.

A botanical wag observed that each bunch of flowers had but one tongue between them.*

"He mark'd the conjugal dispute;

Nell roar'd incessant, Dick sat mute."

Swift.

\section{CONSOLATION.}

SNOW-DROP.-Galanthus nivalis.

"A flow'r that first in this sweet garden smil'd, To virgins sacred, and the snow-drop styl'd."

Tickell.

The snow-drop is the first flower that awakes from the repose of winter, and cheers us with

* The flour-stalk springs from, and is attached to a whitish, tongue-shaped leaf, widely different both in colour and shape to the foliage of the tree. 
the assurance of the reanimation of nature; and hence it has been made the emblem of consolation.

"Then, spirit flower, I'll pluck thy bell, An offering for my breast;

And when ills come or passions swell, Thy prophet flowers each storm shall quell And give it promis'd rest."

The Romish church dedicated the snowdrop to the Purification of the Virgin Mary.

\section{CONSOLATION TO THE SICK.}

$$
\text { Poppy.-Papaver. }
$$

"And poppies, which bind fast escaping sleep."

Columella.

In floral language, the poppy is made the symbol of consolation to the sick, since it procures ease and sleep to the restless invalid.

"From the Poppy I have ta'en Mortals balm, and mortals bane! 
Juice, that creeping through the heart,

Deadens every sense of smart."

Mrs. M. Robinson.

Fertility was hieroglyphically described by Venus, with a head of poppy in her hand.

\section{CONSTANCY.}

Blue Pyramidal Bell Flower.

Campanula pyromidalis.

"There thou shalt cull me simples, and shall teach Thy friend the name and healing pow'rs of each, From the tall bluc-bell to the dwarfish weed, What the dry land, and what the marshes breed."

Millon.

The blue campanula is made emblematical of constancy on account of its colour. South describes constancy as a stability and firmness of friendship, which overlooks and passes by lesser failures of kindness, and yet still retains the same habitual goodwill to a friend. 


\section{COQUETRY.}

Yellow Day Lily.-Hemerocallis Flava.

Belle d'un jour of the French.

"Aux feux dont l'air étincelle S'ouvre la belle de jour;

Zephir la flatte de l'aile:

La friponne encor appelle

Les papillons d'alentour.

Coquettes, c'est votre emblème :

Le grand jour, le bruit vous plait, Briller est votre art suprême;

Sans éclat, le plaisir même

Devient pour vous sans attrait."

Philippon de la Madeleine.

This fragile beauty is made the emblem of coquetry, because its flowers seldom last a second day.

"The light coquettes in sylphs aloft repair, And sport and flutter in the ficlds of air."

Pope. 
Flonal Fimblems

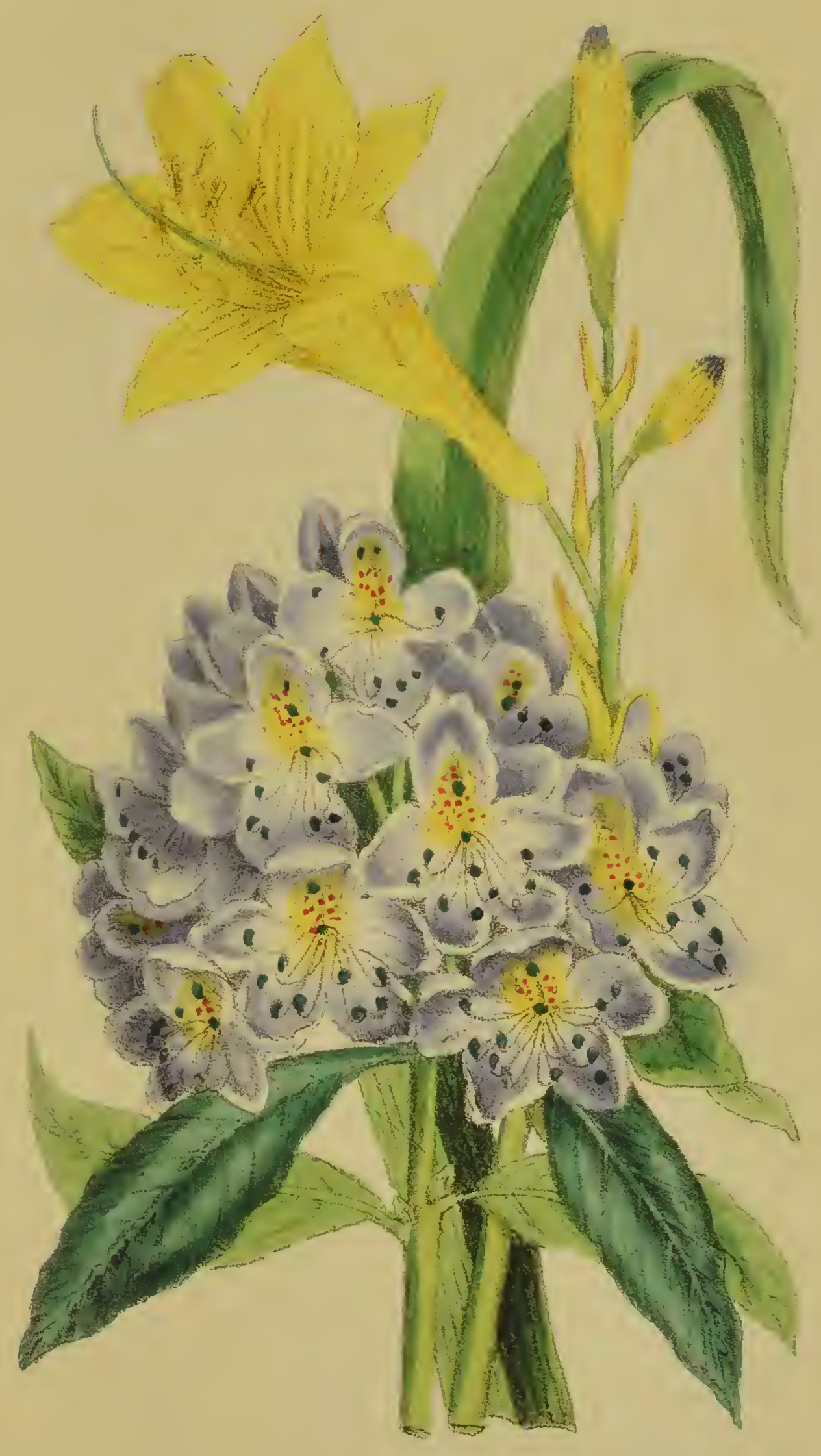

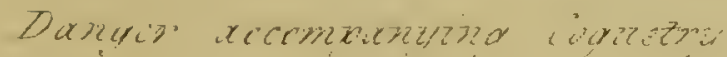

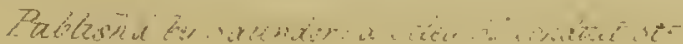





\section{COURAGE.}

Brack Poplar.-Populus nigra.

"A double wreath Evander twined,

And poplars black and white his temples bind."

\section{Virgil.}

The poplar was dedicated to Hercules, in consequence of his destroying Cacus, in a situation where these trees abounded.

"When Teucer from his sire and country fled, With poplar wreaths the hero crown'd his head."

IIorace, Ode 7.

\section{CRAFTINESS.}

Sweet-william.-Dianthus Barbatus.

"Siveet-william small has form and aspect bright, Like that sweet flower that yields great Jove delight."

Cowley.

This species of pink, possessing none of the fragrance of its relatives, has had its flowers 
so artfullý grouped by nature, as to attract our admiration; and it is as frequently made the symbol of gallantry as of craftiness. Of craftiness, Locke says, "Nobody was ever so cunning as to conceal their being so ; and every body is shy and distrustful of crafty men."

\section{CRIME.}

TAMARISK.-Tamarix.

" On yon rough craig,

Where the wild tamarisk whistles to the sea blast." H. Davy.

It was a custom with the Romans, to put wreaths of this flexible plant on the heads of criminals; and hence they mention it as the accursed or unhappy tamarisk, from which we have devised the emblem.

Criminal love engenders deeds of wickedness that too frequently deserve the wreath of tamarisk. 


\section{CRITIC.}

Squirting Cucumber.-Momordica Elaterium.

"Now learn what mortal criticks ought to show, For 'tis but half a judge's task to know." Pope.

This plant, which produces that rough and powerful cathartic medicine called elaterium, is made the emblem of a critic. When in skilful hands, both the juice of this squirting fruit, and the ink which descends from the pen of the critic, become beneficial; but there are some, of whom Pope says,

"Criticks I saw, that others' names deface, And fix their own with labour in their place." 


\section{CRUELTY.}

Strnging Nettue.-Urica pilulifera.

"And rampant nettles lift the spiry head."

Bloomfield.

"Some so like to thorns and nettles live,

That none for them can, when they perish, grieve."

Waller.

The nettle carries its cruel venom in a bag at the base of the sting, always ready to perforate the incautious, and throw in its vegetable poison, which, like slander, attacks even the brave when it can act slyly. But, neither the sting of the nettle, nor the tooth of a viper is so much to be dreaded as the tongue of a slanderer. 


\section{A CURE.}

Batm.-Melissa.

"And balm that never ceases uttering sweets."

Without possessing a knowledge of medicine, there are none so poor but they may bestow balm.

"A tender smile, our sorrow's only balm."

Young. 


\section{DANGER.}

Rhododendron.-Rhododendron.

" O'er pine-clad hills, and dusky plains, In silent state rhododendron reigns, And spreads, in beauty's softest blooms, Her purple glories through the glooms."

Shaw.

These purple flowers abound in a poisonous honey, and have hence been made emblematical of the dangers that lurk about the imperial purple.

"Ev'n as those bees of Trebizond,--

Which from the sunniest flowers that clad With their pure smile the garden round,

Draw venom forth that drives men mad."

T. Moore. 


\section{DANGEROUS INSINUATION.}

Great Bindweed.-Convolvulus Sepium.

"Regardez : ce beau liseron

Desine sa légère cloche

A travers cet épais buisson

Dont l' épine défend l' approche."

We have added this attractive wild flower, and its entwining branch to the hieroglyphical language of flowers, as the emblem of a dangerous insinuation, because when once permitted into the parterre it cannot easily be eradicated, and frequently causes destruction to its neighbouring plants.

Hooker observes "There is no particular" evil which hath not some appearance of goodness, whereby to insinuate itself." 


\section{DAUNTLESSNESS.}

Thrift, or Sea Pink.-Statice Armeria.

This plant, which seeks the sea shore, and

"Stems the bold torrent with a dauntless breast."

is presented as the emblem of dauntlessness, since it resists the threatening storms and cutting blasts from the ocean, as well as the boisterous winds of the mountains.

\section{DEATH AND ETERNAL SORROW.}

Cypress Tree.-Cyparissus or Cupressus.

"The mournful cypress rises round, Tap'ring from the burial ground."

\section{Lucan.}

This tree has been dedicated to sorrow and death in all civilized countries, and in all 
ages from the destruction of Troy to the present day.

"In mournful pomp the matrons walk the round, With baleful cypress and blue fillets crown'd, With eyes dejected, and with hair unbound."

Eneis, Book 3.

\title{
DEATH SAID TO BE PREFERABLE TO THE LOSS OF INNOCENCE.
}

\author{
A WHITE ROSE DRIED.
}

"Of the fourth Edward

* * * * * * * *

He rent the crown from vanquish'd Henry's head, Rais'd the white rose, and trampled on the red."

Waller.

"What comfort does overflow the devout soul, from a consciousness of its own innocence and integrity!" 


\section{DECEITFUL CHARMS.}

THORN-APPLE.-Datura Stramonium.

This dangerous narcotic plant clothes itself with such an elegant indented foliage, and garnishes its branches with carollas of so graceful and negligent a shape, and of so pure a white, that all suspicion of its deleterious nature seems lulled to rest. Whilst like the lamiæ of old, its charms only allure that its power may destroy; and hence, in symbolical language, the datura is made the emblem of deceitful charms, and the common stramonium is made to express disguise.

"Hence guilty joys, distastes, surmises, False oaths, false tears, deceits, disguises."

Pope. 


\section{DECEITFUL HOPE.}

Daffodil.-Narcissus Pseudo.

"When early primroses appear,

And vales are deck'd with daffodils, I hail the new reviving year,

And soothing hope my bosom fills."

Williams.

Fable tells us that Proserpine was gathering daffodils when seized by Pluto.

"Sweet hope! kind cheat! fair fallacy by thee We are not where or what we be;

But what and where we would be; thus art thou Our absent presence, and our future now."

Crashaw.

In the Romish church, this flower is dedicated to St. Perpetua. The Petticoat Daffodil, Narcissus Bulbocodium, is dedicated to St. Catherine; and the Nodding Daffodil, Narcissus nutans, to St. Julian. 


\section{DECEPTION.}

Winter Cherry.-Physalis Alkeketgi.

We present this berry as the emblem of deception, since it assumes all the beauty of the cherry, in shape, gloss, and colouring.

One of Shakspeare's songs says,

" Sigh no more, ladies, sigh no more;

Men were deceivers ever :

One foot in sea, and one on shore;

To one thing constant never."

\section{DECLARATION OF LOVE.}

Tulip.-Tulipa.

"Then comes the tulip race, where beauty plays Her idle freaks."

Thompson.

"There's fairy tulips in the east, The garden of the sun;

The very streams reflect the hues, And blossom as they run."

Wiffen.

The tulip has from time immemorial been 
Floral Ermblems

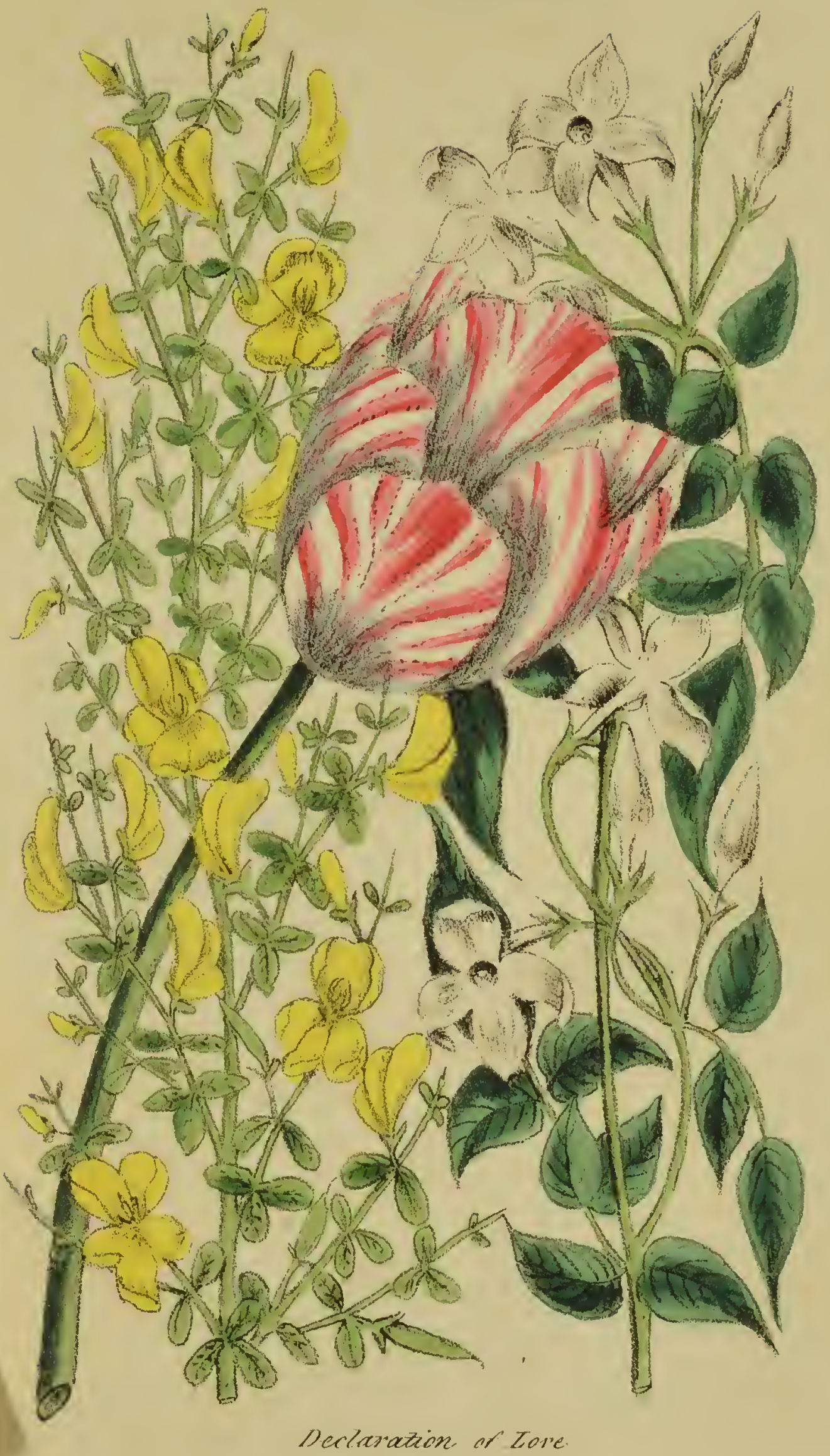

from Irumilien to Amixbilicy

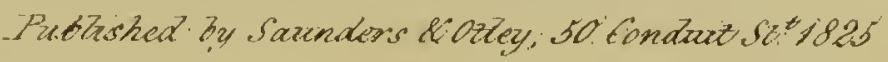



made the emblem by which a young Persian makes a declaration of love.

Chardin tells us, that when a Persian presents a tulip to his mistress, it is his intention to convey to her this idea, that like this flower, he has a countenance all on fire, and a heart reduced to a coal.

"Good shepherd, tell this youth what 'tis to love. It is to be made all of sighs and tears ;

It is to be made all of faith and service ;

It is to be made all of fantasy,

All made of passion, all made of wishes ;

All adoration, duty and obedience;

All humbleness, ail patience, all impatience, All'purity, all trial, all observance.

Shakspeare.

\section{DEFENCE.}

\section{Privet.-Ligustrum}

This shrub is made the emblem of defence from its being so frequently planted in garden hedges as a protection to tender plants. 


\section{DELICACY.}

Buue Bottle Centaury.-Centanea Cyamus.

"There is a flower, a purple flower

Sown by the wind, nursed by the shower,

O'er which Love has breathed a power and spell

The truth of whispering hope to tell.

* * * * * * *

And with scarlet poppies around like a bower,

Found the maiden her mystic flower.

Now, gentle flower, I pray thee tell

If my lover loves me, and loves me well;

So may the fall of the morning dew

Keep the sun from fading thy tender blue."

L. E. L.

This beautiful corn flower, the subject of the above verses, is made the emblem of delicacy from the purity of its celestial colour, which is not equalled by the finest ultramarine, and scarcely surpassed by the azure veins of youthful beauty. 


\section{DELICATE PLEASURE.}

Sweet-pea.-Lathyrus Odoratus.

"Here are sweet-peas on tip-toe for a flight, The wings of gentle flush, o'er delicate white, And taper fingers catching at all things To bind them all about with tiny rings."

Keats.

From the charms this flower displays both in fragrance and colour has arisen the emblem.

"These delicacies,

I mean of taste, sight, smell, herbs, fruit, and flow'rs."

Milton.

\section{DESIRE.}

Jo N QU I L.--Narcissus Jonquilla.

"Jonquils,

Of potent fragrance."

\section{Thompson.}

This odorous species of Narcissus stands in floral language as emblematical of desire.

"Desire's the vast extent of human mind; It mounts above, and leaves poor hope behind." 


\section{DESIRE TO PLEASE.}

Mezereon.-Daphne Mezereum.

"Mezereon too,

Though leafless, well attired, and thick beset

With blushing wreaths, investing every spray."

Cowper.

In floral language, this early flowering shrub is made to express a desire to please, whilst others make it one of the emblems of coquetry, comparing it to a nymph, who in the midst of winter seeks admiration in her summer robes.

"Leave such to trifle with more grace and ease, Whom folly pleases, and whose follies please."

Pope. 


\section{DESPAIR.}

MARYGOLD.-Calendula Officinalis.

"As emblem of my heart's sad grief, Of flow'rs, the marigold is chief."

The petals of this flower were formerly in high repute, as a cordial medicine for raising the spirits and lessening the too violent palpitation of the heart; and being given to those in despair it became the emblem of that malady.

Despair sometimes takes the character of frenzy, and at others, that of low desponding indolence.

"The wretch whase doom is, 'hope nae mair,'

What tongue his woes can tell!

Within whase bosom, save despair,

Nae kinder spirits dwell."

Burns. 


\section{DIFFICULTY.}

\section{Black-thorn.-Prumus spinosa.}

$$
\text { " or sloes austere, }
$$

Hard fare! but such as boyish appetite Disdains not."

Cowper.

It is difficult to penetrate a thick fence of black-thorn; some persons make a difficulty of walking over a heath, others who mistake impossibilities for difficulties, can only be convinced by conviction, which frequently comes too late. 


\section{DIFFIDENCE.}

\section{CYCLAMEN.-Cyclamen.}

As modest diffidence adds attractions to beauty, so does this graceful flower engage our notice by its unassuming carriage, for the cyclamen, although it expands its petals in an upright direction, never rears its head to the sun.

We present this emblem with a hope that the poets will not longer remain too diffident to let this pretty plant escape the harmony of their song, since we cannot find a line to form a motto, or grace the floral symbol of diffidence.

"Distress makes the humble heart diffident"

The church has dedicated this flower to St. Romuald. 


\section{DIGNITY.}

Laurel-leaved Magnolia.-Magnolia grandiflora.

The grandeur of this flower is appropriate to the elevated station which it takes in the vegetable kingdom, for in its native soil it advances itself above the forest trees, displaying its dignity, and dispensing its fragrance throughout the woods of Florida.

It is remarked by an elegant writer that " some men have a native dignity, which will procure them more regard by a look, than others can obtain by the most imperious commands." 


\section{DISDAIN .}

Yellow Carnation.-Dianthus Caryophyllus.

"Bring coronations, and sops in wine, Worn of paramours."

Spencer.

This variety of the carnation is more acceptable to the florist than to the lover, since yellow stockings are not so much coveted by us as yellow boots are by the unfortunate Greeks. One of the first acts of the late Sul$\tan$ Selim's reign, was to cut off the head of a common Greek whom he met when incognito, wearing yellow slippers: he staid to see the execution performed. Yet so vain are the Greeks, that they will run this fatal risk in order to be taken for their betters. Shakspeare says,

Feed arrogance, and are the proud man's fees." 


\section{DISGUST.}

Frog Ophrys.-Habenaria viridis.

"No more shall violets linger in the dell, Or purple orchis variegate the plain."

Mrs. C. Smith.

From the resemblance which this curious flower is thought to bear to the frog, it has been made the emblem of disgust.

"Those unenlarged souls are disgusted with the wonders which the microscope has discovered."-Watts. 



\section{Floral Emblems}

Desire not Popular 'Pxirum: \& Dristinctuon

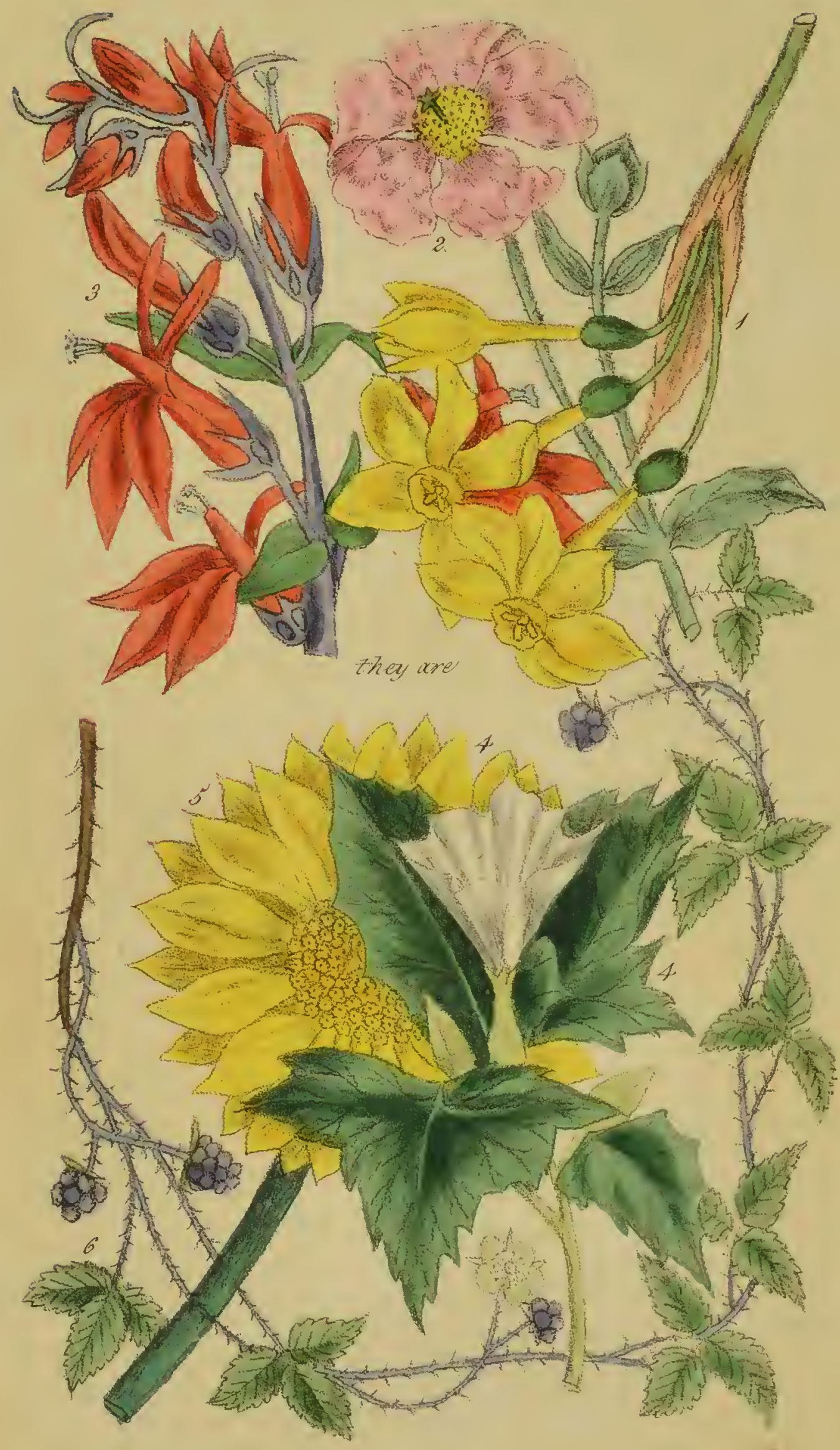

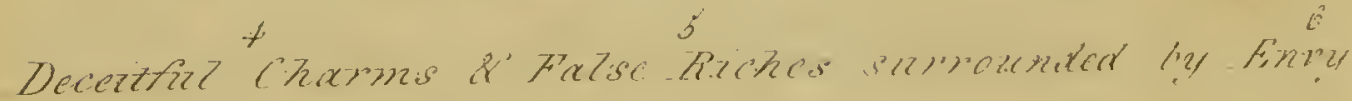

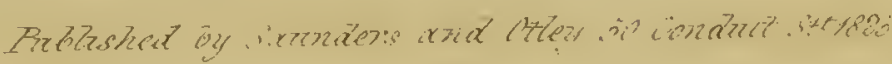




\section{DISTINCTION.}

Cardinal's Flower.-Lobelia Cardinalis.

"You hold a fair assembly;

You are a church-man."

Shakspeare.

This beautiful Mexican plant obtained the name of cardinal's flower from the bright red colour of its corollas, on which account we place it as the symbol of distinction.

"In the wind and tempest of fortune's frown, Distinction, with a broad and powerful fan, Puffing at all, winnows the light away."

Shakspeare. 


\title{
DOCILITY .
}

\author{
RusH.-Juncus.
}

"A shaggy goat's soft hide beneath him spread, And with fresh rushes heap'd an ample bed."

Odyssey.

This plant, so proverbial for its pliability, is the symbol of docility.

"Soon docile to the secret acts of ill, With smiles I could betray, with temper kill."

Prior.

Those pliable minds which bend to every will, are never worth a rush! 


\section{DO NOT ABUSE.}

\section{SafFron Flower.-Crocus sativus.}

—_ "Can Timolus' head

Vie with our saffron odours?"

Philips.

Too liberal a use of this cordial and stimulating flower, is said to destroy the reason, or cause the death of those who indulge in it.

". Some praise at morning, what they blame at night;

But always think the last opinion right."

Pope. 


\title{
DRUNKENNESS.
}

\author{
VIN E.-Vitus.
}

" Great father, Bacchus, to my song repair;

For clust'ring grapes are thy peculiar care:

* * * * * * *

Come strip with me, my god; come drench all o'er, Thy limbs in musk of wine, and drink at ev'ry pore."

This emblem requires no explanation, and our only remark on a drunkard will be the words of Shakspeare.

"O monstrous beast! how like a swine he lies." 


\section{DURABILITY.}

Dogwood, or Cornel Tree.-Cormus.

" His cornel spear

Ulysses wav'd, to rouse the savage war."

Odyssey.

The firm and lasting nature of this wood has caused it to be made the type of duration.

"Fix'd in the wood th' Italian cornel stood." Eneis. 


\section{EARLY YOU'TH.}

\section{Primrose.-Primula.}

"And here's the meek

And soft-ey'd primrose."

\section{Hurdis}

The age between childhood and womanhood is represented by this early blossom, whose delicate perfume and modest colour so agreeably attend the path to summer.

"Youth is the vision of a morn, That flies the coming day:

It is the blossom of the thorn,

Which rude winds sweep away.

'Tis like the charming hue that glows

Upon a virgin's face ;

Till care hath nipp'd her fading rose,

And wither'd every grace."

Cunningham.

The common primrose is dedicated to St. Agatha; the red variety, aculis, to St. Adelaide; the early red, Verna rubra, to St. Theodora; and the polyanthus to St. Catehrine de Ricci. 
Floral Fimblems

in

(1)

क की

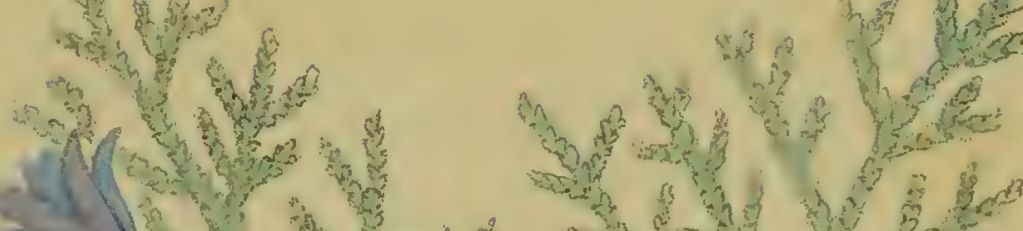

क्री

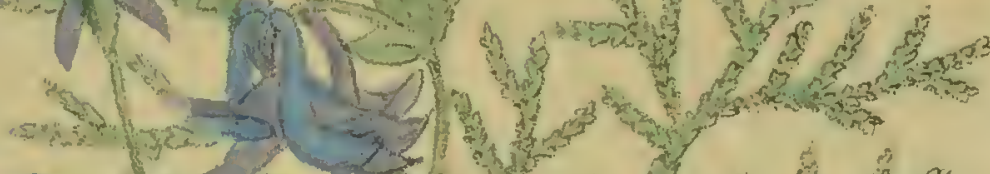

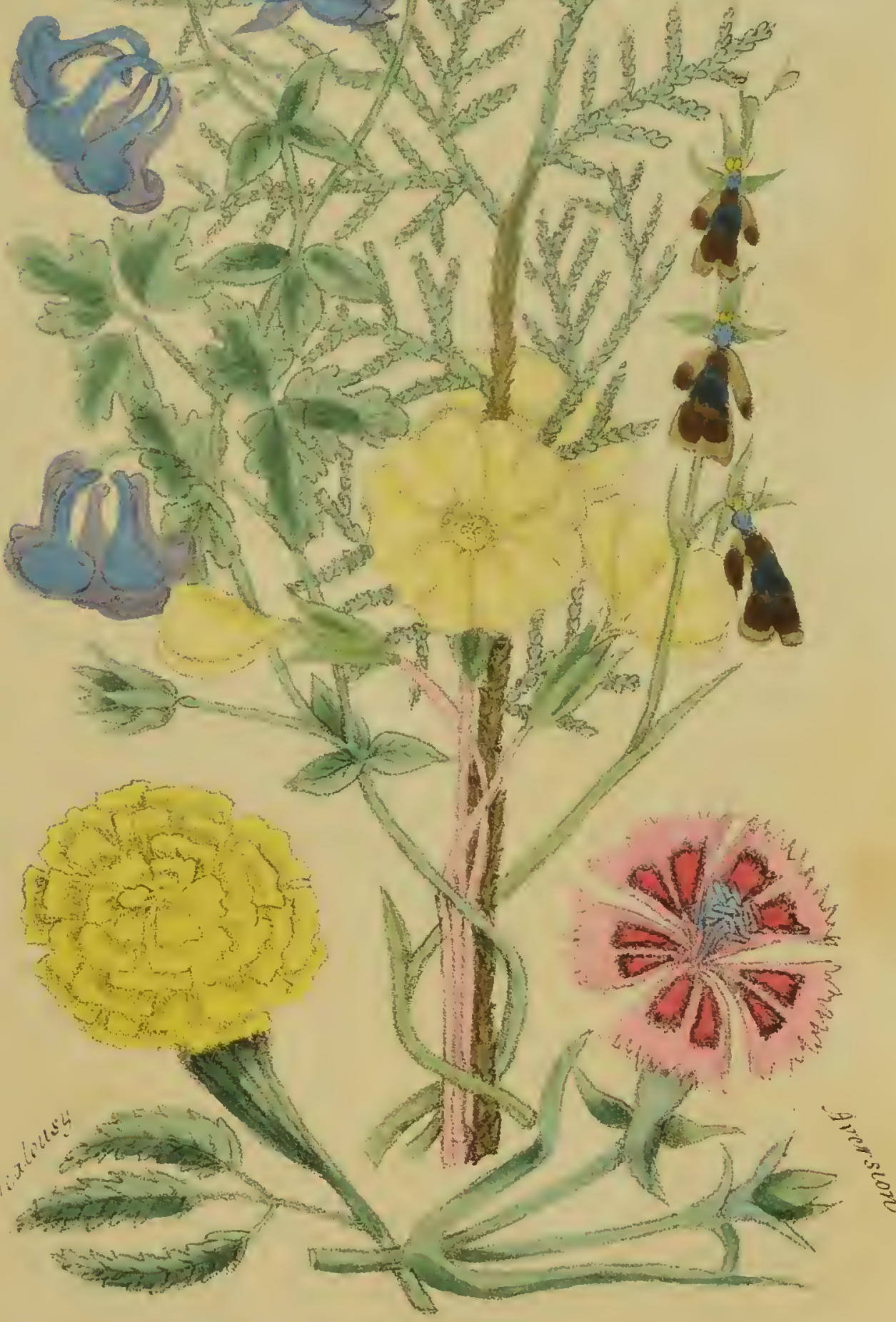

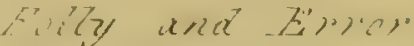

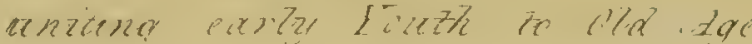





\section{EGOTISM AND SELF-LOVE.}

Narcissus.-Narcissus.

"Narcissus fair,

As o'er the fabled fountain hanging still."

Thompson.

From Ovid's beautiful metamorphosis of the lovely and coy Narcissus into this flower has originated the emblem.

"Narcissus on the grassy verdure lies:

But whilst within the crystal font he tries

To quench his heat, he feels new heats arise.

For as his own bright image he survey'd, He fell in love with the fantastic shade; And o'er the fair resemblance hung unmov'd: Nor knew, fond youth! it was himself he lov'd.

This flower is dedicated to St. Apollonia. 


\section{ELEGANCE.}

Rose Acacia.-Robinia hispida.

"Graceful to sight, and elegant" hang the papilionaceous blossoms of this favourite flowering shrub.

Beauties are frequently seen without elegance, but elegance is composed of beauties.

" Graceful ease, and sweetness void of pride, Might hide her faults, if belles had faults to hide."

Pope. 


\section{ELEVATION.}

Silver Fir.-Pimus Picea.

_ "Towering firs in conic forms arise, And with a pointed spear divide the skies."

Prior.

Nature has adapted this tree to its mountainous birth-place, so that it resists

$$
\text { " the storm, }
$$

That makes the high elm couch, and rends the oak. A thousand blows,

That shake the lofty monarch on his throne, We lesser folks feel not. Keen are the pains Advancement often brings."

Hurdis. 


\section{ELOQUENCE.}

IRIS OR Flag-Flower.-Jits.

"Iris, on saftion wings array'd with dew

Of various colours, through the sun-beams flew."

Virgil.

The ancients represented eloquence by the species of this flower which grows in the waters, whose various colours harmonize as delightfully to the eye as fine oratory does to the ear.

Our immortal bard observes that the eyes of the ignorant are more learned than their ears.

\section{EMBARRASSMENT.}

Love in a Puzzle.-Nigella Damascena.

These pretty flowers being seated in a chevaux-de-frise of liner foliage, has induced 
us to present them as emblematical of embarrassment.

Love is a puzzle which embarrasses all who fall into it, yet Anacreon says,

"Nay, should they take his chains away, The little captive still would stay."

\section{ENVY.}

Common Bramble.-Rubus fruticosus.

"The bush my bed, the bramble was my bow'r." Spencer.

This rough and prickly trailing plant is made the emblem of this unhappy disposition, because it carries thorns in its bosom. Pope says

“Envy, to which th' ignoble mind's a slave, Is emulation in the learn'd or brave." 


\section{ERROR.}

FLy ORChis.-Ophrus muscifera.

"Why do'st thou show to the apt thoughts of men, The things thou art not?"

\section{Shakspeare.}

This plant is made the emblem of error, because Flora seems to have sprinkled the stem with flies instead of flowers.

"As conscious that affection grows, Pleas'd with the pencil's mimic power; That power with leading hand she shows, And paints a fly upon a flower."

Langhorn. 


\section{ESTEEM.}

Garden SAGE.-Salva officinalis.

This plant was so highly esteemed by the school of Salernum, that they left this verse in allusion to its virtues.

"Cur moriatur homo cui salvia crescit in horto?"

Why should a man die while he has sage in his garden? 


\section{EXTINGUISHED HOPES.}

Convolvulus Major.-Convolvulus purpreus.

"Convolvulus, expand thy cup-like flower, Graceful in form, and beautiful in hue."

This flower is given to the ladies, that when they have made their happy choice, they may have an appropriate flower to bestow on their hopeless suitors, so as to extinguish the flame their charms have created.

"The soft god of pleasures that warm'd our desires, Has broken his bow, and extinguish'd his fires."

Dryden. 


\section{FALSEHOOD.}

Bugross. - Anchusa.

"Arts on the mind, like paint upon the face, Fright him, that's worth your love, from your embrace."

Young.

The roots of this plant affording a rouge for the face, has caused it to be made the emblem of falsehood.

The faded belles exclaim with La Fontaine,

"Les ruines d'une maison

Se peuvent réparer; que n'est cet avantage

Pour les ruines du visage?" 


\section{FALSE RICHES.}

\section{SUN-FLOWER.-Helianthus.}

"Uplift, proud sun-flower, to thy favorite orb That disk whereon his brightness loves to dwell; And as thou seem'st his radiance to absorb, Proclaim thyself the garden's sentinel."

\section{Barton.}

The sun-flower is made the emblem of false riches, because gold of itself, however abundant, cannot render a person rich who is poor in spirit.

" Let a broad stream, with golden sands

Through all his meadows roll;

He's but a wretch with all his lands,

That wears a narrow soul."

Watts. 


\section{FATE.}

FlAX (iil a green state, with the flower).-Linum.

" Courage uncertain dangers may abate;

But, who can bear the approach of certain fate?"

Dryden.

"Random chance, or wilful fate,

Guides the shaft from Cupid's bow."

A. Philips.

We learn from Pierius Valerianus, that flax was the hieroglyphic of fate among the Egyptians ; and we may presume, that the emblem originated from its use in the bow.

"The whizzing arrow sings, And bears thy fate, Antinous, on its wings."

Pope.

Peacham says, "Fate is drawn like a man in a long flaxen robe, looking upward to certain bright stars compressed about with thick clouds, from whence hangs a chain of gold, which signifies the conjunction of divine with 
human things." Plato holds this chain to be the power of the divine spirit.---(See Homer's Iliad, Book VIII.)

\title{
FEAST, OR BANQUET.
}

\author{
Parsley.-A pium Petroselinum. \\ "Let parsley spread \\ Its living verdure o'er the feast."
}

Horace, 36.

The beautiful curled foliage of this plant having been used to decorate viands, from the time of Virgil's friend to the present day, has caused it to be made emblematical of a feast.

In the hieroglyphic language of flowers, the gift of parsley implies a wish of the person's death to whom it is presented; for parsley has ever been the herb with which the Greeks decorate their graves and tombs; and hence

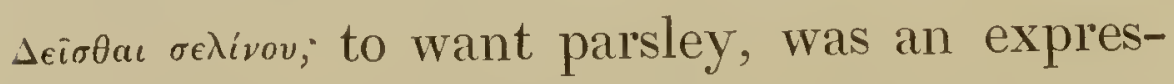
sion applied to a person at the last extremity. 


\section{FECUNDITY.}

Hollyhock.-Alcea Rosea.

"From the nectaries of hollyhocks

The humble bee, e'en till he faints, will sip."

This towering and beautiful eastern plant, which is so prolific in yielding seed, is hence made the emblem of fecundity.

\section{FELICITY.}

Sweet_Sultan, or Centaury.-Centaurea moschata.

"To cure the bees, dry'd roses, acorn juice Athenian thyme and centaury conduce."

Virgil.

This honey-smelling flower, from the Persian fields, as well as "the corn-flower blue," of our own arable lands, is made the happy emblem of felicity.

" Oh! happiness of sweet retir'd content, To be at once secure and innocent."

Denham. 


\section{FIDELITY.}

WALL SPEEDWEL.-Veronica arvensis.

This beautiful plant, that attaches itself to old walls,

"And decks his branch with blossoms over all ;"

reflecting in its petals the azure of the heavens, is made the symbol of fidelity.

Its relative, the common speedwell, veronica officinalis, which so happily covers our barren grounds with its celestial bird's-eye flowers, stands as the emblem of resemblance; the Greek name of speedwell meaning true image.

"Fairest resemblance of thy Maker fair, Thee, all things living gaze on."

Milton.

This plant is dedicated to St. Simeon of Jerusalem. 


\section{FIDELITY .}

RosemaRy.-Rosmarinus.

"I meet few but are stuck with rosemary: every one asked me who was to be married."

Noble Spanish Soldier.

Rosemary was formerly worn at weddings, to signify the fidelity of the lovers. It was also an emblem of remembrance;

"There's rosemary for you, that's for remembrance; pray you love, remember."

Ophelia.

"He, from his lass him lavender has sent, Showing her love, and doth requital crave; Him rosemary his sweetheart, whose intent Is that he her should in remembrance have."

Drayton。 


\title{
FIDELITY IN FRIENDSHIP.
}

\author{
Ivy._Ledera helix.
}

"As the ivy, when blasts howl before it,

Clasps the bough it encircles more tight;

So my heart in the storms that break o'er it,

More closely to thine shall unite.

Then come to this bosom_'tis bleeding and bare;

But the child of affliction may find a home there."

$W . W . R$.

"I love the ivy-mantled tower,

Rock'd by the storm of thousand years."

Cumningham.

This emblem of generous friendship attaches itself to the wretched:

"Thus stands an aged elm, in ivy bound, Thus youthful ivy clasps an elm around."

Parnell.

"Is aught so fair

In all the dewy landscape of the spring, The summer's noontide grove-the purple eve At harvest-home, or in the frosty morn, Glitt'ring on some smooth sea, is aught so fair As virtuous friendship?" 


\title{
FIDELITY IN MISFORTUNE.
}

\author{
W ALL-FLower.-Cheiranthus Cheiri.
}

"The rude stone fence, with fragrant wall-flow'rs gay,

To me more pleasure yield,

Than all the pomp imperial domes display."

Scott.

The wall-flower is made the emblem of fidelity in misfortune, because it attaches itself to the desolate, and enlivens the ruins which time and neglect would otherwise render terrible. It hides the savage strokes of feudal times on the castle walls ; fills the space of the wanted stone in the mouldering church, and wreathes a garland on the crumbling monument, where grateful memory no longer lingers.

"For this, obedient zephyrs bear

Her light seeds round yon turret's mould;

And, undispers'd by tempest there,

They rise in vegetable gold."

Langhorn. 


\title{
FLAME, OR PASSION OF LOVE.
}

\author{
Yellow Iris.-Pseud-Acorus.
}

"Amid its waving swords, in flaming gold The Iris towers ,"

Mrs. C. Smith.

This flag flower is made to represent-

"My heart's on flame, and does like fire To her aspire."

$$
\text { Cowley. }
$$

"No warning of th' approaching flame; Swiftly like sudden death it cameI lov'd the moment I beheld."

Granville. 


\section{FLATTERY.}

Venus's Looking-GLAss.-Campanula Speculum.

"Nothing so much intoxicates the brain

As flatt'ry's smooth insinuating bane:

She on th' unguarded ear employs her art, While vain self-love unlocks the yielding heart;

And reason oft' submits, when both invade, Without assaulted, and within betray'd."

Fenton.

The brilliant corollas of this little plant have gained it the name of Venus's lookingglass; and on this account it is made the emblem of reflection as well as of flattery.

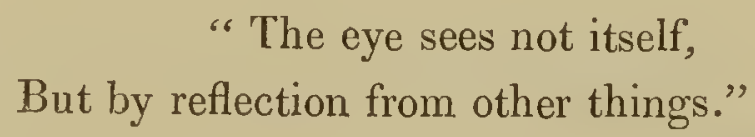

Shakspeare. 


\section{FOLLY.}

\section{Columbine.-Aquilegia.}

"And entwine

The white, the blue, the flesh-like columbine."

W. Browne.

This flower is made the emblem of folly, either on account of its party-coloured corolla, or in allusion to the shape of its nectary, which turns over like the cap of the old jesters.

The above-mentioned poet says,

"The columbine in tawny often taken,

Is then ascribed to such as are forsaken."

The foxglove having some resemblance to the cap and the bells, has induced the poets to make it also symbolical of folly.

"Love is blind, and lovers cannot see The pretty follies that themselves commit."

Shakspeure. 


\title{
FOOLISHNESS, OR SIMPLICITY.
}

\author{
Pomegranate.-Punica.
}

" And rich pomegranate, wrapt in dulcet pulp Their racy seeds."

Mason.

This emblem is probably made in allusion to Proserpine's having eaten the seeds of the pomegranate in the Elysian fields, which the poets tell us prevented her return to earth.

We have somewhere seen blindness pictured under the emblem of a young woman directing a mole with one hand, and holding a pomegranate flower in the other, as the symbol of foolishness. 


\title{
FORESIGHT.
}

\author{
HoLly.-Ilex.
}

" Fairest blossoms drop with ev'ry blast;

But the brown beauty will like hollies last."

Gay.

The holly or holm is made the emblem of foresight, because nature protects it with thorny leaves, until it reaches above the bite of cattle, when the leaves shine without a prickle.

Rogers observes, "Difficulties and temptations will more easily be borne---or avoided, if with prudent foresight we arm ourselves against them." 


\section{FORGET ME NOT.}

Mouse-ear Scorpion Grass.-Myosotis Palustris.

"Pour exprimer l'amour, ces fleurs semblent éclore ; Leur langage est un mot-mais il est plein d'appas! Dans la main des amans elles disent encor:

Aimez-moi, ne m'oubliez pas."

Lettres à Sophie.

This plant so celebrated in German lovesong, under the emblem of "Vergils mich nicht," has hence been made to signify "forget me not," by all the sonnet writers of Europe.

"Where time, on sorrow's page of gloom

Has fixed its envious lot,

Or swept the record from the tomb,

It says-Forget-me-not." 


\section{FORSAKEN.}

Lilac.-Syringa.

\section{"The lilac hangs to view}

Its bursting gems in clusters blue."

The eastern nations, from whence this beautiful shrub was originally brought, use the lilac as the emblem of the forsaken, because it is the flower lovers offer their mistresses when they abandon them.

It may generally be observed, that those who forsake their family and friends, soon become anxious to run away from themselves. 


\section{FRANKNESS.}

\section{OSIER.-Salix viminalis.}

"And bending osiers into baskets weaved."

Virgil.

Frankness or openness is represented by these twigs so celebrated for their pliability in forming basket-work.

\section{FRESHNESS, OR BLOOM OF COMPLEXION.}

Damask Rose, or the Rose of Damascus.

"A bed of lilies flower upon her cheek, And in the midst was set a circling rose." $P$. Fletcher.

"She never told her love;

But let concealment, like a worm i' th' bud, Prey on her damask cheek."

This emblem, which is so conformable to nature, is sanctioned by the poets of every age. 


\title{
FRIVOLOUS AMUSEMENT.
}

\author{
Bladder-Senna.-Colutea.
}

The curious, inflated, and bladder-like legumes of this shrub being frequently made the toy of idle moments, have induced the French to name it Baguenaudier. M. Pirolle says, "Fruit dans des vessies rougeâtres qu'on fait claquer par la pression pour baguenauder, d'où son nom."

"Triflers not e'en in trifles can excel; 'Tis solid bodies only polish well."

Young. 


\section{FRUGALITY.}

Endive.-Cichorium endivia.

"A garden-sallad, Of endive, radishes, and succory."

Dryden.

The succory formerly made one of the dishes of frugality.

"Then turn to-night, and freely share

Whate'er my cell bestows;

My rushy couch and frugal fare,

My blessing and repose.

_ from the mountain's grassy side

A guiltless feast I bring;

A scrip, with herbs and fruits supply'd,

And water from the spring."

Goldsmith.

Arbuthnot says, "It is impossible to march up close to the frontiers of frugality, without entering the territories of parsimony." 


\section{GAIETY.}

Butterfly Orchrs.-Habenaria bifolia.

" The orchis race with vary'd beauty charm, And mock the exploring bee or fly's aerial form."

Mrs. Charlotte Smith.

The butterfly, by its airy movements and its showy embellishments, gives naturally an idea of gaiety; and from hence the flower, which is thought to resemble this short-lived insect, has been selected for this emblem.

" Like some fair flow'r that early spring supplies, That gaily blooms, but ev'n in blooming dies."

Pope.

\section{GALLANTRY. - See CRAFTINESS.}




\section{GENEROSITY.}

An Orange-tree, with Fruit and Flowers.

This tree appears to have been chosen to express generosity, from its bearing fruit and flowers at the same time; and therefore, like that noble feeling, continually tending to the communication of benefit.

\section{GENIUS.}

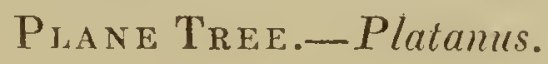

"His spreading planes their pleasant shade extend."

\section{Lauderdale's Virgil.}

This beautiful eastern tree, which the ancients consecrated to the Genii, is made the emblem of Genius because the philosophers of Athens held their discourses under the wide spreading branches of the plane.

"One science only will one genius fit;

So vast is art, so narrow human wit."

Pope. 


\title{
GENTEEL, PRETTY.
}

\author{
Rose.-Pompone.
}

This compact, pretty little offspring of the provins rose, comes about as near to its parent as the term genteel does to elegant, or pretty to beautiful.

"The pretty gentleman is the most complaisant creature in the world, and is always of my mind."

Spectator.

\section{GLORY.}

La UREL.-Prumus Laurocerasus.

"The laurel, meed of mighty conquerors."

Fairy Queen.

To wear a crown of laurel has been the soldier's ambition from the earliest ages to the present day; and when placed on the brow of a hero who has defended his country, its rays are truly glorious.

"Think it no glory to swell in tyranny."

Sidney. 


\section{GOOD EDUCATION.}

Cherries.-Prumus Cerasus.

" Education, power divine."

Roscoe.

This beautiful fruit is made the emblem of good education, because cultivation changes it from a worthless state into a delicious drupe.

\section{GOOD-NATURE.}

Winte Muldein.-Verbaseum Lychnities.

This medicinal plant was formerly in great repute on account of its power to soothe and mitigate pain ; and from hence, we presume, the emblem. 


\section{GOODNESS.}

Mercury, or Good Henry.-Mercurialis.

This plant (says a French author) which grows without culture in the midst of our plains, will confer a more lasting duration on the memory of Henri Quatre, than the statue of bronze placed on the Pont Neuf, though protected by an iron rail and a guard of soldiers.

\section{GOSSIP.}

Сован.—Cobca scandens.

"Go to a gossip's feast, and goude with me." "With all my heart, I'll gossip at this feast."

Shakspeare.

This Mexican plant, whose flowers remind us of the tea-table equipage, and whose tendrils, like the tongue of the gossip, lets nothing escape which it chances to meet with, 
thus runs from branch to branch, or from post to pillar, to exhibit its floral cup and saucer, the symbol of innocent chit-chat, as well as the emblem of venomous scandal. The most dangerous gossips are those who

"Fawn on men, and hug them hard, And after, scandal them."

Shakspeare.

\section{GRACE.}

Hundred-Leaved Rose.-Rosa centifolia.

This is the rose with which painters choose to represent Love and Hymen; but, why it is selected from amongst the roses as the emblem of Grace we know not, since the regularity by which its petals are placed, renders it less graceful than several other roses. 


\section{GRACE, OR PURIFICATION.}

Ru F.-Ruta graveolens.

"Bow, and sue for grace

With suppliant knee."

\section{Milton.}

"Reverend sirs,

For you there's rosemary and rue; these keep

Seeming and savory all the winter long :

Grace and remembrance be to you both."

Shakspeare.

This plant was formerly called Herb of Grace, from its being used to sprinkle holy water.

"Here did she drop a tear; here in this place, I'll set a bank of rue, sour herb of grace." 


\title{
GRANDEUR.
}

\section{Beech Trae.-Fugus.}

\author{
"And the beech \\ Of oily nuts prolific."
}

This noble tree vies even with the oak in stateliness and grandeur; whilst its silvery bark and glossy foliage renders it one of the greatest ornaments to the forest.

The true grandeur of men consists in the greatness of their minds, and the nobleness of their actions. 


\section{GRATITUDE.}

Small White Bell Flower.-Campanula.

"The debt immense of endless gratitude."

Milton.

This little bell flower is made the emblem of Gratitude, in allusion to its simplicity and salutary virtues; or from the name which it bears in France of Religieuse des Champs. 


\section{HATRED.}

\section{Basin.-Ocimum Basilicum.}

"The basil-tuft that waves

Its fragrant blossom over graves."

This emblem is derived from superstitious prejudice which condemned the fragrant Basil as one of the most hurtful of all herbs.

Locke observes, that " hatreds are often begotten from slight and almost innocent occasions ;" and Sherlock says,

"Hatred has in it the guilt of murder." 


\title{
A HEART IGNORANT OF LOVE.
}

\author{
Bud of a WhITE Rose.
}

Mythologists tell us that the rose was origi nally white, and that the warmer tint was first given to it by the blood of Venus.

"While the enamoured queen of joy

Flies to protect her lovely boy,

On whom the jealous war-god rushes;

She treads upon a thorned rose,

And while the wound with crimson flows,

The snowy floweret feels her blood, and blushes."

Catullus. 


\section{HEEDLESSNESS.}

Aluon D.-Amygdalus.

" Like to an almond-tree, mounted high

On top of green Selenis, all alone,

With blossoms brave bedecked daintily;

Whose tender locks do tremble every one,

At every little breath that under heav'n is blown."

Fairy Queen.

The blushing petals which bedeck the leafless branches of these trees that of old embellished the banks of the Jordan, are made emblematical of heedlessness, from their venturing forth before nature has prepared the foliage for their protection.

"Mark well the flow'ring almonds in the wood: If od'rous blossoms the bearing branches load, The glebe will answer to the sylvan reign, Great heats will follow, and large crops of grain."

Dryden. 


\section{HONESTY.}

HonestY.-Lunaria.

"- mine honesty shall be my dower."

This pretty flower owes its valuable name to the nature of its singular seed vessel, that honestly shews its number of seeds.

Lunaria was formerly used for the most dishonest purposes.

"Enchanting lunary here lies, In sorceries excelling."

Drayton. 


\section{HOPE.}

HAwтноRN.-Crategus.

"Now let me sit beneath the whitening thorn."

"And hope, that decks the peasant's bower, Shines like the rainbow through the shower:"

Cunningham.

In floral language the hawthorn blossoms are made the happy emblem of Hope, from the custom of the Athenian girls crowning themselves with these flowers at weddings. The altar of Hymen was also lighted with torches of this tree, which from its gaseous nature, produces a bright flame in its green state.

" Hope, like the glinmering taper's light, Illumes and cheers the way,

And still, as darker grows the night, Enits a brighter ray."

Goldsmith. 


\section{HORROR.}

Creeping Cereus.-Cactus flagelliformis.

"O sight

Of terror, foul and ugly to behold,

Horrid to think, how horrible to feel !'”

Milton.

This plant, so dangerous to the touch, is frequently called the serpent, and from hence the emblem.

Yet Flora has bestowed upon it one of the most beautiful flowers in nature.

\section{HOSPITALITY.}

OА . -Quercus.

" the sturdy oak,

A prince's refuge once."

This noble British tree that feeds our herds, 


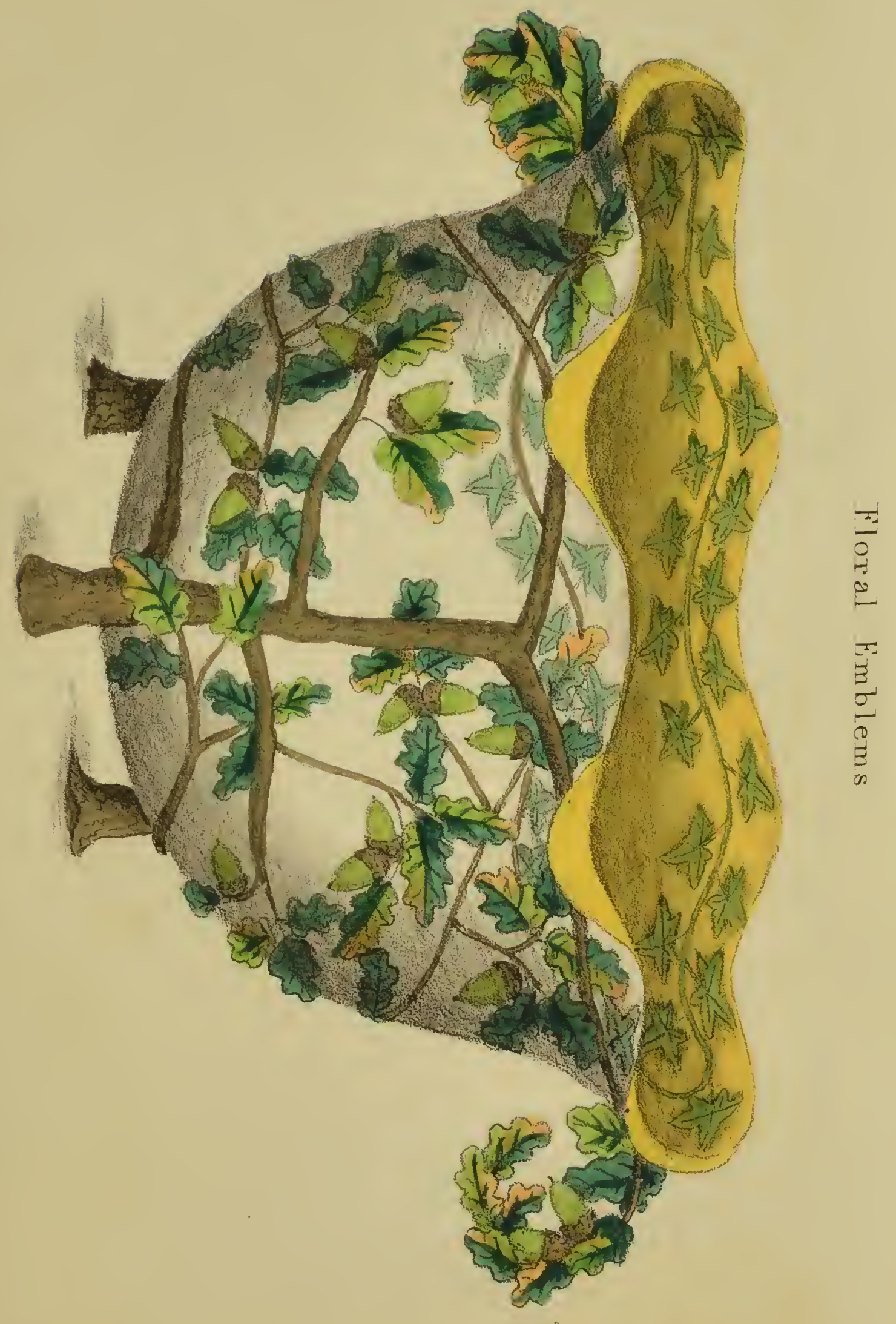



shelters our persons, and protects our commerce,

"Stems the vast main, and bears tremendous war To distant nations, or with sov'reign sway, Awes the divided world to peace and love."

Philips.

" Receive the shipwreck'd on your friendly shore;

With hospitable rites relieve the poor."

Dryden.

\section{HUMANITY.}

Marsi-mallow.-Althea officinalis.

"Alas! when mallows in the garden die."

This plant, so celebrated for relieving the wounds of our ancestors, and decorating their graves, is also made the emblem of a sweet or mild disposition.

" enquire the wretched out, And court the office of soft humanity?" 


\section{HUMILITY.}

\section{Broom.-Spartium.}

"Even humble broom and osiers have their use."

In the hieroglyphical language of flowers, the broom is made the emblem of Humility from the following historical anecdote.

Fulke, earl of Anjou, having been guilty of some crime, was enjoined, by way of penance, to go to the Holy Land and submit to castigation. He acquiesced, habited himself in lowly attire, and as a mark of his humility, wore a sprig of broom in his cap.

The expiation being happily finished. Fulke adopted the name of Plantagenest, from the latin of this shrub, planta-genesta. 
His descendants continued the name, and many successive nobles of the line of Anjou, distinguished themselves by decorating their helmets with this plant.

The arms of Richard the First were, "two lions combattant." Crest, a plantagenista, or broom sprig. Upon his great seal, a broom sprig is placed on each side his throne.-Sandford's Genealogical History.

" the broom,

Yellow and bright as bullion unalloyed,

Her blossoms."

"There are some that use

Humility to serve their pride, and seem

Humble upon their way to be the prouder At their wish'd journey's end.' 


\section{BURN.}

Common Cactus, or Indian Fig.-Cactus Opuntia.

"Tranio, I burn, I pine, I perish, Tranio, If I achieve not this young modest girl."

Shakspeare.

The spines of this singular cactus, are nearly as troublesome to extricate from the skin, as the flames of Cupid are to extinguish in the heart.

\section{DIE, IF I AM NEGLECTED.}

\section{Laurestine,-Viburmus Timus.}

"Rescrie my poor remains from vile neglect."

Prior.

This hardy plant, which embellishes our winter groves with its exotic flowers, will not survive long in neglected grounds; and from thence the emblem which approaches so near to the blighting blast of contempt. 
The Indians have a proverb, which says, the dart of contempt will even pierce through the shell of a tortoise.

This plant is dedicated to St. Faine.

\section{IDLENESS.}

Mesembranthemum, or Fig-marigolid.

Mesembryanthemum.

"Sluggish idleness, the nurse of sin,

Upon a slothful ass he chose to ride."

Fairy Queen.

This numerous genus of succulent plants, were formerly named mesembrianthemum, and noon-flower, because most of the species do not expand their gay petals before midday, and seldom even at that late hour, unless the sun awakes them by his powerful rays: yet it is amongst the earliest flowers that take repose, as the petals are generally closed before the god of day has left the horizon; and we therefore bestow it on the sluggard, for his armorial bearings. 
"For thee, O idleness! the woes

Of life we patiently endure;

Thou art the source whence labour flows,

We shun thee but to make thee sure.

"For who'd sustain war's toil and waste,

Or who th' hoarse thund'ring of the sea ;

But to be idle at the last,

And find a pleasing end in thee?"

Smart.

"The tyrant Lucre no denial takes;

At his command th' unwilling sluggard wakes."

Dryden.

\section{IMMORTALITY.}

\section{Amarantir.-Amarunthus.}

"Immortal Amaranth! a flower which once

In Paradise, fast by the tree of life,

Began to bloom ; but soon for man's offence

To heaven removed, where first it grew; there grows

And flowers aloft, shading the font of life:

And where the river of bliss, through midst of heaven

Rolls o'er Elysian flowers her amber strain,

With these that never fade."

Milton.

Homer having described the Thessalians as wearing crowns of Amaranth flowers at the 
funeral of Achilles, has induced the bards to place it in the list of funereal flowers, and to make it the emblem of immortality.

It is one of the flowers which retain their beauty in a dried state; and hence it is so frequently used in the ceremonies of the Romish church, and to decorate the monuments of the cemetery of Pere la Chaise, the romantic "Grave of France."

\section{IMPATIENCE.}

BALSA.r.-Impatiens Balsamina.

"Balsam, with its shaft of amber."

This emblem is given on account of the elasticity of the capsule when ripe, which darts out its seed the moment it is touched. The generic name is derived on the same account. 
The Turks represent ardent love by this Hower.

" Fame, impatient of extremes, decays Not more by envy than excess of praise."

Pope.

\section{IMPERFECTION.}

\section{HENBANE.-Hyoscyamus.}

" That to which old Socrates was curs'd;

Or henbane juice, to swell 'em till they burst."

Dryden.

This plant, more dangerous by its deleterious qualities, than perfect in its medicinal properties, affects the brain with the most fantastic delirium and delusions. 


\section{IMPORTUNITY OR INTRUSION.}

Common Thistle.-Carducis.

"Now where the thistle blows his feather'd seed, Which frolick zephyrs buffet in the air."

Falconer.

"Wide o'er the thistly lawn as swells the breeze, A whitening shower of vegetable down Amusive floats."

Thompson.

This plant, that furnishes its seeds with wings by which it flies from hill to dale, too frequently intrudes itself into our fields, to the injury of the farmer's best hopes.

"'Tough thistles choak'd the fields, and kill'd the corn, And an unthrifty crop of weeds was born."

Dryden.

The thistle is symbolical of Scotland, it being the emblematical flower of the unfortunate Stuarts, who so frequently wore the Cluas-an$\mathrm{N} 2$ 
fheiah (melancholy thistle) in their crown. It is now so happily blended with the English rose, that we hope no hand will escape the prickles of each, who shall dare attempt to divide them.

\section{INCONSTANCY.}

Great-flowered Evening Primrose.

Enothera grandiflora.

"Yor evening primroses, when day has fled, Open your pallid flowers, by dews and moonlight fed."

Barton.

This flower, that shuns the day as if it could not face the truth, is made the emblem of inconstancy.

"They know how fickle common lovers are;

Their oaths and vows are cautiously believ'd;

For few there are but have been once deceiv'd."

Dryden. 


\section{INCORRUPTIBLE.}

Cedar of Lebanon.-Pinus Cedrus.

"Once were they in their splendour and their pride, As an imperial cedar, on the brow Of the great Lebanon! It rose, arrayed In its rich pomp of foliage, and of wide Majestic branches, leaving far below All children of the forest. To its shade The waters tribute paid, Fostering its beauty. Birds found shelter there, Whose flight is of the loftiest, through the sky; And the wild mountain-creatures made their lair Beneath; and nations by its canopy Were shadowed o'er. Supreme it stood, and ne'er Had earth beheld a tree so excellently fair."

From the Spanish.

The ancients considered the timber of this tree to be not only incorruptible, but that whatever it inclosed, became imperishable. They therefore deposited their precious manuscripts in chests made of this tree, which gave 
rise to a proverb; to praise a work, it was said, " It is worthy of being cased in cedar." The ancients also drew a juice from the cedar, with which they smeared their writings to preserve them from decay, and which is alluded to by Horace; by means of which it is said, that Numa's books were so wonderfully preserved. The Egyptians used this extract of the cedar with other drugs, to embalm their dead bodies, believing it would make them incorruptible; and a 3000 years experiment has proved them tolerably correct: hence the emblem. It was customary with the Jews to plant a cedar at the birth of a son, which was cut to form his nuptial bed; and on this account, the Israelites considered it symbolical of constancy and purity. Were the works of men imperishable, the globe would be covered with monuments of folly. 


\section{INDEPENDENCE.}

Plum-tree.-Prumus domestica.

"The mealy plum

Hangs purpling, or displays an amber hue."

Several kinds of plums grow without the aid of cultivation, and the tree has therefore been made the emblem of independence.

" Give me, I cry'd, enough for me, My bread and independency."

$$
\text { Pope. }
$$

There is a kind of plum in the city, oftener coveted than enjoyed.

"The miser must make up his plum, And dares not touch the hoarded sum."

Prior. 


\section{INDIFFERENCE.}

Ever-flowering CANDY-TUFt.-Iberis semperflorens.

In the floral language of Persia, this plant is made the emblem of indifference, because it blossoms alike through the heat of the summer months, and the severity of the winter's frost, equally disregarding the rays of Sol, and the breath of Boreas.

" Indiff'rence, clad in wisdom's guise, All fortitude of mind supplies; For, how can stony bowels melt In those who never pity felt?" 


\section{INDUSTRY.}

BEE ORCHIs.-Ophrys apifera.

"Perhaps, his fragrant load may bind

His limbs; we'll set the captive free;

I sought the living bee to find, And found the picture of a bee."

Langhorne.

This singular flower is made the emblem of industry, from its resemblance to the insect that has ever been held the symbol of this virtuous habit.

"So works the honey bees, Creatures, that by a ruling nature taught The art of order to a peopled kingdom." Shakspeare. 


\title{
INFIDELITY.
}

\author{
Yellow Rose.-Rosalutea.
}

The colour of this flower, so terrible to lovers, is the highest mark of distinction in Eastern countries.

\section{INGENUOUS SIMPLICITY.}

Mouse-ear Chickweed.-Cerastum.

Ingenuous simplicity is represented by these little white flowers, which are more frequently found in neglected banks than in cultivated grounds.

"Of manners gentle, of affections mild, In wit a man, simplicity a child."

Pope. 


\section{INGRATITUDE.}

Yellow Gentian.-Gentiana lutea.

The strictest care and the greatest art of the florist is seldom sufficient to make this plant thrive in the parterre ; on which account the emblem has been devised.

" Ingratitude! thou marble-hearted fiend, More hideous, when thou show'st thce in a child, Than the sea monster."-King Lear.

Crow foot.-Wild Ranunculus.

"And the crow-flowers, golden-hued."

"Ingratitude's a weed of every clime,

It thrives too fast at first, but fades in time."

Garth.

This emblem of ingratitude insinuates itself into pastures, and destroys the flocks by its secret poison.

"Ce joli bouton satiné,

Qui sourit comme l'imnocence,

Recèle un suc enipoisonné

Et souvent blesse l'imprudence." 


\section{INJUSTICE.}

Hop.-Humulus.

" Lo, on auxiliary poles, the hops Ascending spiral, ranged in meet array."

Philips.

Injustice suffered this plant to be regarded as a noxious weed, until we began to

"Brew in October, and hop it for long keeping."

\section{INNOCENCE.}

DAISY.-Bellis perennis.

"With silver crest and golden eye."

This "bonny gem" of Scotland's sweet poet, is made the emblem of innocence, from its forming one of the earliest floral amusements of infancy. 
Floral Emblems

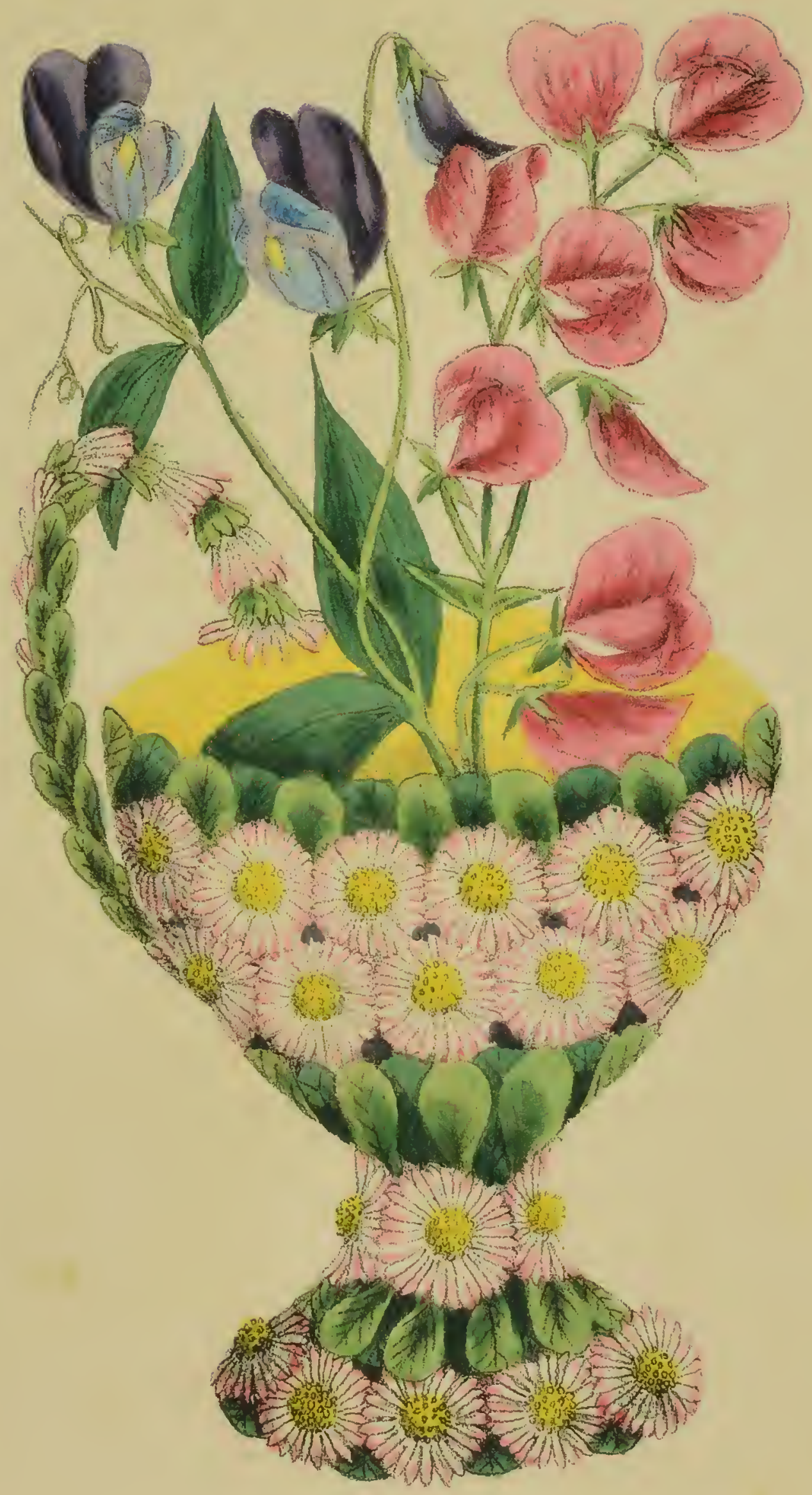

Delicate \& Tasting Pleastres arreing from the Cuxp of Innocone 

"The glowing gem, the sparkling stone,

May strike the sight with quick surprise

But truth and innocence alone,

Can still engage the good and wise."

Fordyce.

The white violet is also an emblem of

"Simplicity, and spotless innocence."

The common daisy is dedicated to St. Margaret of Cortona.

\section{INSPIRATION.}

Angerica.-Angelica.

"My fancy form'd thee of angelic kind."

Pope.

Parkinson says, this plant was named Angelica from "the angel-like properties therein." Since men have began to act more on the principles of reason than on pretended inspiration, this plant has become less celebrated. 
The ancients considered this plant possessed of angelic virtues; and from whence it derived its exalted title. Amongst other properties, it was supposed to possess that of defending persons from enchantment and the evils of witchcraft, which induced the poets to make it emblematical of inspiration.

"Augurs and soothsayers, astrologers, Diviners, and interpreters of dreams, I ne'er consult, and heartily despise."

\section{INSTABILITY.}

\section{Dahlia.-Dahlia.}

The first introduction of this Mexican flower marked the year when France became revolutionised; these plants were lost, until again introduced in the year that saw Napoleon made Emperor of the French nation, on which account it has been made the emblem of instability. 
Addison remarks, that " instability of temper ought to be checked, when it disposes men to wander from one scheme of government to another; such a fickleness cannot but be fatal to any country."-Freeholder.

\section{INTOXICATED WITH PLEASURE.}

Peruvian Heliotrope.-Heliotropium peruvianum.

"Qui voit ta fleur en boira le poison :

Elle a donné des sens à la sagesses, Et des désirs à la froide raison."

Bernis.

Jessieu says, he was intoxicated with delight when first he discovered this fragrant flower on the mountains of the Cordilleras. When first introduced to France, no vase was thought too expensive or precious for the growth of this odorous plant. 
A lady being asked one day what induced her to be so passionately fond of a flower that presented so little lustre to the eye, replied, "Que la parfum de l'heliotrope est à mon parterre ce que l'ame est à la beauté, la volupté à l'amour, et l'amour à la jeunesse."

"As with new wine intoxicated both, They swim in mirth, and fancy that they feel Divinity within them breeding wings, Wherewith to scorn the earth." Milton. 


\section{JEALOUSY.}

French Marygold.-Tagetes Patula.

"Dans le souci, je reconnais

L'époux d'une femme infidèle."

"And winking marybuds begin

To ope their golden eyes."

Shakspeare.

On account of its colour, this flower is given as an emblem of those who are said to wear yellow stockings.

\section{JEST, OR BANTERING.}

Southern-wood.-Artemisia Abrotamum.

"That with the yellow crown, named from the queen, Who built the mausoleum?"

\section{Smith.}

This plant (frequently called Old Man), so much esteemed by the good people of White- 
chapel, and so little regarded by the rest of the world, is made the emblem of jesting and bantering.

L'Estrange says, "It is no new thing for innocent simplicity to be the subject of bantering drolls.

\section{JUSTICE.}

Rudвескі.-Rudbeckia.

This American plant received its title in honour of Olans Rudbeck, whose botanical labours have been thus justly acknowledged by his successors. 


\section{KNIGHT ERRANTRY.}

Monk's-hood, or Helmet-flower.

Aconitum Napellus.

"L'Aconit, au suc malfaisant,

Comme s'il s'armait pour la guerre, Eléve un casque ménaçant."

We present this flower as the emblem of knight-errantry, because it rears its threatening helmet as if to protect the gayer favourites of Flora.

"The ancient errant knights

Won all their mistresses in fights:

They cut whole giants into fritters,

To put them into am'rous twitters."

Hudibras. 


\section{LAMENTA'TION.}

\section{Aspen Tree.-Populus tremula.}

"Why tremble so, broad aspen tree?

Why shake thy leaves, ne'er ceasing?

At rest thou never seem'st to be,

For when the air is still and clear, Or when the nipping gale increasing,

Shakes from thy boughs soft twilight's tear, Thou tremblest still, broad aspen tree, And never tranquil seem'st to be."

Bigoted ignorance states that the cross was made from this tree, since which time the leaves have never known rest, and from hence the emblem seems to have originated.

"The night has been unruly where we lay;

And chimneys were blown down : and, as they say, Lamentings heard i' th' air, strange screams of death."

Shakspeare. 


\section{LASTING BEAUTY.}

Stock, or Giliyflower.-Mathiola.

"Fair is the gillyflow'r of gardens sweet."

Gay.

"And lavish stock, that scents the garden round."

Thompson.

Lasting beauty is represented by this flower whose charms, although less graceful than the rose or the lily, are more durable, and consequently embellishes the parterre for a greater length of time.

"Herbs and flowers, the beauteous birth

Of the genial womb of earth, Suffer but a transient death, From the winter's cruel breath!

Zephyr speaks-serener skies, Warm the glebe, and they arise! We, alas! earth's haughty kings, We that promise mighty things, 
Losing soon life's happy prime,

Droop and fade in little time, Spring returns, but not our bloom, Still 'tis winter in the tomb!"

Cowper.

\section{LASTING PLEASURE.}

Everlasting Pea.-Lathyrus Latifolius.

This perennial plant, that

"Catch the neighbouring shrub

With clasping tendrils, and invest his branch, Else unadorned, with many a gay festoon."

is made the emblem of lasting pleasure, since its beautiful clusters of flowers are renewed every year to the joy of all the admirers of Flora's gifts. 


\section{LIFE.}

Lucerne.-Medicago Sativa.

"Te quoque Medica putres,

Accipiunt sulci."

Virgil.

This plant, so valuable to the agriculturalist, is made the symbol of life, since it not only flourishes in poor soil, but is so tenacious of existence, that it assumes a vigorous and vernal appearance in a few weeks after it has felt the effects of the scythe.

"When I consider life, 'tis all a cheat,

Yet fool'd by hope men favour the deceit, Live on, and think to-morrow will repay;

To-morrow's falser than the former day;

Lies more; and when it says we shall be blest

With some new joy, takes off what we possess.

Strange cozenage! none would live past years again,

Yet all hope pleasure in what yet remain ;

And from the dregs of life think to receive

What the first sprightly running could not give;

I'm tir'd of waiting for this chemick gold,

Which fools us young, and beggars us when old." 


\section{LIGHTNESS, LEVITY, FICKLENESS.}

LARKSPUR.-Delphinium Ajacis.

The graceful airiness of this elegant flower, which varies so much both in shape and colour, is made emblematical as above. The single blue flower, distinguishing lightness, the double flower, levity, and the party coloured, fickleness.

\section{Of levity, Pope says,}

"Where wigs with wigs, with sword-knots sword-knots strive,

Beaus banish beaus, and coaches coaches drive, This erring mortals levity may call."

Spencer thus cautions us in the Fairy Queen.

"Beware of fraud, beware of fickleness, In choice and change of thy dear-loved dame." 


\section{LIVELY AND PURE LOVE.}

RED PINK.-Dianthus.

"Bring hether the pincke and purple cullambine, With gelliflowres;

Bring coronations. and sops in wine, Worn of paramours."

Spencer.

This fragrant beauty is deserving the high rank it holds in floral emblems.

" Happy they! the happiest of their kind ! Whom gentler stars unite, and in one fate

Their hearts, their fortunes, and their beings blend."

Thompson. 


\section{LOVE.}

Myrthe.-Myrtus.

"The lover's myrtle."

Thompson.

" Like a myrtle tree in flower Taken from an Asian bower, Where with many a dewy cup, Nymphs in play had nursed it up."

Hunt's Catullus.

"The lover with the myrtle sprays, Adorns his crisped tresses."

Drayton.

Mythological writers state that when Venus first sprang from the bosom of the waves, the Hours preceded her with a garland of myrtle, since which it has been dedicated to the goddess of beauty, and made the emblem of love.

" Imperial passion! sacred fire!

When we of meaner subjects sing,

Thou tun'st our harp, thou dost our souls inspire;

"Tis love directs the quill, 'tis love strikes every string." 
"Love : that vast passion of the mind,

Whose roving flames does traverse o'er

All nature's good, and search for more;

Still to thy magic spheres confin'd.

'Tis beauty's all we can desire ;

Beauty the native mansion of love's fire."

\section{A LOVE MATCH.}

LONDON-PRIDE, OR NONE-SO-PRETTY.

Saxifraga Umbrosa.

"If this," he cries, " a bondage be, Who would wish for liberty !"

This pretty little flower, which the French call amourette, is made the emblem of those love affairs which generally meet with the most opposition.

"The father, too, a sordid man,

Who love nor pity knew,

Was all unfeeling as the clod,

From whence his riches grew.

Mallet. 


\section{LUSTRE.}

Aconite-leaved Crowfoot, or Fair Maids of France.-Ramenculus Aconitifolius.

This pretty alpine plant, whose white petals shine so agreeably in the parterre, is made the symbol of lustre.

"To the soul time doth perfection give, And adds fresh lustre to her beauty still."

Davies.

But not so to the person,

"Pass but some fleeting years, and these poor eyes, Where now without a boast some lustre lies, No longer shall their little honours keep, But only be of use to read or weep."

Prior. 


\section{LUXURIANCY.}

Horse-chesn ut.-ZEsculus Hippocastanum.

" Filled with flowers-flowers that seem Lighted up by the sunbeam; and leaves

Green as hope before it grieves." L.E. L.

From the luxuriant growth of this Asiatic tree in European soil has originated the emblem.

"Prune the luxuriant, the uncouth refine, But.show no mercy to an empty line."

Pope. 


\section{MAJESTY AND POWER.}

Crown Imperial.- Fritillaria imperialis.

"The crown imperial; lilies of all kinds, The fleur-de-luce being one! O, these I lack, To make you garlands of."

Shakspeare.

This Persian flower, that towers above the more humble plants of the parterre, holds a high rank in floral emblems.

"The lily's height bespake command,

A fair imperial flower;

She seemed designed for Flora's hand,

The sceptre of her power." 


\section{MATERNAL LOVE.}

Mossy Saxifrage, or Ladies Cushion.

Saxifraga hypnoides.

"The babe had all that infant care beguiles, And early knew his mother in her smiles : At his first aptness the maternal love, Those rudiments of reason did improve."

Dryden.

This plant, that so frequently clothes the naked rocks of Chedder, Snowdon, and Ben Lomond, is made symbolical of this instinctive love.

"Within her breast though calm, her breast though pure, Motherly cares and fears got head, and rais'd

Some troubled thoughts."

Milton. 


\section{MELANCHOLY.}

"Thou flickering: solitary leaf, That hang'st on yonder blighted tree, Sad emblem of deserted grief, How like thou art to me."

Faded leaves are made emblematical of this gloomy and pensive temper.

"Cold grew the foggy morn, the day was brief, Loose on the cherry hung the crimson leaf."

Crabbe.

"So melancholy never tints

The mind that owns her care

With health or warmth, but only prints

Her own cold image there."

Neele.

How much better then to

"Think of all our miseries

But as some melancholy dream, which has awaked us To the renewing of our joys." 


\title{
MEDICINE.
}

\author{
Swallow-wort,-Asclepias. \\ "Well knew he the old Esculapius."
}

Chaucer.

Tradition asserts that the virtues of this plant were discovered by the god of medicine, from which cause the generic name was given, and the emblem devised.

\section{Dryden says,}

"He 'scapes the best, who nature to repair,

Draws physic from the fields in draughts of vital air." 


\title{
MELANCHOLY OR FORSAKEN LOVER.
}

\author{
Weaping WiLlow.-Salix babylonica.
}

“ Thus o'er our streams do eastern willows lean In pensive guise; whose grief-inspiring shade, Love has to melancholy sacred made."

Delille.

Few emblems have been more celebrated by the poets than this of the forsaken lovers.

"To the brook and the willow that heard him complain, Ah, willow! willow!

Poor Colin went weeping and told them his pain." Rowe.

"I offered him my company to a willow tree, to make him a garland, as being forsaken; to bind him up a rod, as being worthy to be whipt."-Shakspeare.

- In love the sad forsaken wight The willow garland weareth."

Drayton. 


\section{MEMORY.}

Syringa, or Mock Orange.-Philadelphus.

"The sweet syringa yielding but in scent

To the rich orange."

Mason.

This fragrant flower is made the emblem of memory, because when once we inhale its penetrating odour, it continues to dwell on the sense for a considerable time.

"Hail, memory hail! in thy exhaustless mine, From age to age unnumbered treasures shine! Thought and her shadowy brood thy call obey, And place and time are subjects to thy sway! Thy pleasures most we feel when most alone, The only pleasure we can call our own."

Rogers. 


\title{
MESSAGE, OR MESSENGER.
}

\author{
IrIS._.Iris.
}

"The various iris, Juno sends with haste."

"L' iris que flore a prise aux cieux."

This flower, which the poets have chosen as the emblem of the messenger of the gods, takes its name from the celestial bow, on account of its various colours.

"Nor iris, with her glorious rainbow clothed So fulgent, as the cheerful gardens shine With their bright offspring." 


\section{MIRTH, OR LAUGHTER.}

Safiron Crocus.

Is represented in floral language by a saffron crocus with its petals turned down so as to show the whole of the stamina.

An old proverb, alluding to one of a merry temper says,

"Dormivit in sacco croci."

"He hath slept in a bag of saffron."

This exhilarating medicinal plant, when taken in large quantities, causes immoderate mirth and involuntary laughter, even to a dangerous degree.

"With genial joy to warm the soul, Bright Helen mix'd a mirth inspiring bowl."

Pope. 


\section{MISANTHROPY.}

Fullers Teasel.—Dipsacus fullomum.

"I am misanthropos, and hate mankind."

Shakspeare.

These unhappy dispositions are represented in floral emblems by the prickly head of the dipsacus, a plant so disagreeable to animals in general, that even the ass refuses it. The conical receptacle of this plant becomes the harbour of earwigs, as the head of a misanthrope becomes the receptacle of terrible antipathies.

The singularly rough heads of the teasel are useful in raising the nap upon woollen cloths, but the head of a misanthrope is as useless as an ear of blighted corn.

"His only scope

Was to be held a misanthrope ;

This into gen'ral odium drew him."

Swift. 


\section{MODESTY.}

SWEET Violet.-Viola odorala.

"Franche d'ambition, je me cache sous l'herbe, Modeste en ma couleur, modeste en mon séjour; Mais si sur votre front je puis me voir un jour, La plus humble des fleurs sera la plus superbe."

Desmartes.

This unobtrusive flower is no less honoured by its emblem than the rose or the myrtle, to which it is so essential to complete the delights they can inspire. Its motto is " $\mathrm{Il}$ faut me chercher." Cunningham makes the violet say,

"Modest though the maids declare me, May, in her fantastic train, When Pastora deigns to wear me, Has no flow'ret half so vain."

The poets of the sixteenth century appear 
to have made this favourite flower an emblem of faithfulness.

"Violet is for faithfulness,

Which in me shall abide :

Hoping likewise that from your heart

You will not let it slide."

The sweet violet is dedicated to St. Gertrude.

\section{MOMENTARY HAPPINESS.}

Virginian SPIDER-WORT._-Tradescantia virginica.

"Momentary as sound,

Swift as a shadow, short as any dream."

Shakspeare.

This emblem is formed in allusion to the fragility of the flowers of this species of spider-wort, which wither almost as soon as they are perfectly formed. Young says,

"While I a moment name, a moment's past;

I'm nearer death in this verse than the last;

What then is to be done! Be wise with speed;

A fool at forty is a fool indeed." 


\section{MUSIC.}

A BUNdLe of REeds With their panicles, ol? A BRANCH OF PINE TREE WITH CONES.

"O music! sphere-descended maid, Friend of pleasure, wisdom's aid, 'Tis said, and I believe the tale, Thy humblest reed could more prevail, Had more of strength, diviner rage, Than all which charms this laggard age."

Collins.

This emblem is derived from the mythology of the early poets, as we cannot admit the accustomary symbols of lyre and harp in this floral collection.

"By music minds an equal temper know, Nor swell too high, nor sink too low; Warriors she fires with animated sounds, Pours balm into the bleeding lover's wounds." Pope. 


\title{
MY BEST DAYS ARE PAST.
}

\author{
Colchicum, or Meadow-saffron. \\ Colchicum Autumnale.
}

“ Or temper'd every baleful juice

Which poisonous colchian glebes produce."

In floral language this autumnal flower expresses "my best days are past," for, far from inspiring us, like the crocus, with joy and hope, it appears to announce to all nature the loss of the fine days, and the approach of a cheerless atmosphere.

" Catch, then, O ! catch the transient hour, Improve each moment as it flies :

Life's a short summer, man a flower, He dies-alas! how soon he dies!"

Johnson. 


\title{
MY REGRETS WILL FOLLOW YOU TO THE GRAVE.
}

\author{
AsPноDEL._Asphodelus.
}

" L'Asphodèle aux mutes tombeaux Arrache les livides ombres Et du Lêthé borde les eaux."

The root of the asphodel not only furnished our ancestors with food whilst living, but was planted on their graves, with a belief that it would supply the manes of the dead with nourishment.

"By those happy souls, who dwell In yellow meads of asphodel."

" Au-dehors je suis entouré de mauve et d' asphodèle, et au-dedans je ne suis qu'un cadarre."-Ancient Tombs.

"Dull grave-thou spoil'st the dance of youthful blood, Strik'st out the dimple from the cheek of mirth, And ev'ry smirking feature from the face;

Branding our laughter with the name of madness."

Blair. 


\section{NEATNESS.}

Genista.-Genista florida.

This plant appears to have been made the emblem of neatness from its frequent use in forming besoms.

"I am sent with broom before, To sweep the dust behind the door."

\section{NEGLECTED BEAUTY.}

Throat-wort.-Trachelium.

"Rescue my poor remains from vile neglect, With virgin honours let my herse be deck'd And decent emblem."

Prior.

This beautiful flower, being so entirely overlooked by the poet, the painter, and the generality of florists, has induced us to offer it as the above emblem. 


\title{
NEVER-CEASING REMEMBRANCE.
}

\author{
Everlasting, or Cud-Wend.-Gnaphalium.
}

"Each lonely scene shall thee restore,

For thee the tear be duly shed;

Belov'd, till life can charm no more, And mourn'd, till pity's self be dead."

We have devised this emblem for the everlasting flower, both from its name and its frequent use on the continent, in decorating the monuments and graves of departed friends.

"To fair Fidele's grassy tomb,

Soft maids and village hinds shall bring, Each opening sweet of earliest bloom, And rifle all the breathing spring."

Collins. 


\section{NIGHT.}

Convolvulus Minor.-Convolvulus Tricolor.

"Now sunk the sun; the closing hour of day Came onward, mantled o'er with sober gray; Nature in silence, bid the world repose."

Parnell.

The hours of darkness are represented by this belle-de-jour, which closes its sparkling eyes at the close of day, as if to sleep through the dewy night, when

"All things are hush'd, as nature's self lay dead."

"I love thee, mournful, sober night! * * * * * I still enjoy thee-cheerless as thou art; For in thy quiet gloom the exhausted heart Is calm, tho' wretched; hopeless, yct resign'd."

Charlotte Smith. 


\section{OBSTACLE.}

Ox-Eye.-Buphthalurum.

Obstacles sharpen wishes; and it may generally be observed, that where reasoning cannot succeed, they have no other effect than that of forwarding what they were intended to protract.

\section{OBSTINACY.}

Small Bindweed.-Convolvulus Arvensis.

"Convolvulus in streaked vases flush."

Keats.

"No ass so meek, no ass so obstinate."

Pope.

This humble plant is a most formidable enemy to the husbandman, it being difficult to dispossess it of the land it has once taken 
possession of. Lucot says, it represents an obstinate person, who persists in his own opinion, and prefers being torn in a thousand pieces, sooner than to yield benevolently to what is required of him.

"The man resolv'd, and steady to his trust, Inflexible to ill, and obstinately just,

Can the rude rabble's influence despise."

Addison.

\section{OLD AGE.}

Tree of Life.-Arbor-vita, Thuja.

"The Thuja from China's fruitful lands."

The name of Arbor-vitæ justifies this emblem. Young observes,

"Tis greatly wise to know, before we're told, The melancholy news that we grow old." 


\section{ORACLE.}

DANDELION.-Leontodon.

"

Dandelion this,

A college youth, that flashes for a day All gold; anon he doffs his gaudy suit, Touch'd by the magic hand of some grave bishop, And all at once, by commutation strange, Becomes a reverend divine."

\section{Hurdis.}

The medicinal properties of this plant have caused it to be familiarly known by a name that has brought it into contempt, and on which account it is presumed the emblem originated.

"Why, by the verities on thee made good, May they not be my oracles."

Shakspeare. 


\section{ORNAMENT.}

Hornbeam Tren.-Carpimus.

"Ornament,

When foreign or fantastic, never charm'd My judgment."

Mason.

The French have made this tree the symbol for ornament, because it forms most of the cabinets and ornamental divisions of their royal gardens. 


\title{
OBSTACLES, TO OVERCOME, OR
} SURMOUNT.

\author{
Misseltof.-Viscum.
}

"The naturalists are puzzled to explain How trees did first this stranger entertain; Whether the busy birds ingraft it there, Or, else, some deity's mysterious care, As Druids thought; for when the blasted oak By lightning falls, this plant escapes the stroke."

Gurth.

This plant, which is without an earthly inheritance, makes no difficulty in attaching itself to the branches of lofty trees, and there, without apparent labour, subsists upon the ascending sap of its supporter.

When drawn suspended on a tree, it is the symbol of a flattering hanger-on. 


\section{PAINTING.}

Auricula.-Primula Auricula.

"Auricula, enrich'd

With shining meal o'er all their velvet leaves."

Thompsort.

As all the most beautiful flowers that were known to the ancients, had been placed in the hieroglyphical language of plants, we had some difficulty in making a selection worthy of representing the delightful art of painting, for such it must ever be regarded.

"Whether their hand strike out some free design, Where life awakes, and dawns at every line, Or blend in beauteous tints the colour'd mass, And from the canvass call the mimic face."

Pope.

We were unwilling to place any but a European flower on the limner's escutcheon, and have therefore gathered "The queen of the snowy Alps," for their emblem ; for since 
this flower has been fostered by man, nature has allowed art to enrich its hues, and diversify its varieties, almost without end. Painting is a dialect that speaks intelligibly alike to all the globe.

"Their pow'rful language to no realm

Or region is confin'd;

'Tis nature's voice, and understood

Alike by all mankind."

Psalm xix. 3. New Vers.

\section{PARTICIPATION, OR, I PARTAKE YOUR SENTIMENTS.}

\section{Double Daisy.-Bellis hortus.}

The cultivated daisy is made the emblem of participation, because its multiplied petals all partake of one receptacle. Hooker observes, that "Civil society doth more content the nature of man, than any private kind of solitary living; because in society, this good of mutual participation is so much larger." 


\section{PATERNAL ERROR.}

\section{Cardanine. Cuckoo-flower, or Lady's Shock. Nasturtium Pratensis.}

"When daisies pied, and violets blue, And lady's smocks all silver white, And cuckoo-buds of yellow hue,

Do paint the meadows with delight."

Shakspeare.

This flower being one which formed the crown of King Lear, after he had disposed of his regal diadem to his children, has caused the emblem.

" He was met even now

As mad as the vex'd sea : singing aloud;

Crown'd with rank fumiter, and furrow weeds, With harlocks, hemlock, nettles, cuckoo-flowers, Darnel, and all the idle weeds that grow In our sustaining corn."

Shakspeare. 


\section{PATIENCE.}

Patience Dock.-Rumex patientia.

"Aux malheurex, la patience."

Malouvre.

"Have patience."

This emblem is derived from the specific name of the plant, which is also frequently called monk's rhubarb, it being often used by them of old both as a pot-herb and a medicinal plant. Mortimer says,

"Patience, an herb, makes a good boiled salad." 


\section{PEACE.}

Olive.-Olea.

"But he her fears to cease,

Sent down the meek-ey'd Peace;

She, crown'd with olive green, came softly sliding

Down through the turning sphere,

His ready harbinger;

With turtle wing, the amorous clouds dividing,

And waving wide her myrtle wand,

She strikes an universal peace through sea and land."

From the time of the general deluge to the present day, the olive branch has ever been the emblem of peace.

"Come, peace of mind, delightful guest!

Return, and make thy downy nest

Once more in this sad heart :

Nor riches I, nor pow'r pursue,

Nor hold forbidden joys in view;

We therefore need not part."

Cowper. 


\section{PENSIVENESS.}

Cowsurp.-Primula veris.

"__ Cowslips wan that hang the pensive head."

ilton.

"Anxious cares the pensive nymph opprest, And secret passions labour'd in her breast."

Pope.

We offer this, the poets' favourite meadow flower, as symbolical of a mind so nearly allied to melancholy love, that we may occasionally place it on the lover's escutcheon, with this motto from Hurdis :

"The love-sick cowslip, that head inclines, To hide a bleeding heart." 


\title{
PERFECT GOODNESS.
}

\author{
STRA B BER Y . Fragaria.
}

" Content with food which nature freely bred, On wildings and strawberries they fed."

Dryden.

This agreeable and wholesome fruit is made the symbol of perfect goodness, from its fragrance, flavour, and inoffensive qualities Shakspeare says,

"The strawberry grows underneath the nettle; And wholesome berries thrive and ripen best, Neighbour'd by fruit of baser quality." 


\section{PERFIDY.}

The common Laurel in Flower.

Prunus Laurocerasus.

"I treated, trusted you, and thought you mine; When, in requital of my best endeavours, You treacherously practiced to undo me."

Otway.

This beautiful plant carries the most inveterate poison in its veins, hence the emblem; since perfidy is too frequently disguised by the alluring mask of friendship.

"O spirit accurs'd,

Forsaken of all good, I see thy fall

Determin'd, and thy hapless crew involv'd In this perfidious fraud."

Milton. 


\section{PERSECUTION.}

Chequered Fritillary.-Fritillaria Meleagris.

Persecution is represented by this flower, whose chequered petals are too frequently emblematical of the events of life.

"Our necks are under persecution; we labour, and have no rest."

Lamentations, v. 5.

\section{PERSEVERANCE.}

CaNARY-GLass.-Phalaris canariensis.

"Perseverance keeps honour bright;

To have done, is to hang quite out of fashion, Like rusty mail in monumental mockery."

Shakspeare.

We cannot account for this emblem, and perseverance is not to be recommended in all 
cases, since to persevere in any evil course must lead to misery as certainly, as we may overcome difficulties by patient perseverance.

\section{PERSUASION.}

\section{Althe Frutex.-Hibiscus syriacus.}

Beauty will frequently gain over what all the arts of fine persuasion has failed to accomplish. 


\title{
PLAY, OR GAMES.
}

\author{
HYACINTH.-Hyacinthus.
}

"I will play no more; my mind's not on't.

- I I did never win of you;

Nor shall not when my fancy's on my play."

Shakspeare.

The hyacinth, so celebrated by the poets from the time of Homer to the present day, is made the emblem of play, or games, in allusion to the fable which tells us, that this flower sprang from the blood of young Hyacinthus, the favourite of Apollo.

" A well-pois'd disk first liasty Phœbus threw, It cleft the air, and whistled as it flew; It reach'd the mark, a most surprising length, Which spoke an equal share of art and strength. Scarce was it fall'n, when, with too eager hand, Young Hyacinth ran to snatch it from the sand; But the curst orb, which met a stony soil, Flew in his face with violent recoil."

Ovid. 


\title{
PLEASURES OF MEMORY.
}

\author{
PeriwinkLE.-Vinca.
}

"Come Memory, and with me go!

Each lovely flower that breathes the spring Affection's gentle hand shall strew."

Dodd.

The admirers of Rousseau held this flower as the symbol of the pleasures of memory, because its appearance recalled the poet's mind back to former friendships.

"Companions of the youthful scene, Endear'd from earliest days !

With whom I sported on the green, Or rov'd the woodland maze!"

Logan.

Too many of us naturally exclaim in the words of Goldsmith,

" Oh Memory, thou fond deceiver,

Still importunate and vain;

To former joys recurring ever,

And turning all the past to pain." 


\title{
POETRY.
}

\author{
Swetit Briar, or Eglantine. \\ Rosa rubiginosa, or Eglanteria.
}

"Real indigenous poetry is a sweet flower."

Campbell.

"Come, gentle air! and while the thickets bloom, Convey the jasmin's breath divine;

Convey the woodbine's rich perfume, Nor spare the sweet-leaved eglantine."

Shenstone.

The fragrance of the eglantine is as delightful to the olfactory nerves, as the charms of poetry are to the ear; they both reach the soul of sensibility, and each has its thorn.

"How far have we

Prophan'd thy heav'nly gift of poesy?

Made prostitute and profligate the Muse, Whose harmony was first ordain'd above For tongues of angels."

Dryden. 


\section{POPULAR FAVOUR.}

Cistus, or Rock Rose.-Cistus.

"Admire we then,

Or popularity, or stars, or strings,

The mob's applause, or the gifts of kings?"

In floral language, this transient flower is made the emblem of popular favour, since the duration of the one cannot be relied on more than the continuation of the other. Dryden says, "A popular man is, in truth, no better than a prostitute to common fame and to the people." 


\section{POVER'TY.}

Evergreen Clematis.-Clematis cirrhosa.

$$
\text { " O'errun }
$$

By vines, and boundless clematis."

This plant represents in floral language the scale which weighs the sincerity of friendship. When poverty holds the beam, the multitude generally fly like chaff before the fan of a winnower; yet we hope there are none so afflicted but they may use the words of Shakspeare,

"Poverty could never draw them from me." 


\title{
PRECAUTION.
}

\author{
Golden Rod.-Solidago.
}

"In golden armour, glorious to behold."

This flower is presented as the emblem of precaution, nature having so carefully enveloped these little florets in a silky down, as to shield their nectar from the ravages of the bee.

\section{PRECOCITY.}

$\mathrm{M}_{\mathrm{AY}}$ Rose.-Rosa cinnamoma.

"Ton frais bouton, d'une aimable couleur,

Du cinnamome exhale l'ambroisie:

Et Flore en toi, par une douce erreur, Croit respirer les parfums de l'Asie."

Precocity is represented by this early and aromatic rose, which generally displays its 
beauty and dispenses its odours when Philomel begins towarble. T. Moore says in Lalla Rookh,

"Oh! sooner shall the rose of May Mistake her own sweet nightingale, And to some meaner minstrel's lay Open her bosom's glowing veil, Than Love shall ever doubt a tone, A breath of the beloved one."

\section{PREFERENCE.}

Scarlet Geranium. "Geranium boasts

Her crimson honours."

Cowper.

This emblem originated from the preference shown by florists to the cultivation of the "Genteel geranium

With a leaf for all that come." 


\section{PRESUMPTION.}

SNaP-DRAGON.-Antimhinum.

"The stern and furious lion's gaping mouth."

Columella.

This singular flower is made the symbol of presumption, from its monopetalous corolla forming a mask, which resembles the face of an animal.

"Pride, and arrogance, and the evil way, and the froward mouth, do I hate."

Proverbs viii. 13. 


\title{
PRETENSION。
}

LYTH R UM.--Lythrum.

\begin{abstract}
L'Estrange says, "Men indulge those opinions and practices that favour their pretensions."

"But if to unjust things thou dost pretend, Ere they begin, let thy pretensions end."
\end{abstract}

Denham.

\section{PRIDE.}

AMarYluis.-Amaryllis.

"In all the liveries deck'd of summer's pride."

Milton.

The splendour of these flowers has caused them to be made the emblem of pride. 


\section{Flora] Fimblems.}

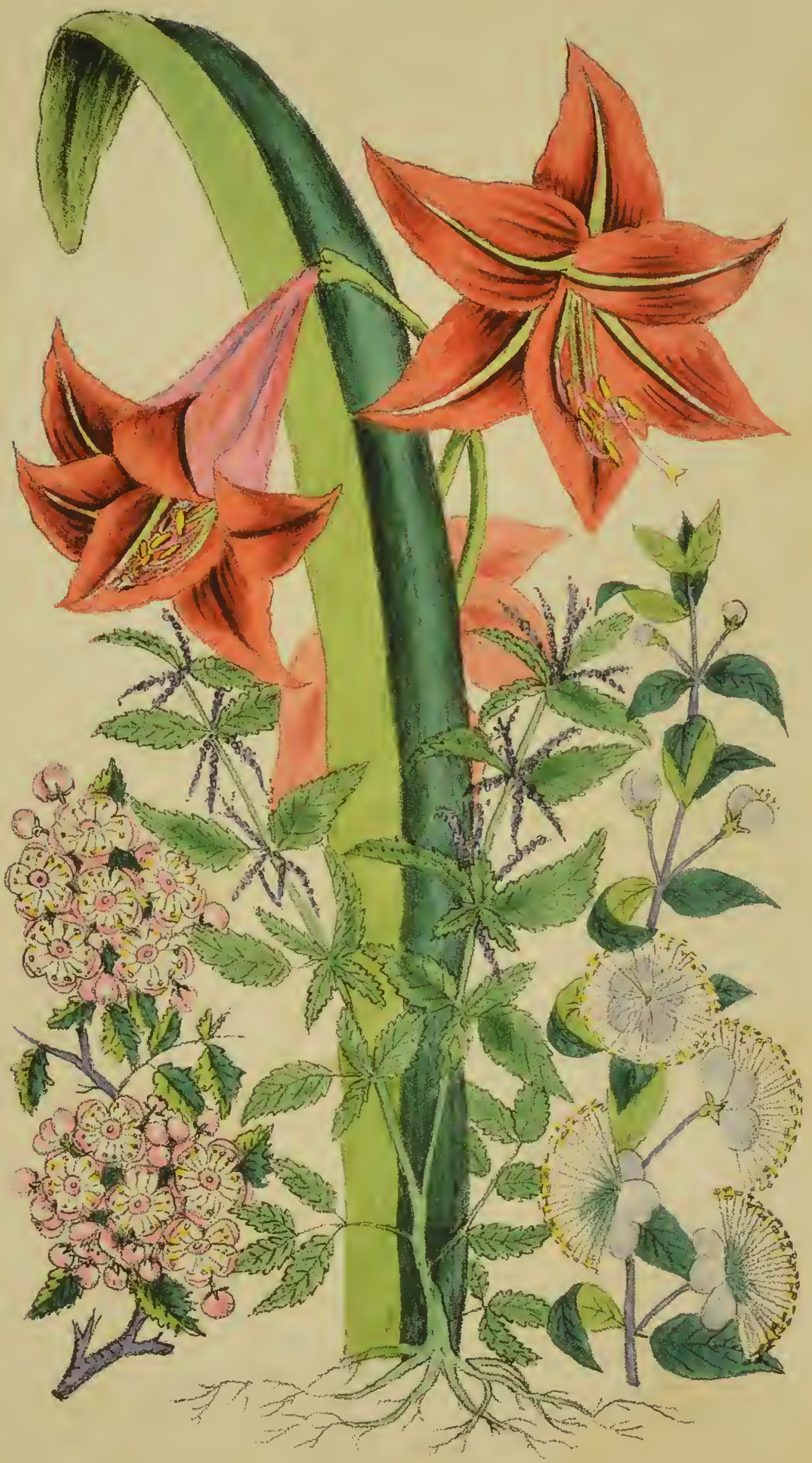

Hope separated from Love by Prite and Cmetty 

This beautiful species of the lily tribe varies not more in its colours than pride does in its qualities. Man without

"The honest pride of conscious virtue,"

is a mere animal, a sloth. Man, with pride of the insolent kind is lower than the brute. Man, who permits his self-esteem to "Peep through each part of him," is to be pitied as a frivolous insect that struts through its short summer; whilst the man, whose pride consists in the elevation of a generous heart, has the feelings of a celestial being, and must ever be regarded as the most elevated of his species.

The miser is proud of his wealth ; the spendthrift of his extravagance; the hypocrite of his cunning; the honest man of his integrity; the sloven of his filth; the beau of his neatness; the coxcomb of his dash; and the quaker of his prim formality. And arrogance is not more proud of the wounds it inflicts, than benevolence is of the balm it bestows. 
The Greek name of this plant signifies splendour; and the beauty of the flower renders it appropriate as the emblem of pride.

"Pride was not made for men; a conscious sense Of guilt, and folly, and their consequence, Destroys the claim; and to beholders tellsHere, nothing but the shape of manhood dwells!"

Waller.

\section{PROFIT.}

\section{CABBAGE.-Brassica.}

“That herb, which o'er the whole terrestrial globe Doth flourish, and in great abundance yields To low plebeian, and the haughty king, In winter, cabbage; and green sprouts in spring."

In the mercantile world, the greatest profit generally arises out of articles of necessity, or such as habit has brought into general demand; and but few if any culinary vegeta- 
bles have been as general as that of cabbage. Shakspeare says,

$$
\text { "To wail friends lost, }
$$

Is not by much so wholesome, profitable, As to rejoice at friends but newly found."

\section{PROLIFIC.}

Fig Tree; or, a Branch with Leaves and Figs.

This prolific tree, so celebrated in eastern nations, as being distinguished from all others by its bearing two successive and distinct crops of fruit in one year, and each crop being produced on a distinct set of shoots, has caused the origin of this emblematical representation: we have therefore on this account selected the fig-tree to bear the shield of our title-page, with a hope that the floral emblems may be found prolific of ge-neral amusement, and thus become productive of public favour. 


\section{PROMPTITUDE.}

Ten Weens' Stock.-Cheiranthus Ammus.

The rapidity of the growth and flowering of these plants has caused them to be made symbolical of promptitude.

"Speed the soft intercourse from soul to soul, And waft a sigh from Indus to the Pole."

Pope.

\section{PRO'TEC'TION.}

Bearded Crepis.-Crepis Barbata.

The flower-buds of this plant are protected by the linear leaves that form the beard, which has given rise to the emblem. 


\section{PROVIDENT.}

Purple Clover.-Trifolium pratense.

" Flocks, thick nibbling thro' the clover'd vale."

Thomson.

"Nature shall provide

Green grass and fatt'ning clover for their fare."

Dryden.

The provident husbandman lays up a good store of clover hay for the subsistence of his cattle during the winter months : his earliest spring pastures are also covered with this nutritious plant, which ensures both himself and his stock " a bed of clover."

The great changes which have taken place in agricultural transactions proves the justness of Atterbury's remark, that "a very 
prosperous people, flushed with great successes, are seldom so pious, so humble, so just, or so provident, as to perpetuate their happiness."

Dryden says,

"Some mien, instructed by the lab'ring ant, Provide against th' extremities of want."

The use of trefoil in armorial bearings is of great antiquity. The Dutch clover, Trifolium repens, is dedicated to St. Patrick, it being the shamrock of the Irish. 


\section{PRUDENCE.}

Mountain Ash.-Sorbus aucuparia.

"The mountain ash, whose flower-fill'd boughs

Spread like a cloud at noon ;

Whose shade is a haunted place

For the sweet airs of June.

I wreathed amid thy hair

Its berries, like the coral crown

That the sea-maidens wear."

L. E. L.

This elegant tree seems to have been selected as the emblem of prudence, from its foliage being withheld until the equinoctial winds have ceased to commit their devastations.

Peacham says, "Under prudence is comprehended that discreet, apt, suiting and disposing, as well of action as words, in their due place, time, and manner." 


\section{PURITY AND MODESTY.}

\section{White Lrty._Lilium Candidum.}

"Ye loftier lilies, bath'd in morning dew, Of purity and innocence renew Each lovely thought

\section{Barton.}

All nations and ages agree in making this flower the symbol of purity and modesty; and its beauty and delicacy has ever been the theme of admiration with the poets from the time of Solomon to the present day.

Cotton thus addressed a beautiful young girl, who was admiring these flowers:

"Lilies are by plain direction Emblems of a double kind; Emblems of thy fair complexion, Emblems of thy fairer mind. 
But, dear girl, both flowers and beauty

Blossom, fade, and die away;

Then pursue good sense and duty,

Ever-greens that ne'er decay."

\section{Thomson says,}

"Observe the rising lily's snowy grace;

Observe the various vegetable race;

They neither toil nor spin, but careless grow;

Yet, see how warm they blush! how bright they glow!

What regal vestments can with them compare?

What king so shining, or what queen so fair?"

\section{PURITY OF SENTIMENT.}

White Violet._Viola alba.

"That strain again-it had a dying fall;

$\mathrm{O}$, it came o'er my ear like the sweet breath

That breathes upon a bank of violets,

Stealing, and giving odour."

Shakspeare.

The white pink is also emblematical of purity of sentiment.

It is observed by Thomson, that

"From the body's purity, the mind

Receives a secret aid." 


\title{
QUICK-SIGHTEDNESS.
}

\author{
HAWKWEED.-Hieracium.
}

This plant is made the emblem of quicksightedness, because it was formerly given to hawks to sharpen their sight, and from hence its name originated.

It is observed by Locke, that " nobody will deem the quick-sighted amongst them to have very enlarged views in ethicks."

\section{RARITY, OR EXTRAORDINARY.}

MandRake.-Atropa Mandragora.

"— the mandrake's flow'rs

Whose root shews half a man, whose juice

With madness strikes."

\section{Columella.}

In symbolical language the mandrake is made the emblem of any thing rare or extra- 
ordinary, on account of its supposed extraordinary properties, as well as its rarity.

" La mandragore qu'on arrache, Long-temps résiste avec effort, Jette un grand cri, frappe de mort Le bras hardi qui la detache."

An observation is made in the Spectator that deserves the notice of others as well as the cultivators of flowers, it says-

"Far from being fond of any flower for its rarity, if I meet with any in a field which pleases me, I give it a place in my garden." 


\section{REASON.}

Gont's RUE._Galega officinalis.

"Dim, as the borrow'd beams of moon and stars, To lonely, weary, wand'ring travellers, Is reason to the soull : and as on high, Those rowling fires discover but the sky, Not light us here; so reason's glimmering ray Was lent, not to assure our doubtful way, But guide us upward to a better day."

Dryden.

The goat's rue, so entirely disregarded in this country, yet so highly estimated by the Italians, stands in floral hieroglyphics as the emblem of reason.

"Reason," says Hooker, " is the director of man's will, discovering in action what is good; for the laws of well-doing are the dictates of right reason." 


\title{
RECONCILIATION.
}

\author{
Filbert.-Corylus.
}

"Thou hast a brain, such as it is indeed!

On what else should thy worm of fancy feed?

Yet in a filbert I have often known

Maggots survive when all the kernel's gone."

Dorset.

Clusters of these agreeable nuts are emblematical of reconciliation, and all will allow that the cracking of filberts at reconciliation is more agreeable than the breaking of heads at dissensions.

"No cloud

Of anger shall remain ; but peace assur'd And reconcilement."

Paradise Lost. 


\section{REFUSAL.}

Striped Pink, or Carnation.-Dianthus.

"With hues on hues."

Thomson.

" and streak'd gillyflowers,

Which some call, nature's bastards : of that kind Our rustic garden's barren; and I care not To get slips of them." * * * * *

"For I have heard it said, There is an art, in their piedness, shares With great creating nature."

Shakspeare.

Ladies should think seriously before they present this emblem to their suitors. Garth says,

"Women are made as they themselves would choose;

Too proud to ask, too humble to refuse." 


\section{RELIGIOUS ENTHUSIASM.}

\section{LYCHNIs._Lychnis.}

This flower, which is frequently named cross of Jerusalem, in most of the European languages, the French calling it croix de Jérusalem; the Spanish, cruces de Jerusalem; the Italians, croce di Cavalieri; the Germans, Hierosolymorum flos; the Portuguese, cruz de Malta; all tending to dedicate it to religion, and as it appears to have been introduced by the crusaders, we present it as the emblem of religious enthusiasm.

Locke observes, that enthusiasm is founded neither on reason nor divine revelation, but rises from the conceits of a warmed or overweening brain. 


\title{
RELIGIOUS SUPERSTITION.
}

\author{
Passion Flower.-Passifiora.
}

"At rosy morn, or evening's silent hour, Some fair enthusiast views the sainted flower, When lo! to wrapt imagination's eye, Springs the sad scene of darken'd Calvary! The thorny crown the heavenly brows around, The scourging thorns, the galling cords that bound, And nails that pierced with agonizing wound; Sudden she lifts to heaven her ardent eye In silent gaze and solemn ecstacy : Then, fill'd with timid hope and holy fear, Drops on the flower a consecrated tear."

Shaw.

The Murucuia of the western world was no sooner seen in Italy, than superstition or craft, found a mysterious representation of the passion of Christ in this flower, and it received the sanctimonious titles of Flos Passionis and Christi Passionis Imago, from which our name of passion flower is derived, and the emblem formed. 
It is justly observed that the christian religion, rightly understood, is the sure foundation of true happiness; how terrible then that such a blessing should be abused by either craft or ignorance.

\section{REMORSE.}

BraubLE.-Rubus.

"The bush my bed, the bramble was my bow'r, The woods can witness many a woful storc."

Spencer.

Remorse is well represented by the thorny bramble.

“ Curse on th' unpard'ning prince, whom tears can draw To no remorse ; who rules by lion's law."

Dryden. 


\title{
RENDER ME JUSTICE.
}

\author{
Chestnut Tree.-Castanea.
}

"New cheese and chestnuts are our country fare, With mellow apples for your welcome cheer."

Virgil's Pastorals.

This tree, which affords a wholesome nourishment to the inhabitants of many countries, is not sufficiently regarded in Britain. It was however of more importance in former days, and the roasting of these nuts is mentioned by poets whose verses will ever be admired, however time may change our customs.

"Or whose discourse with innocent delight Shall fill me now, and cheat the wintry night? While hisses on my hearth the pulpy pear, And black'ning chestnuts start, and crackle there."

Milton. 
Shakspeare thus alludes to the practice.

"A woman's tongue,

That gives not half 'so great a blow to th' ear, As will a chestnut in a farmer's fire."

\section{RESEMBLANCE.}

Spiked Speedwell.-Veronica Spicala.

"Fairest resemblance of thy maker fair, Thee all things living gaze on."

Milton.

This beautiful little blue flower, familiarly known by the name of bird's eye, is made the emblem of resemblance.

In the flowers of the saints this plant is dedicated to St. Barbatus. 


\section{RESERVE.}

MAPLE.-Acer.

"On sods of turf he sat, the soldiers round;

A maple throne, rais'd higher from the ground, Recciv'd the Trojan chief."

Anis.

" The maple seldom inward sound" is made symbolical of reserve.

"To all obliging, yet reserv'd to all, None could himself the favour'd lover call." Walsh. 


\section{RESISTANCE.}

TANsy.-Tanacetum.

" Before my door the box-edg'd border lies,

Where flowers of mint, and thyme, and tansy rise."

Scott.

This balsamic plant, so celebrated of old, is made the emblem of resistance, because it was supposed to act against contagion.

"Since you can love, and yet your crror see, The same resistless power may plead for me."

Dryden.

\section{RESTORATION.}

Pericaria.-Polygonum Oriental.

"Restore me to your favour."

The seeds of this Asiatic plant were procured by M. Tournefort, from the garden of the three Churches near Mount Ararat, the spot on which the ark is supposed to have 
rested, from whence it is selected for the emblem of restoration.

" Behold the different climes agree, Rejoicing in thy restoration."

Dryden.

\section{RETURN OF HAPPINESS.}

Lily of the VAlLey.—Convallaria majalis.

“ and ye, whose lowlier pride,

In sweet seclusion seems to shrink from view,You of the valley nam'd, no longer hide

Your blossoms meet to twine the brow of purest bride."

Barton.

This flower, whose odour is as agreeable as its form is elegant, announces the happy season of May, when

" new verdure clothes the plain,

And earth assumes her transient youth again."

Milton.

"Then the sweet lily of the vale

In woodland dells is found,

While whisp'ring winds its sweets exhale,

And waft its fragrance round." 


\section{REWARD OF VIRTUE.}

Crown of Roses.

"And on hire hed, ful semely for to see

A rose gerland fresh and wel-smelling."

Chancer.

This emblem originated from the festival of Salency, where a chaplet of roses is annually given to the most virtuous daughter of the hamlet.

"If there's a power above us, And that there is all nature cries aloud Thro' all her works, he must delight in virtue, And that which he delights in must be happy."

Addison. 


\section{RICHES.}

WHEAT.-Triicum.

" Of golden wheat, the strength of human life."

Philips.

Floral hieroglyphics have not a more appropriate emblem than that of representing riches by this gift of Ceres.

Without content no man can be rich, and it will always be found that there is a greater proportion of wealthy poor people, than of rich in content.

"What riches give us, let us first enquire,

Meat, fire, and clothes; what more? meat, clothes, and fire."

Pope. 


\section{RIGOUR.}

Various culouren Lantana.-Lantana Camara.

" Rigour makes it difficult for sliding virtue to recover."

Self imposed rigour, is a presumptuous pride, that is both injurious and offensive to pure religion.

\section{RUPTURE.}

Blue-flowered Greek Valerian.-Polemomium cœruleum.

Violent ruptures are more fiequently produced from frivolous disputes than from either reason or justice. 


\section{RUSTIC BEAUTY.}

Frencir Honeysuckie.-Hedysarum cornoarium.

Rustic beauties lose all their charms when removed out of their natural situations. As flowers of the fields appear weeds in the garden, so will village belles look like foils in a court assembly. 


\section{SCULPTURE.}

Hoya.-Iloya camosa.

"Then sculpture and her sister arts revive,

Stones leap'd to form and rocks began to live."

Pope.

The artists who give in substance what the poets give in idea must not want a symbol to their ensign. And as we have not the power to convoke a general meeting of these creative artificers, to ascertain which of the undisposed of flowers they would prefer, we assume the privilege of registering their floral emblem, in our little college of heraldic flowers, without either their assent, or the assistance of the pursuivant or garter king of arms.

We have gathered this emblematical flower of sculpture in Asia, it being the quarter of the globe where the arts first originated. And 
the hoya appears to have been formed by nature, when in a frolic she tried to mimic art, as it bears more the resemblance of sculpture than of vegetation. When this ornamental climbing plant embellishes the columns of our conservatories, we may truly say in the words of Milton---

"Nor did there want

Cornice, or freeze, with bossy sculpture graven."

\section{SECRECY.}

This emblem is formed by a full blown rose being placed over two buds.

\section{" It was told under the rose."}

It is related in mythological history that the god of love made Harpocrates, the god of silence, a present of the first rose, to bribe him not to divulge any of the private practices of his mother Venus. Hence the rose was made the symbol of silence, and it became 
a custom with the ancients to place a rose above their heads in their banqueting rooms, in order to banish restraint, as it expressed that nothing would be repeated that was said under the rose.

"For secrecy no lady closer."

Shatispeare.

\section{SENSUALITY.}

SPANISH JASMINE.-Jasminum grandiflorum.

"Here jasmines spread the silver flower, To deck the wall or weave the bower."

Cotton.

This highly odorous flower represents an immoderate desire for sensual gratifications.

Youth spent in sensuality, ends in premature old age, accompanied by disease of body, and infirmity of mind. 
When we can no longer maintain folly, neglect is sure to approach us, who never fails to present her ungracious cup of bitters.

\section{SEPARATION.}

Asit-t.eaved Trumpet Fower.-Bignonia radicans.

"Did you not hear

A buzzing of a separation

Between —_ and -

Shakspeare.

Separations are eagerly announced by the trumpets of scandal and ill-nature, who by their discordant sounds, frequently prevent the possibility of a re-union.

The gay corollas of this North American plant drop off, leaving the pistilum destitute of protection, and hence it is presumed the emblem was devised, for where attachment is so slight, separation becomes easy. 


\title{
SEVERITY, OR RIGOUR.
}

\author{
Branch of Thorns.
}

"Thorns and thistles shall it bring forth."

"Spare the rod and spoil the child," is a proverb happily gone out of favour, since it has been so generally known that birch manure produces those sour and obstinate weeds that destroy the fair flowers from which we might otherwise have expected agreeable fruit.

\section{SLEEP OF THE HEART.}

White Poppy.-Papaver Somniforum.

"From the poppy I have ta'en

Mortal's balm, and mortal's bane!

Juice, that creeping through the heart, Deadens ev'ry sense of smart." Mrs. M. Robinson.

This somniferous plant, which mitigates pain, damps also the energies of the mind, 
and deadens all the warmer sensations of the heart.

"For is there aught in sleep can charm the wise, To lie in dead oblivion, losing half

The fleeting moments of too short a life-

Total extinction of the enlightened soul."

Thomson.

\section{SICKNESS.}

Anenone.-Anemone.

"So sudden fades the sweet Anemone.

The feeble stems, to stormy blasts a prey, Their sickly beauties droop and pine away. The winds forbid the flow'rs to flourish long, Which owe to winds their name in Grecian song."

Eusden's Ovid.

The anemone was made the emblem of sickness, in allusion to the fate of Adonis, or, as some suppose, from its being anciently worn against disease.

"Trust not too much your own resistless charms, Those age or sickness soon or late disarms." 


\section{SILENCE.}

Lotus flower, or Water Lily.- Nymphea.

"Where blanicless pleasures dimple quiet's clieck, As vater-lilies ripple a slow stream!"

\section{Coleridge.}

" I suffer not a woman to teach, nor to usurp authority over the man, but to be in silence."

1 Timolhy ii. 12.

We present this aquatic plant as the emblem of silence, since the antiquarians assure us, that they recognize this flower on the head of Harpocrates.

Love glides silently upon us, and the Indians feign that Cupid was first seen floating down the Ganges on the Nymphara Nelumbe

"Down the blue Ganges laughing glide

Upon a rosy lotus wreath,

Catching new lustre from the tide,

That with his inage shone beneath."

'T. Moore. 
The lotus is an object of supreme veneration in all the mythological systems of the east especially in that of the Hindus.

The sacred name of this plant is Pedma, and it is pretended that Brahma was born in a lotus, when he created the world, wherefore it is regarded as the symbol of creative power.

"And thy own pedma, roseate flower of light, Emblem and cradle of creative might."

$$
\text { C. Grant. }
$$

"This plant, (says Mr. Knight,) being productive of itself, and vegetating from its own matrice, without being fostered in the earth, was naturally adopted as the symbol of the productive power of waters, upon which the active spirit of the creator operated, in giving life and vegetation to matter." 


\section{SIMPLICITY.}

A full blown Eglantine, or Single Rose.

"Of old, the rose on lowly bramble sprung."

De Lille.

"And, blushing, the uncultured rose, Hangs high her beauteous blossoms."

Mrs. C. Smith.

The single rose presents to the botanist, all those natural beauties of the flower, which are lost in its highly cultivated double state.

Thus simplicity will ever have charms for true discernment. Lavinia won Palemon's love

"Veil'd in a simple robe." 


\section{SINCERITY.}

Garden Chervil._Scandix cerefolium.

"The thoughts of past pleasure and truth, The best of all blessings below."

The ancients affirm, that this herb, when eaten, causes cheerfulness without inebriety; and hence it was made the symbol of sincerity. 


\section{SINGULARITY.}

Cock's-comb, or Crested Anarantu.

Celosia Cristata.

" ___ plants, divine and strange,

That ev'ry day their blossoms change,

Ten thousand lovely hues!

With budding, fading, faded flowers,

They stand, the wonder of the bowers,

From morn to evening dews."

This singular amaranth is a native of flowery lands, being common in China, Japan, and some parts of Persia.

Singularity is frequently adopted by those who have no other claims to public notice; but it is justly observed, that to be singular in any thing that is wise and worthy, is not a disparagement but a praise. 


\section{SNARE.}

Dragon Plant.-Arum dracunculus.

"Oh! wander not where dragon Arum show'rs Her baleful dews, and twines her purple flowers, Lest round thy neck she throw her snaring arms, Sap thy life's blood, and riot on thy charms. Her shining berry, as the ruby bright, Might please thy taste, and tempt thy eager sight, Trust not this specious veil; beneath its guise, In honey'd streams, a fatal poison lies." Mrs. F. A. Rowden.

The above lines were penned to caution children against the dangers of this beautiful vegetable production. But as children of a full growth are frequently entangled, we shall caution them in the words of Dryden, who says,

"The spreading snare for all mankind is laid, And lovers all betray, or are betray'd." 



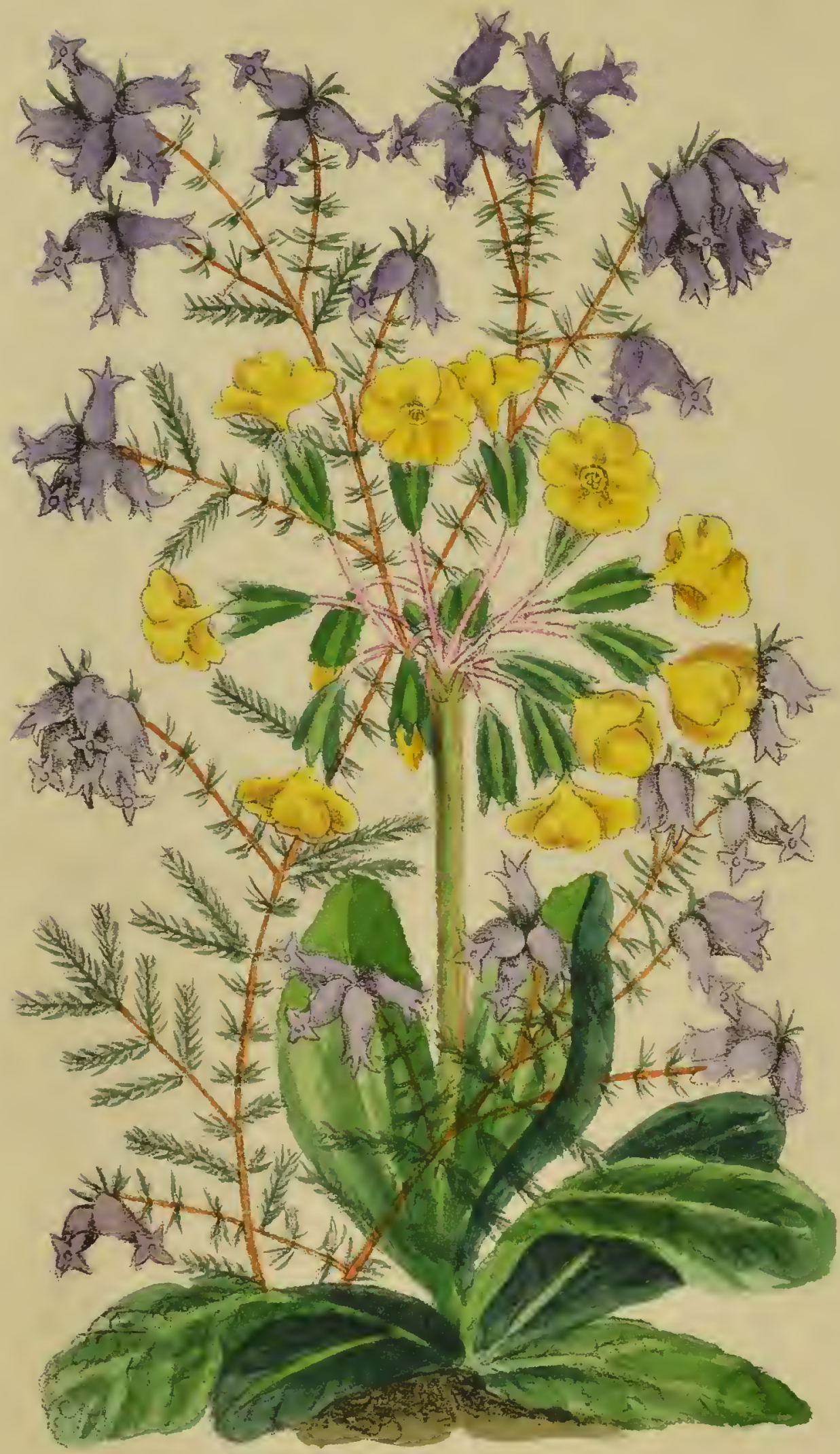

Pensiveness arising from Sotitude. 


\section{SOLITUDE.}

Heati.-Erica.

« The Erica here,

That o'er the Caledonian hills sublime, Spreads its dark mantle, (where the bees delight, To seek their purest honey,) flourishes.

Mrs. C. Smith.

"To you, ye wastes, whose artless charm

Ne'er drew ambition's eye,

'Scap'd a tumultuous world's alarms,

To your retreats I fly.

“ Deep in your most sequester'd bower,

Let me at last recline;

Where solitude, mild modest power,

Leans on her ivy'd shrine."

Beattie.

The beautiful heath with its purple bells, has been chosen for the emblem of solitude, because it grows only in poor acrid soil, consequently in dreary situations.

"What call'st thou solitude? Is not the earth

With various living creatures, and the air, Replenish'd, and all these at thy commiand, To come and play before thee."

Milton. 


\title{
SORROWFUL REMEMBRANCES.
}

\author{
A nonis.-Adonis.
}

"Adonis dont la vie eut des termes si courts Qui fut pleuré des ris, qui fut plaint des amours."

La Fontaine.

Fable tells us that Adonis stained with his blood the flower that bears his name, and hence it has been made the emblem of sorrowful remembrances.

" Then on the blood sweet nectar she bestows, The scented blood in little bubbles rose:

Little as rain drops, which flutt'ring fly, Born by the winds along a low'ring sky. Short time ensu'd, till where the blood was shed, A flow'r began to rear its purple head."

Eusden's Ovid.

Some poets make this flower symbolical of the chase, in allusion to Adonis's love of hunting.

" On the discolour'd grass Adonis lay, The monster trampling o'er his beautious prey. * * * * * * *

Yet dares not Venus with a change surprise, And in a flow'r bid her fall'n hero rise." 


\section{SOURNESS.}

BARBERRY.-Barberis vulgaris.

"Sullen and sour, with discontented mein, Jocasta frown'd."

$$
\text { Pope. }
$$

This acid fruit with its sour leaves, is emblematical of the temper that is soured by peevish asperity.

Too great a propensity to seriousness, is apt to engender sourness.

\section{SPLENDOUR.}

Scarlet Nasturtium.-Thopoolum.

This Peruvian plant, which wears the gay livery of the worshippers of the Sun, has, 
from its gold like colour, been made the type of splendour or magnificence.

How poor is the magnificence of gold in comparison to a splendid sun-set! Yet, how we neglect the grandeur of the heavens to run after the momentary pageantry of men, the whole power of whose greatest dazzle is insufficient to ripen a gooseberry; and leaves us without bestowing either warmth or nourishment.

"Thus unlamented pass the proud away, The gaze of fools, and pageant of a day."

Pope.

\section{SPLEEN.}

Common Fumitory.-Fumaria officinalis.

We know not why this weed of our corn fields, has been selected for this angry emblem. 
"The spleen with sullen vapours clouds the brain, And binds the spirits in its heavy chain; Howe'er the cause fantastic may appear, Th' effect is real, and the pain sincere."

Blackmore.

\section{STOICISM.}

Box.-Burus.

"How goodly looks Cytorus, ever green, With boxen groves."

\section{Dryden's Virgil.}

This tree is made symbolical of a Stoic, on account of the firmness of its wood, which, like the Stoics of old, cannot be warped.

"Nor box, nor limes, without their use are made, Smooth-grain'd, and proper for the turner's trade;

Which curious hands may carve, and seal with ease invade."

Virgil. 


\section{STRENGTH.}

Cenar Tree.-Pimus Cedrus.

"Cedars here,

Coeval with the sky-crown'd mountain's self, Spread wide their giant arms."

Mason.

The use of this wood for all purposes requiring strength, has been proverbial from the time of Solomon to the present day.

"Yet heaven their various plants for use designs, For houses, cedars ; and for shipping, pines."

Virgil. 


\title{
SUCCESS CROWN YOUR WISHES.
}

\author{
Coronilla.-Coronilla.
}

"Thy wish, exactly to thy heart's desire."

Milton.

"My crown is call'd content;

A crown it is that seldom kings enjoy."

Shakspeare.

This little shrub, which enlivens the fields of Spain and Italy, derives its name from corona, a crown, because the head of each of its branches is crowned by a corymb of golden flowers. We have, therefore, placed it in this collection, as emblematical of our friendly wishes. The gay coronilla, that dispenses its sweet odours so agreeably through our conservatories, we hope will shortly attract the notice of some poet, whose pen may happily describe its beauties, and in return for the verse, we will bestow on him the motto this flower is made to express. 


\title{
SUPERSTITION.
}

\author{
Vervian.-..Verbena.
}

" The nightshade strews to work him ill, Therewith the vervian and her dill, That hind'reth witches of their will."

Drayton.

In superstitious ages this plant was not only used in religious ceremonies, but was thought to possess the power of repelling witches and enchanters.

“A rev'rent fear, such superstition reigns Among the rude, ev'n then possess'd the swains."

Dryden.

In ancient times the ambassadors or heralds at arms wore crowns of vervian when they went to denounce war, or give defiance to their enemies.

"A wreath of vervian heralds wear, Amongst our garlands named, Being sent that dreadful news to bear, Offensive war proclaimed."

1)iayton. 


\title{
SUPERSTITIOUS SANCTITY.
}

\author{
ST. JoHN's-worT.-IIypericum. \\ "Hypericum all bloom." \\ Cowper. \\ "I hold you as a thing enskied and sainted." \\ Shakspeare.
}

The name of this plant seems to have given the idea of the emblem.

$$
\text { "At his touch, }
$$

Such sanctity hath heaven given his hand, They presently amend."

Shakspeare. 


\section{SURPRISE.}

BrTons.-Betonica.

"He has as many virtues as betony."

This proverb is common in Spain, and some other countries where the betony is still regarded for its efficacy in curing many complaints. The use of this plant is, however, subject to give a kind of intoxication, which causes the patient to commit all sorts of extravagancies, and the leaves when dried and powdered into the form of snuff, produces immoderate sneezing, from which cause the emblem has been devised. 


\section{SUSPICION.}

Mushroom.-Fungus.

"And fungus fruits of earth, regales the sense With luxury of unexpected sweets."

Cowper.

'The dangerous properties of some species of this family of plants have caused the emblem, for suspicion is a poison that destroys the quietude of those who cultivate it. Lord Bacon says,

"Suspicions amongst thoughts are like bats amongst birds, they ever fly by twilight; they are to be repressed, or at least well guarded, for they cloud the mind." 


\title{
SWEET, OR MILD DISPOSITION.
}

\author{
MALLOW.-Malva.
}

"Exoneraturas ventram mihi villica Malvas Astulit, et varias, quas habet hortus, opes."

Martial. Lib. 10.

The mild and healing properties of this plant have caused it to be made the symbol of this amiable quality.

"Nothing reserv'd or sullen was to see, But sweet regards, and pleasing sanctity; Mild was his accent, and his actions free."

Dryden。 


\section{TALENT.}

White Pink.-Dianthus.

"Sweet flower, beneath thy natal sky

No fav'ring smiles thy scents invite;

To Britain's worthier regions fly,

And paint her meadows with delight."

Shaw.

This flower, so richly gifted with odour, is emblematical of those persons who benefit society by their talents.

"Each pink sends forth its choicest sweet Aurora's warm embrace to meet."

Mrs. M. Robinson. 


\section{TARDINESS.}

FlaX-Leaved Goldy-Locks.-Chrysocoma Linosyris.

"Cry mercy, lords, and watchful gentlemen, That you have ta'en a tardy sluggard here."

Shakspeare.

This British plant, whose blossoms sleep until other flowers have sported their day, is more conspicuous through its tardiness than its beauty, like those who reserve their revels until the time of rest, as if aware that their attractions would be overlooked if associated with the multitude. 


\section{TASTE.}

Scarlet Fuchsia.-Fuchia Corcinea.

"Elegant, with ease."

We place the fuchsia in the floral emblems as the symbol of taste; for, with its richlycoloured blossoms, there is a peculiar harmony and beauty in the unassuming appearance of the flowers, which hang with so much gracefulness amongst the foliage. 


\section{TEARS.}

Heleniun.-Helenium.

"Sweet drop of pure and pearly light!

In thee the rays of virtue shine;

More calmly clear, more mildly bright,

Than any gem that gilds the mine.

Benign restorer of the soul!

Who ever fly'st to bring relief,

When first she feels the rude control

Of Love or Pity, Joy or Grief."

Rogers.

This plant is named after the fair daughter of Leda, whose beauty caused the Trojan war, and from whose tears it is said to have sprung; which gave rise to the emblem. 


\section{TEMPERANCE.}

Azalen.-Azalea.

"Make temp'rance thy companion; so shall health Sit on thy brow."

This beautiful family of American plants were named Azalea, in allusion to their growing naturally in a dry soil only.

They flourish in this country only when planted in poor heathy ground; for when fed by the richly manured earth of English gardens they sicken and decay, disappointing the hopes of the planter. We have therefore made the Azalea emblematical of "Temperance, that virtue without pride, and fortune without envy, which gives indolence of body and tranquillity of mind ; the best guardian of youth, and support of old age."---Temple. 


\section{THOUGHTS.}

\section{YOU OCCUPY MY THOUGHTS;}

$$
\text { or, }
$$

\section{PENSEZ A MOI.}

Pansée, or Heart's Ease.-Viola tricolor.

“ And there are pansies, that's for thoughts."

Shakspeare.

"And thou, so rich in gentle names, appealing To hearts that own our nature's common lot; Those, styl'd by sportive fancy's better feeling

'A Thought,' 'The Heart's Ease,' or 'Forget me not.."

Barton.

Thoughts are not more numerous than the varieties of this little sportive flower, since it is difficult to find two alike, although we generally see

" -___ The garden's gem

Heart's ease, like a gallant bold, in his cloth of purple and gold."

\section{Leigh Ilunt.}

In the flowers of the saints the pansée is dedicated to St. Euphrasia. 
Floral Emblems

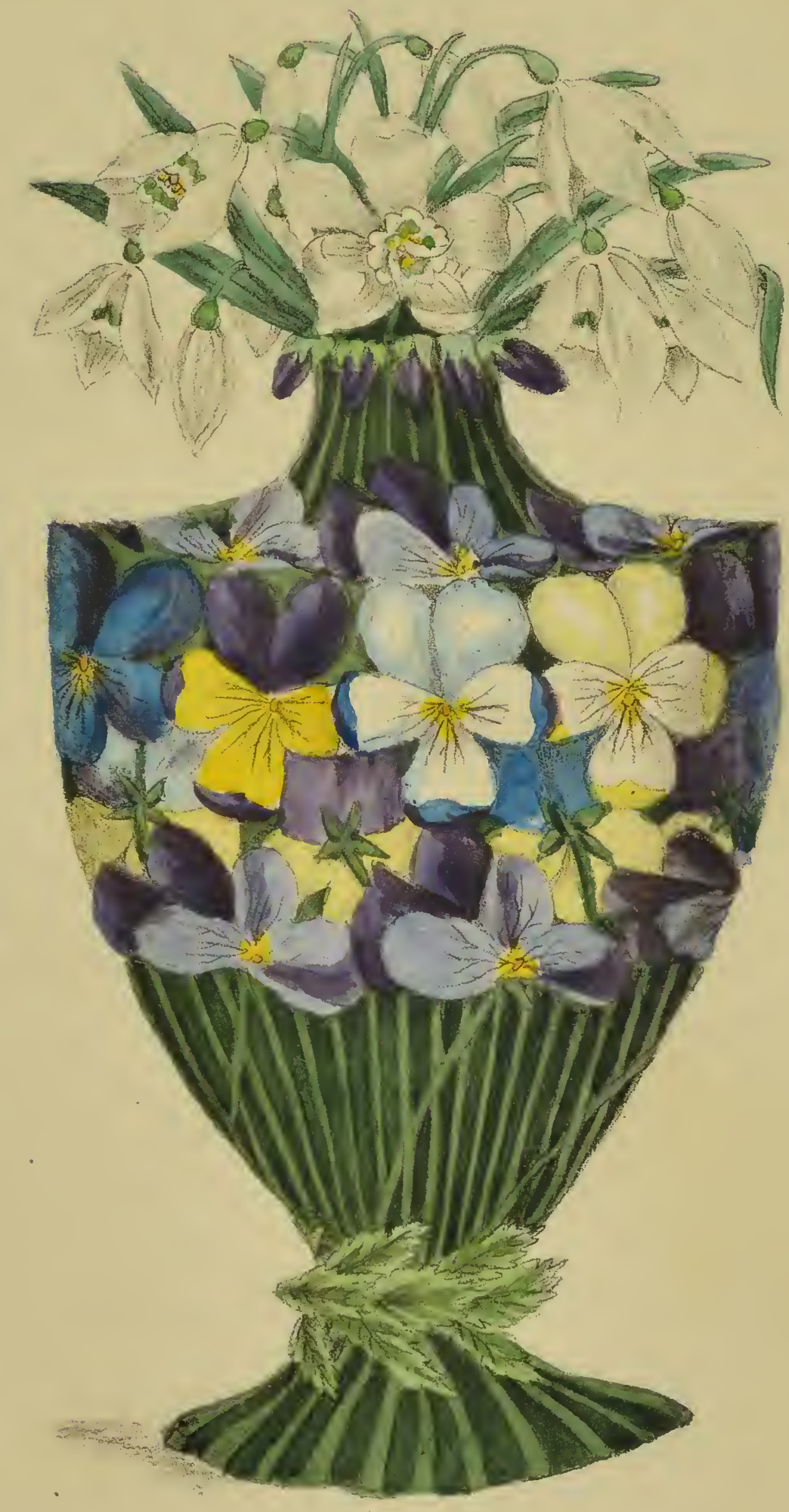

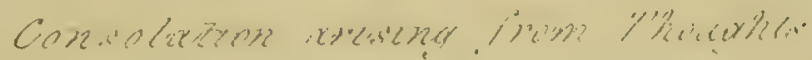




\section{TIME.}

Wirte: Poplar.-Populus canescens.

"And poplar, that with silver lines its leaf."

Cowper.

This rapid growing tree stands as the symbol of 'Time in floral language.

"Come what come may,

Time and the hour runs through the roughest day."

Shakspeare. 


\section{TIMIDITY.}

Marvel of Peru. - Mirabilis.

"Solitaire amante des nuits, Pourquoi ces timides alarmes, Quand ma muse au jour que tu fuis S'apprête à révéler les charmes?

$\mathrm{Si}$, par pudeur, aux indiscrets Tu caches ta fleur purpurine, En nous dérobant tes attraits, Permets du moins qu'on les dévine."

This Belle de nuit is made the emblem of timidity, because it cannot endure the gaze of Sol, which enlivens and expands most other flowers.

"The infant flames, whilst yet they were conceal'd In tim'rous doubts, with pity I beheld;

With many smiles dispell'd the silent fear, That durst not tell me what I dy'd to hear."

Prior. 


\section{TREASON.}

Whortle-Berry.--Vaccimium Myrtillus.

"Come, stain your face with whortle-berry."

This emblem of treason is only found on dreary heaths and mountainous situations, where its fruit has often been used to disguise the face of the proscribed. 


\section{TRUTH.}

Butter sweet Nrgutsuanf.-Solamim Dulcamara.

"The first great work

Is, that yourself may to yourself be true."

Roscommon.

However delightfully sweet truth must ever appear, it is frequently found a bitter draught to those to whom it is presented; and from this cause we presume the emblem has been established. 


\section{UNANIMITY.}

$$
\text { PhLox.-Phlox. }
$$

"Unanimous, as sons of one great sire."

Milton.

This North American plant is presented as the emblem of unanimity, in allusion to the united forms of the flowers, whose clustered corymbs form an umbel; and also from the United States, from whence we procured them. 


\section{UNEASINESS AND JEALOUSY.}

Garden MARYGOLD._Calendula officinalis.

"The marygold, that goes to bed with the sun, And with him rises weeping."

Shakspeare.

"And jealousie,

That wered of ycleve goldes a gerlond, And had a cuckowe sitting in her hand."

Chaucer.

This flower, which closes its petals with the last smile of the sun, is given as a representative of jealousy on account of its yellow colour.

Dryden says,

“Small jealousies, 'tis true, inflame desire;

Too great, not fan, but quite blow out the fire." 
Spencer pictures,

"Gnawing jealousy, out of their sight,

Sitting alone, his bitter lips did bite."

Shakspeare calls this monster

"Green-eyed jealousy."

\section{AN UPSTART}

Is represented by a mushroom on a green turf. The great Verulam observes, "Mushrooms come up in a night, and yet they are unsown ; and therefore such as are upstarts in state, they call in reproach mushrooms."

"The humble mushroom, scarcely known, The lowly native of a country town."

Dryden. 


\section{USELESSNESS.}

Sprre Hypericum Frutex.-Spirce hypericifolia,

As this plant has not yet been turned to any profitable purposes in Europe, it stands as the degrading emblem of uselessness.

On close investigation, we find every plant of some utility in its natural situation, although they are frequently cursed as weeds when they do not exactly meet our wants.

"So have I seen the lost clouds pour Into the sea an useless show'r;

And the vext sailors curse the rain

For which poor shepherds pray'd in vain."

Waller. 


\section{U'TILITY.}

\section{Dried Flax.-Limum.}

"The matron, at lier nightly task

With pensive labour draws the flaxen thread."

Thomson.

The ingenuity of man has rendered this simple plant of the greatest utility, hence the emblem.

The Egyptians appear to have been the inventors of weaving linen cloth. The Athenians, who were an Egyptian colony from Sais, followed the custom of their ancestors, by applying themselves to raising flax for the same purpose; they therefore continued to worship Minerva, who was also styled Ergatis, or the work-woman, for her excellency in spinning and weaving; and who is supposed to be no other than the Egyptian Isis; for the 
Egyptians, to remind the people of the importance of their linen manufactory, exposed in their festivals an image, bearing in its right hand the beam or instrument round which the weavers rolled the warp of their cloth. This image was called Minerva, from Manerra, a weaver's loom. The name of Athene, that is also given to this goddess, is the very word denoting in Egypt the flaxen thread used in their looms. Near this figure, which was intended to warn the inhabitants of the approach of the weaving or winter season, they placed another of an insect, whose industry is supposed to have given rise to this art, and to which they gave the name of Arachne, (from arach, to make linen cloth), to denote its application. All these emblems, transported to Greece, were by the genius of a people fond of the marvellous, converted into real objects, and indeed afforded ample room for the imagination of the poets to invent the fable of the transformation of Arachne into a spider. 
Ovid describes Arachne as

"One at the loom so exquisitely skill'd That to the goddess she refused to yield. Low was her birth, and small her town, She from her art alone obtained renown."

"Providence," says Moore, "would only enter mankind into the useful knowledge of her treasures, leaving the rest to employ our leisures." 


\section{VARIETY}

China Aster, or Chinensis Starwort. Aster Chinesis.

"As from a cloud his fulgent head And shape star-bright appear'd."

The diversities of colour and variations of this flower have caused the emblem.

"All sorts are here that all th' earth yields; Variety without end."

Milton. 


\section{VICE.}

Darnel, or RAy-grass.-Lolium.

"No fruitful crop the sickly fields return;

But oats and darnel choak the rising corn."

Dryden.

This degenerated species of corn frequently springs up to the injury of the crops, as vice will rear its head in the midst of virtue, for

"No vice so simple, but assumes

Some mark of virtue on its outward parts."

Shakspeare. 


\section{VICTORY.}

Palm._Palma.

"Get the start of the majestic world, And bear the palm alone."

Shakspeare.

The branches of palm-trees were anciently carried before the conquerors in warlike processions to show that they had overthrown the enemy; and hence the palm became the symbol of victory and superiority.

"In love, the victors from the vanquish'd fly; They fly that wound, and they pursue that die."

Waller. 


\section{VIRTUE.}

\section{Mint.-Mentha.}

"Then rubb'd it o'er with newly-gather'd mint, A wholesome herb, that breath'd a grateful scent."

The medicinal properties of this herb were formerly held in such high estimation, that the plant became the emblem of virtue.

"Virtue only makes our bliss below."

$$
\text { Pope. }
$$

\section{VIVACITY.}

HOUSELEEK.-Sempervivum tectorum.

"The sprightly Sylvia trips along the green;

She runs, but hopes she does not run unseen."

Pope.

This emblem is given to the houseleek, because it maintains its vivacious nature even 
on the hot tiles of cottage roofs. In such situations it generally bespeaks the residence of some good old dame, well skilled in simples.

"Of simples in these groves that grow,

We'll learn the perfect skill;

The nature of each herb to know,

Which cures, and which can kill."

Drayton's Cynth.

\section{VOLUPTUOUS LOVE.}

Moss Rose.

"The rose that hails the morning,

Array'd in all its sweets,

Its mossy couch adorning,

The sun, enamour'd, meets."

This rose, on which Flora has bestowed so many of her choicest gifts, has been selected to represent voluptuous love in floral language.

" ' Then,' said the rose, with deepened glow,

'On me another grace bestow.___' 
Floral Enolems

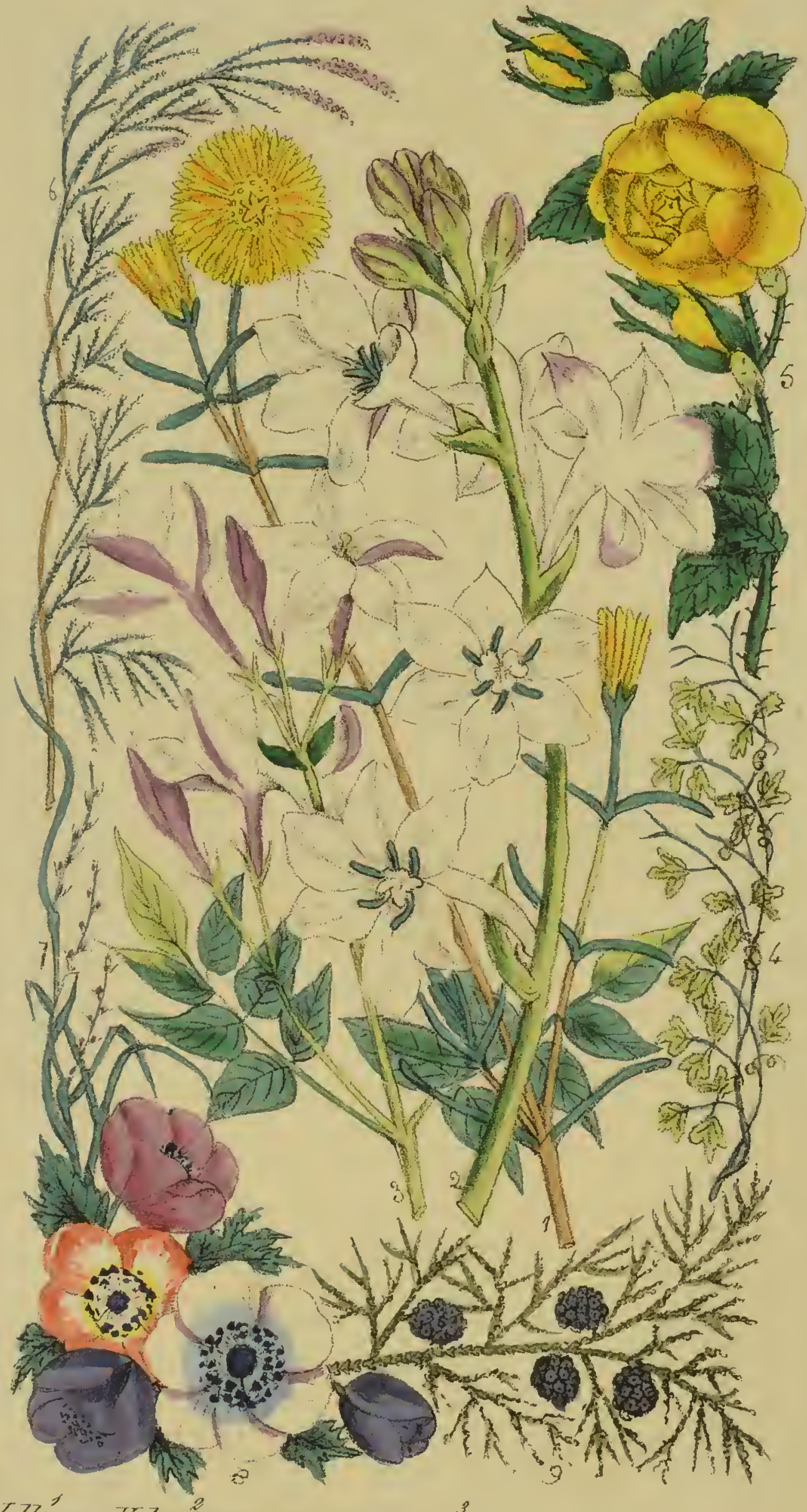

Idléness, Votuphüroisness and Sensuatizy, encompassed by

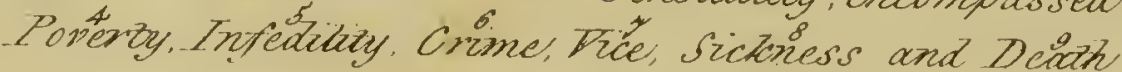


The spirit paused in silent thought-

What grace was there that flower had not?

'Twas but a moment-o'er the rose

A veil of moss the angel throws;

And, robed in nature's simplest weed,

Can there a flower that rose exceed ?"

\section{Of voluptuousness, Shakspeare says,}

"Had I a dozen sons, I had rather eleven died nobly for their country, than one voluptuously surfeit out of action."

\section{VOLUPTUOUSNESS.}

Turerose.-Polyanthes tuberosa.

"The tuberose, with her silver light,

That in the gardens of Malay, Is called the mistress of the night; So like a bride, scented and bright,

She comes out when the sun's away."

T. Moore.

"Des bords de l'Orient je suis originaire;

L'astre brillant du jour se peut dire mon père.

Le printemps m'est rien; je ne le connais pas, Et ce n'est point à lui que je dois mes appas.

Je l'appelle, en raillant, le père des fleurettes, Du fragile muguet, simples violettes, 
Et de cent autres fleurs quis naissent tour-à-tour, Mais de qui les beautés durent à peine un jour. Voyez-moi seulement : ma fraîcheur est exquise, J'ai le teint très-uni, ma taille est fort bien prise, Des roses et des lis j'ai le brillant éclat, Et du plus beau jasmin le lustre délicat; Je surpasse, en odeur, et la jonquille et l'ambre, Et le plus grand des roîs me souffre dans sa chambre."

Madame Scudéry.

The highly odoriferous properties of this Eastern flower has caused it to be a representative of voluptuousness in the floral emblems of the Persians.

"Dans ses bras amoureux l'imprudente la presse: Quand tout à coup, saisis d'une douce languer, Ses bras sont accablés sous le poids du bonheur A ce trouble inconnu la jeunesse alarmée, Veut éviter les traits du dieu qui l'a charmée; Mais, hélas! ses combats se changent en plaisirs, Ses craintes en espoir, ses remords en désirs : Confuse, elle retombe au milieu de ces chaînes: Un charme involontaire accompagne ses peines: Elle voudrait haïr, elle ne peut qu'aimer ; Son cour cherche le calme, et se laisse enflammer. C'est alors qu' à ses yeux se decouvre l'abîme: Mais un chemin de fleurs la conduit jusqu'au crime.'

Bermis, Epître. 


\title{
VORACIOUSNESS.
}

\author{
LuPIN.-Lupimes.
}

\section{-_ "Tristisque lupini}

Sustuleris fragiles calamos."

\section{Virgil.}

The ancients named this plant Lupinus, from Lupus, a wolf, on account of its voracious nature, which is such, that it draws in all the nourishment of the soil to feed its own growth, and consequently, destroys other vegetation; but in doing so, it forms an excellent manure for poor and foul lands.

"Where stalks of lupins grew,

'Th' ensuing season, in return, may bear

The bearded product of the golden year."

Dryden. 


\section{VULGAR MINDS.}

African Marygold.-Tagetes erecta.

"Open afresh your round of starry folds, Ye ardent marigolds!"

Keats.

These flowers have only their gaiety to recommend them, since their odour is more offensive than agreeable, and may be compared to those persons who depend more on their wardrobe than their conduct for making themselves pleasing. We therefore present them as emblematical of vulgar minds.

An attention to the mode of dress of the age we live in, is due to society: but to depend entirely on it, is valuing our understanding as naught. 


\section{WAR.}

Common Milfoil, or Yarrow.-Achillea Millefolium.

— "War's a game, which were their subjects wise, Kings would not play at."

Cowper.

The ancients named this plant after Achilles, the celebrated Grecian hero, on which account it has been made the emblem of war.

"O War, what art thou?

After the brightest conquests, what remains

Of all thy glories? For the vanquish'd-chains :

For the proud victor-what? Alas! to reign

O'er desolated nations."

IIammah More. 


\section{WEAKNESS.}

Moschater.t.-Adoxa Moschatellina.

The generic name of this hollow tuberous rooted plant, signifies ignoble.

"If weakness may excuse,

What murderer, what traitor, parricide, Incestuous, sacrilegious, but may plead it?

All wickedness is weakness."

Milton.

\section{WIDOW, OR WIDOWHOOD.}

Sweet Sultan, Honey-flower, or Sweet Scabious. Srabiosa atropurpurea.

The Italians name this flower Fior della Vedova, and the French Fleur deVeuve, (widow's Hower, ) on account of its sable hue; hence the emblem, as also the symbolical expression of "I have lost all." 


\section{WINTER OF AGE.}

Guelder-rose.-Viburmum opulus.

"Her silver globes, light as the foamy surf That the wind severs from the broken wave."

Cowper.

"The snow-ball which celipses The white bosom of Venus."

This cold-coloured, abortive flower is made to represent the age which banishes gaiety and warm desire.

"After summer, evermore succceds

The barren winter, with his nipping cold."

Shakspeare.

"And on this forehead, (where your verse has said The loves delighted, and the graces play'd,) Insulting age will trace his cruel way, And leave sad marks of his destructive sway." 


\section{WISDOM.}

\section{MUlBERRY-TREE.-Morbus.}

"And that old mulberry that shades the court Has been my joy from very childhood up."

\section{Kirlie White.}

" the green leaf'

Which feeds the spinning worm."

Pliny observes, that the mulberry-tree was esteemed the wisest of all the trees, because it never expanded its buds until all fear of frost was past, and hence the origin of the emblem.

"Pronounce him blest, my muse, whom wisdom guides In her own path to her own heavenly seat; Through all the storms his soul securely glides, Nor can the tempest, nor the tides

That rise and roar around, supplant his steady feet." Wrills. 


\section{WITCHCRAFT.}

Enchanter's Night-sHadi.-Circa't.

"The night-shade strews to work him ill."

Drayton.

$$
\text { "O, who can tell }
$$

The hidden power of herbes, and might of magic spell!" Spenser.

The fruit of this plant has little hooks by which it lays hold of passengers by their garments, and thus drawing them to it; on this account it was named Circea, after Circe the enchantress, so celebrated of old for drawing the unwary into her power.

"Tis now the very witching time of night."

"I'll witch, sweet ladies, with my words and looks."

Shakspeare.

"For Circe had long lov'd the youth in vain, Till love refused, converted to disdain :

Then nixing pow'rful herbs, with magic art, She chang'd his form, who could not change his heart." Dryden's Virgil. 


\title{
YOU ARE PERFECI.
}

\author{
Pixe Apple.-Ananas.
}

The difficulty of acquiring perfection is of great advantage, since it acts as a stimulus to exertion; but we may safely conclude in the words of Pope,

“Whoever thinks a perfect work to see,

Thinks what ne'er was, nor is, nor e'er shall be."

\section{YOU ARE RICH IN ATTRACTIONS.}

\author{
Garden Ranunculus.
}

"And full rammeulus, of glowing red."

Thomson.

Mortimer observes, that ranunculuses excel all flowers in the richness of their colours.

\section{"Adorn"d}

she was indeed, and lovely, to attract Thy love; not thy subjection."

Millon. 


\section{YOU ARE WITHOHOUT PRETENSION.}

Rose Campion.-Agrostemma coronaria.

The simplicity and unassuming character of this flower has procured it this honourable motto. Denham says,

"But if to unjust things thou dost pretend, Ere they begin, let thy pretensions end." 


\section{YOU FREEZE ME.}

ICe Plant.-Mesembryantheum rrystallimum.

“With fretted frost-work spangled o'cr."

This species of mesembryantheum, whose crystalized juices glitter like diamonds on the plant, giving the idea of icicles in the heat of summer, is emblematical of those cold-hearted persons whose bosoms never warm into friendship.

Lord Byron says, a lady's friendship is love full fledged, and only waiting for a fine day to fly. 


\section{YOU PLEASE ALL.}

Branchl of Currants.-Ribes.

"They butter'd currants on fat veal bestow'd, And rumps of beef with virgin honey stew'd."

This transparent fruit (which has no peculiar flavour to gratify one palate at the expense of others) seems agreeable to all, and therefore it has been selected to represent the motto, "You please all."

Overstrained attentions to one party generally bring displeasure from others. 


\title{
YOUR PRESENCESOFTENS MY PAINS.
}

\author{
MiLk-vetch.-Astragalus. \\ "The power of herbes, both which can liurt and ease, \\ And which be wont t' enrage the restlesse sleepe." \\ Spenser.
}

This emblem originated from the medicinal properties of the plant, as its name was bestowed in consequence of the quantity of milk, that it causes animals to yield which feed on it. Shakspeare says,

"The presence of a king engenders love Amongst his subjects, and his loyal friends, As it disanimates his enemies."

IIenry 4 lh. 


\title{
YOUR QUALITIES SURPASS YOUR CHARMS.
}

\author{
Mrgnonette.-Reseda Odorala. \\ " the fragrant weed, \\ The Frenchman's darling."
}

Cowper.

This odorous little plant of Egyptian sands, whose flowers are so unassuming, gave rise to the motto of "Vos qualités surpassent vos charmes," by a circumstance related in the Flora Historica. 


\section{YOU SHALL HAVE JUSTICE.}

Sweet-scenten Tussilage.-Tussilago fragrans.

"And trodden weeds send out a rich perfume."

Addison.

That a European plant of such an exquisite fragrance should have remained unknown until the nineteenth century, was sufficient to have induced M. Villan when he discovered it, to exclaim,

"On vous rendrajustice." 


\title{
YOUTH.
}

\author{
Fox-glove.-Digitalis. \\ "Explore the fox-glove's freckled bell." \\ Mrs. Charlotte Smith. \\ "Et la vermille digitale \\ Image des feux du couchant."
}

The light down which covers the stalks of this plant, induced the poets to make it the emblem of youth.

"Youth, ah stay, prolong delight,

Close thy pinions stretch'd for flight;

Youth disdaining silver hairs,

Autumn's frowns, and winter's cares,

Dwell'st thou but in dimple sleek,

In vernal smiles, and summer's cheek?

On spring's ambrosial lap thy hands unfold,

They blossom fresh with hope, and all thy touch is gold."

Lovibond. 


\title{
YOU WILL CAUSE MY DEATH.
}

\author{
HEMLOCK.-Conium.
}

“ That to which old Socrates was curs'd."

Dryden.

This deadly plant is not more to be dreaded than the insinuating arts of the deceiver.

"Quivers and bows and poison'd darts, Are only us'd by guilty hearts."

Roscommon. 


\section{ZEALOUSNESS.}

ELDER.-Sambucus.

"There the favourite elder was planted, Whose wide-extending branches, shelter'd The early plants of the rustic garden, Whilst its umbels of faint-smelling flowers Afforded them their only cosmetic, And its purple berries their only wine. Its first young buds form'd their only pickle; Its pithy stalks their children's only toy."

This native tree, which forms the dispensary of our peasantry, seems zealous in their service, for it is so tenacious of life, that it thrives not only in swampy grounds, wet ditches, arid and sterile banks, but it grows also on the ruins of old towers, and is frequently seen self-planted on the trunks of decaying trees. 


\section{ZEST.}

\section{LEMON.-Citrus Limon.}

"Bear me, Pomona,

To where the lemon and the piercing lime

With the deep orange, glowing through the green, Their lighter glories blend."

"Nor be the citron, Media's boast, unsung."

"Sharp-tasted citron Median climes produce, Bitter the rind, but gen'rous the juice;

A cordial fruit."

This fragrant plant, whose fruit imparts such an agreeable relish to the board and the bowl, we present as the emblem of zest, and should our pages give a similar zest for a novel and innocent amusement, we shall deem our labours most pleasingly rewarded. 


\section{INDEX.}

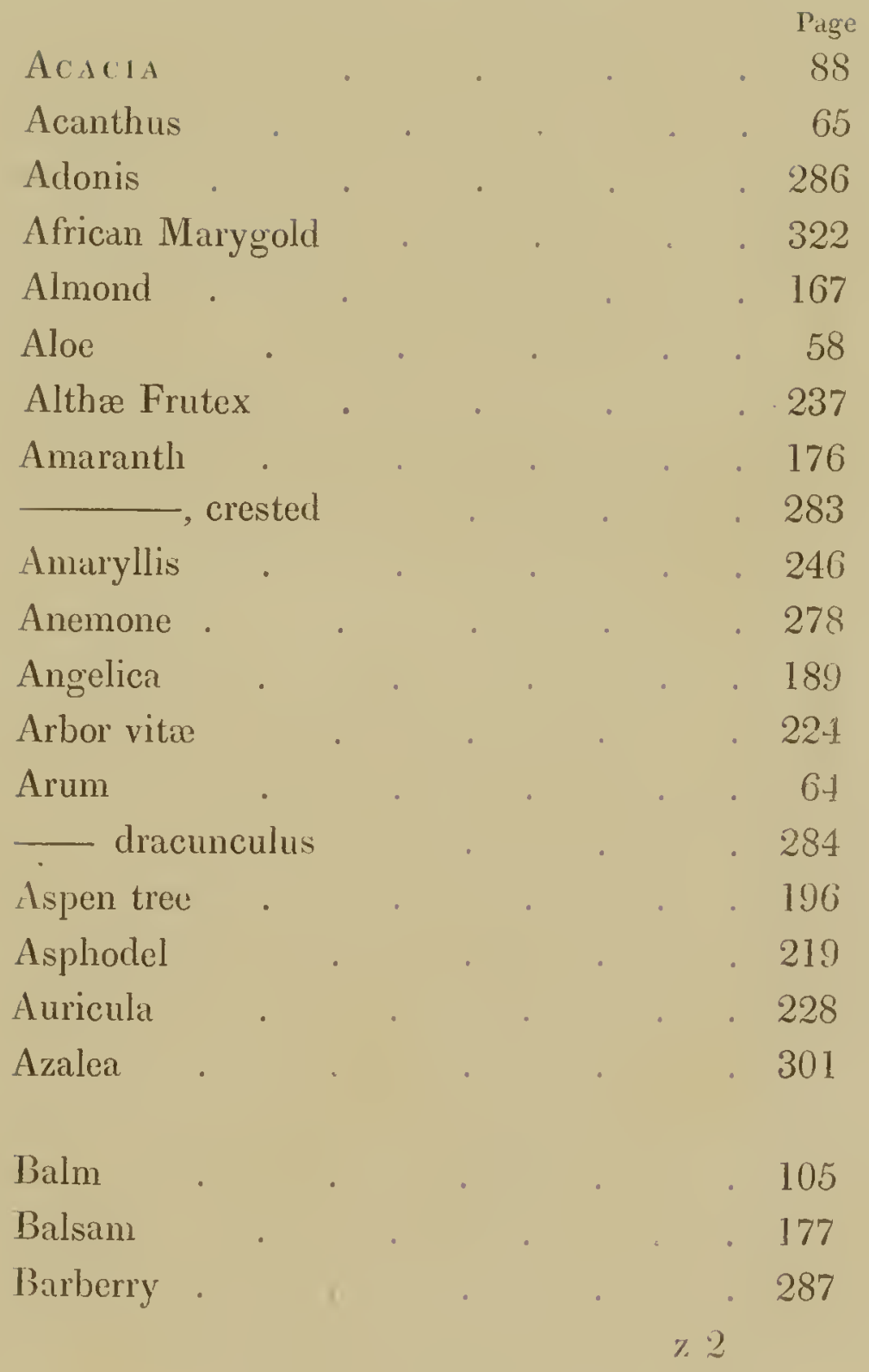


Basil

Beard

Bear's-breech

250

Beech

Bee Orchis

Betony

Bindweed

—, small . . . 223

Blackthorn . . . . 118

Bladder Senna . . . . 154

Blue Bottle . . . . 114

Borage . . . . . 79

Box . . . . . . 289

Bramble . . . . 133 and 263

Broom . . . . 172

Buckbean . . . . 84

Bugloss . . . . . 137

Butter-cups . . . 92

Butterfly Orchis . . . . 156

Cabbage . . . . . 248

Cactus Aagelliformis, . . . . 170

Opuntia . . . 174

Camellia . . . . 76

Campanula $\quad$. $\quad$. $\quad$. $\quad 99$

-—_, white . . . 164

Canary Grass . . . . 230

Candy Tuft . . . . . 63

Cardinal's Flower . . . . 123

Carnation . . . 260 
INDEX.

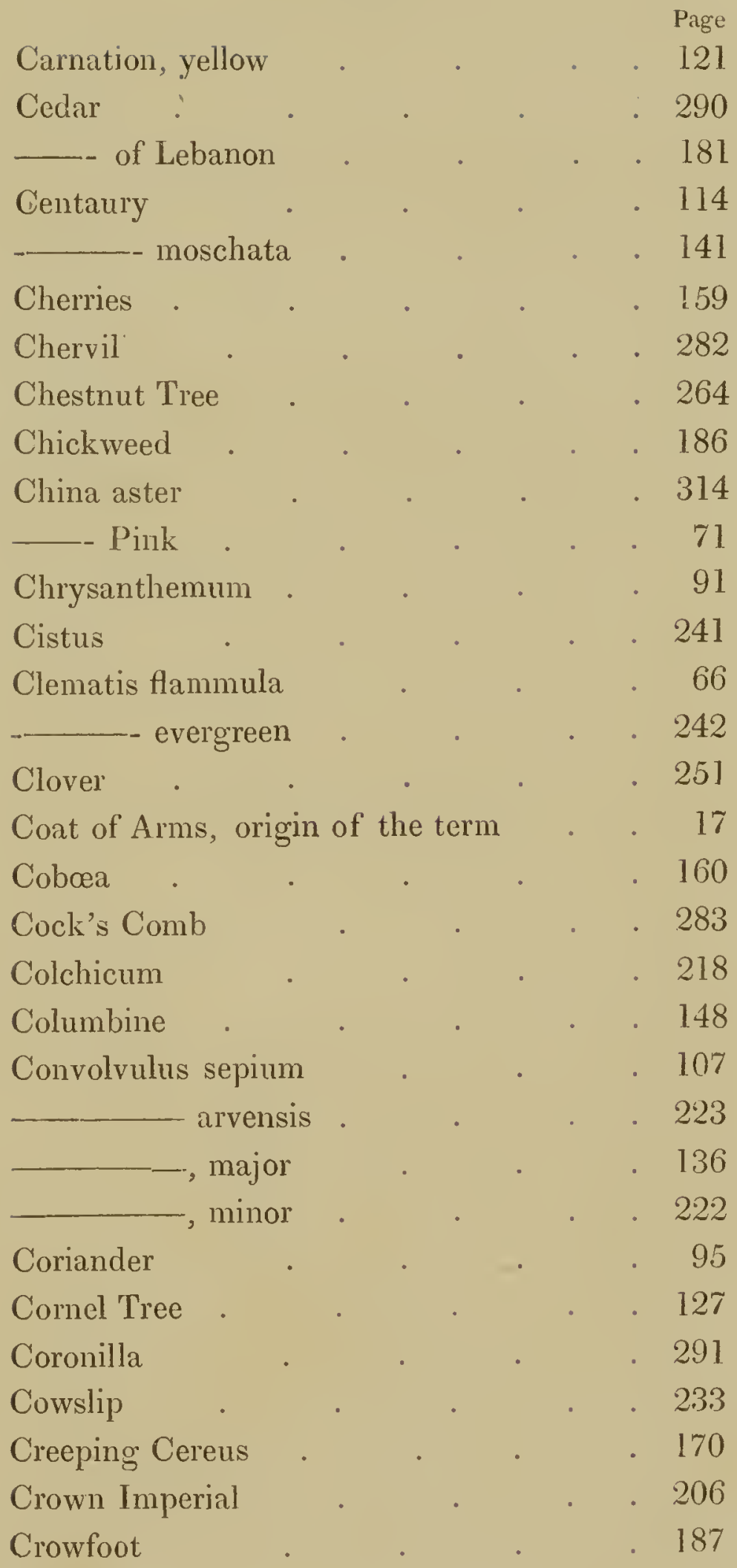


Page

Cuckoo Flower . . . 230

Cuckoo Pint . . . . 64

Currants . . . . 331

Cyclamen . . . . 119

Daffodil . . . . 111

Dahlia . . . . 190

Daisy . . . . . 188

—, double . . . . 229

Dandelion . . . . 225

Darnel . . . . 315

Day Lily . . . . . 100

Dittany . . . . 78

Dogwood . . . . 127

Dragon Plant . . . . 284

Ebony . . . . . 79

Eglantine . . . . . 281

Elder . . . 337

Emblems, the invention of . . . 3

_ , used by the Turkish ladies _ vii

$\longrightarrow$, in Scripture . . $\quad \mathrm{ix}-\mathrm{xi}$

—. Highland . . . . 13

— , numerical . . 27

- for the days of the week $\quad 29$

— , for the Calendar Months . 37

Enchanter's Night Shade ‘ . . 327

Endive . . . 155

Evening Primrose . . . . 180

Everlasting . . . . 221

Everlasting Pea . . . . 198 
INDEX.

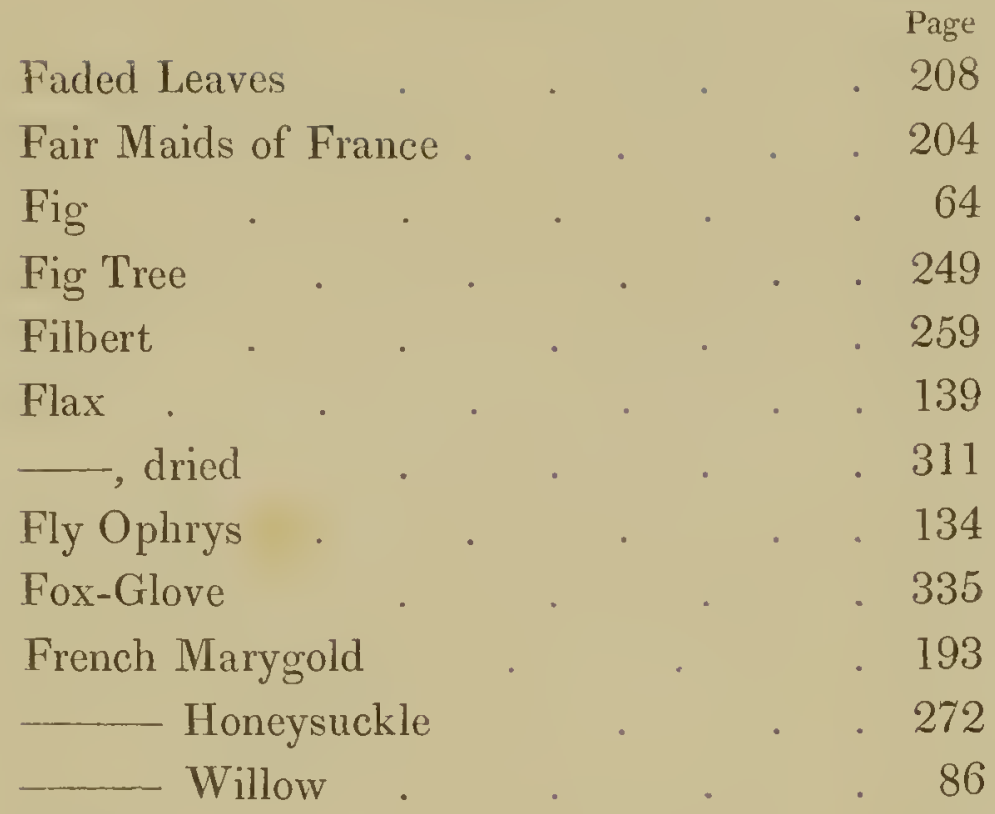

Fritillary . . . . . 236

Frog Ophrys . . . . 122

Fuchsia . . . . . 299

Fullers' Teasel . . 70 and 90

Fumitary . . . . . . 288

Genista . . . . 220

Gentian Yellow . . . 187

Geranium . . . . 244

Goat's Rue . . . . . 258

Golden Rod . . . . 243

Goldy Locks . . . . . 298

Good Henry . . . . 160

Grammar of Floral Emblems . . 24

Guelder Rose . . . . . 325

Hawkweed . . . . . 256

Hawthorn . . . . . 169

Heart's Ease . . . . 302 
INUEY.

Heath

Helenium

Heliotrope

Hemlock

Henbane

Hepatica

178

Heraldry, antiquity of

11 and 17

Hieroglyphics, the first written Language . 1

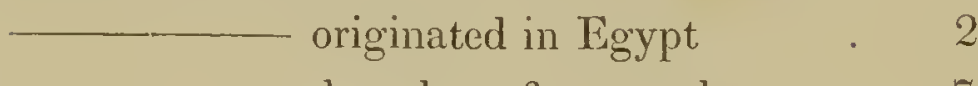

Hollyhock . . . . 141

Honesty . . . . 168

Honeysuckle . . . . $\quad$. 83

Hop . . . . . . . 188

Hornbeam . . . . . 226

Horse Chestnut . . . . 205

Houseleek . . . . . 317

Hoya . . . . 273

Hyacinth . . . . . . 238

Hydrangea . . . 81

Ice Plant . . . . 330

Indian Fig . . . . . 174

— Pink . . . . 71

Ipomøa . . . . . 70

Iris . . $\quad 132$ and 212

--, yellow . . . . 146

Ivy . . . . . 144

Jasmine, common . . 62 


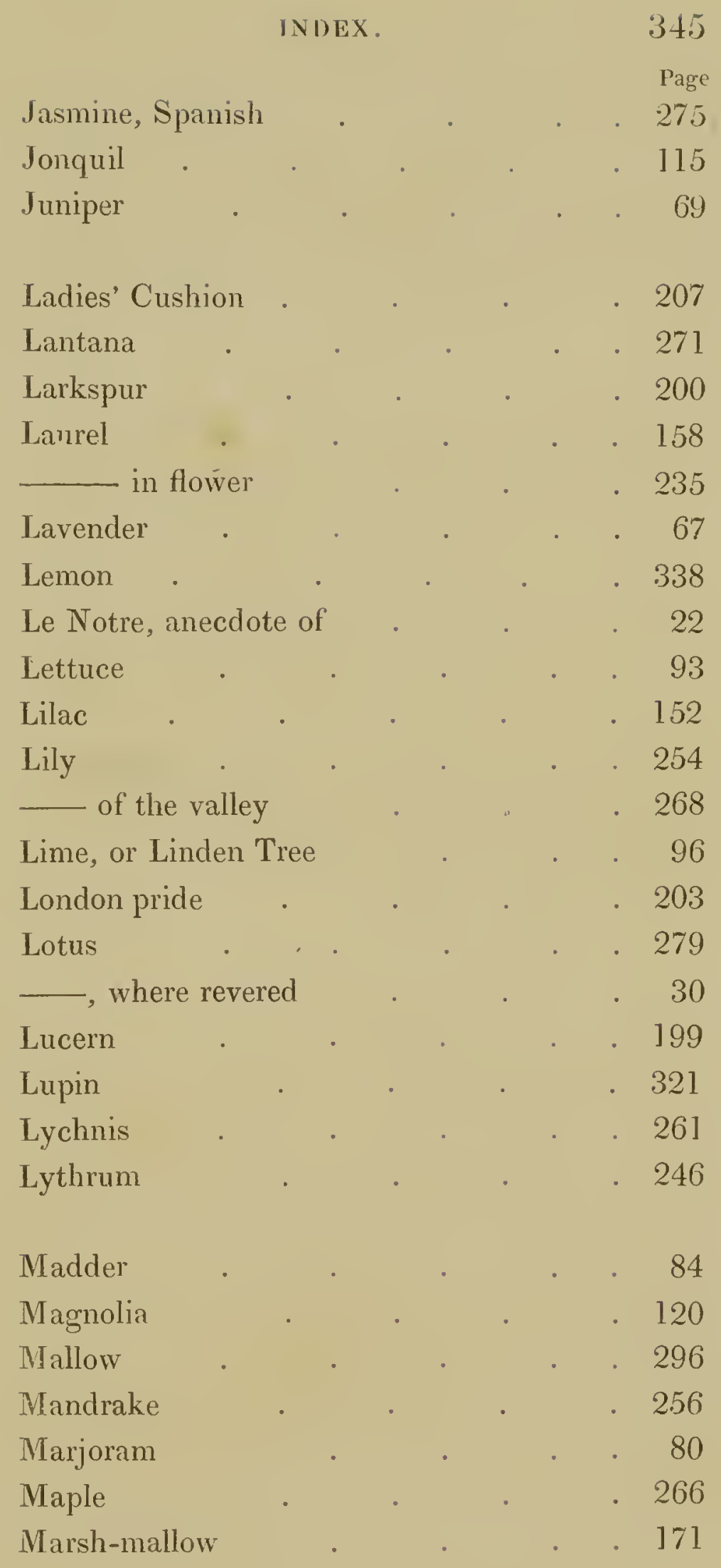


INDEX .

Marvel of Peru

Marygold

117 and 308

Mercury

- 160

Mesembryanthemum

175

Mezereon

- 116

Michaelmas Daisy

Mignonette

333

Milfoil

Milk-vetch

324

Mint

332

Misseltoe

317

Monkshood

227

Moschatell

195

Mountain Ash

324

Moving Plant

253

Mulberry Tree

60

Mullen

326

Mushroom

159

Myosotis

295 and 309

Myrtle

151

202

Narcissus

129

Nasturtium, scarlet

287

Nightshade

306

Numerical Emblems

27

Nymphæa

- 279

Oak

170

Olive

232

Orange Flowers

- Tree

157

Osier

153 


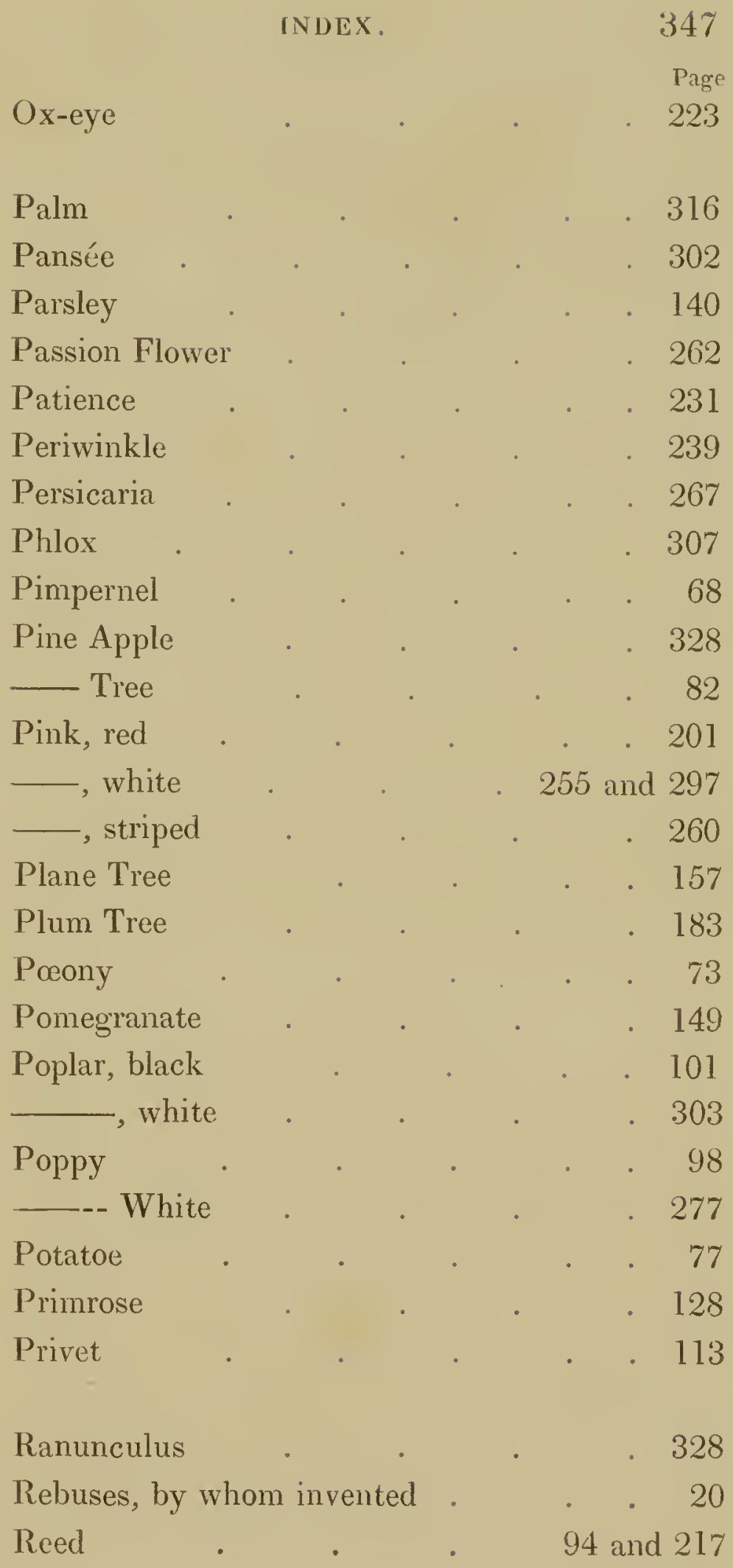


INDEX .

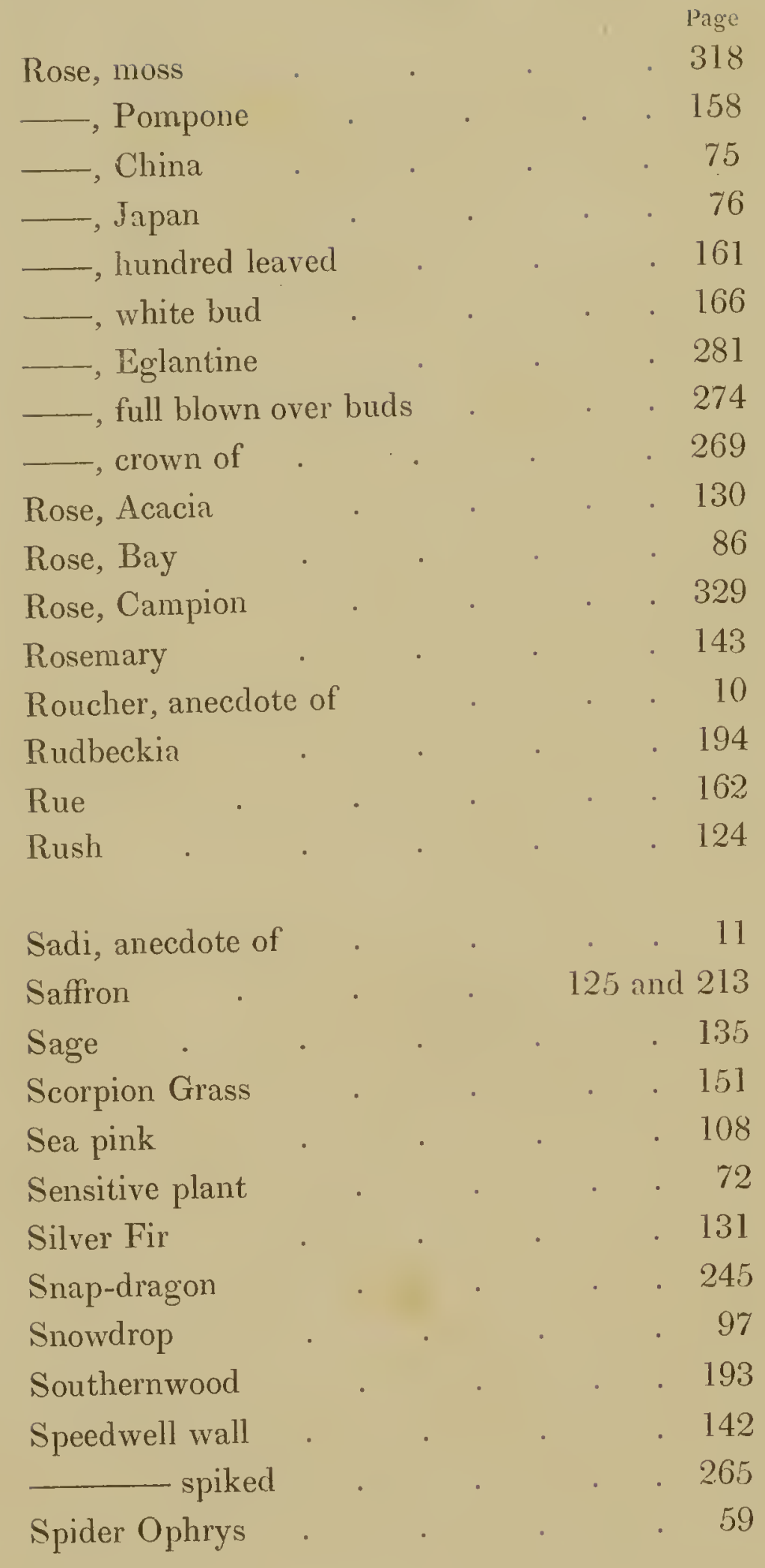


INDEX .

Spirœ Hypericum

St. John's Wort . . . . . 293

Star Wort . $\quad$. $\quad$. 59

Stock . . . 197

, ten weeks . . . 250

Stinging-nettle . . . . 104

Strawberry . . . . 234

Stramonium . . . . 110

Squirting Cucumber $\quad$. 103

Sun-flower . . . . 138

Sweet-briar . . . 240

- Scabious . . . 324

\begin{tabular}{|c|}
\hline $\begin{array}{l}\text { William } \\
\text { Pea }\end{array}$ \\
\hline Sultan \\
\hline Swallow-wort \\
\hline Syringa \\
\hline
\end{tabular}

Tamarisk . . . 102

Tansy . . . . 267

Thistle . . . . 179

Thorns, branch of . . . 277

Thrift . . . . 108

Thyme . . . . $\quad 57$

Trefoile . . . . . 252

Trumpet flower . . . . 276

Tuberose . . . . . 319

Tulip . . . . . 112

Turnip . . . . $\quad 87$

Tussilage $\quad$ • $\quad$ • $\quad 334$ 
INDEX.

\begin{tabular}{|c|c|}
\hline Rhododendron & \\
\hline Rose . & \\
\hline —, white & \\
\hline —, yellow & . \\
\hline __, damask & \\
\hline —, musk & . \\
\hline Valerian & . \\
\hline —_, Greek . & . \\
\hline Venus's Looking-glass & . \\
\hline Vervian . & . \\
\hline Vine & . \\
\hline Violet & . \\
\hline __-, white & 85 and \\
\hline Virginian Spider wort & . \\
\hline Wall flower & . \\
\hline Water Lily & . \\
\hline Water Melon & . \\
\hline Weeping Willow & . \\
\hline Wheat & . \\
\hline Whortle-berry & . \\
\hline Winter Cherry & . \\
\hline Woodbine & . \\
\hline Wormwood & \\
\hline Yarrow & . \\
\hline Zealousness & \\
\hline Zest & \\
\hline
\end{tabular}




\title{
DIRECTIONS
}

\author{
FOR
}

\section{PLACING THE PLATES.}

Plate

1. The Shield of Floral Emblems to form the Title Page.

2. The Emblematical Design for the DediCATION to follow.

3. The British Ewer, with the Symizol of His Majestry's Birth-Day; to face the Introduction.*

4. The Numerical Leaflets - lo face 27

5. The Seven Leaves for the Days of The

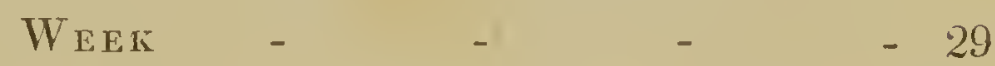

6. The EMblems for JANUARY, FEBRUARY, and $\begin{array}{llllll}\mathrm{MARCH} & - & & & & \end{array}$

7. ApriL, MAY, and JUNE - - - 41

8. July, August, and September - - 45

9. October, November, and December - 48

* By an error in the drawing the date of the year on the Ewer, it has been made to read from the right to the left. If held to a looking-glass it will appear correct. 
Plate Page

10. Youtil and BEAUTy united by the Bonds of

Love $\quad$ - $\quad$ - $\quad$ - $\quad$ to fuce 83

11. DANGER accompanying COQUETRY - $\quad-100$

12. DeClaration of Love $\quad$ - $\quad$ - $\quad 112$

13. Desire not Popular Favoul _ - $\quad 123$

14. Folly and ERror $\quad$ - $\quad$ - $\quad$ E

15. The Bowl of Hospitality -

16. Delicate and Lasting Plensures - - 188

17. Hope separated from LovE - $\quad-\quad-246$

18. Pensiveness arising from Solitude - $\quad 285$

19. Consolation arising from Thoughts - 302

20. Ideness, Voluptudousfiss, \&c. - - 319 
n

$-1-2$

nen 



CORNELL UNIVERSITY DEPT. OF PRESERVATION \& CONSERVATION

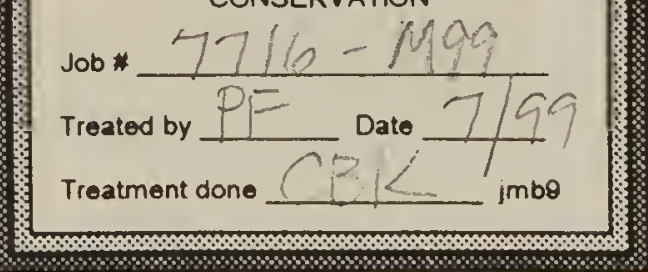


